\title{
Oregon: A Guide to Geothermal Energy Development
}

\author{
Prepared for
}

\section{U.S. Department of Energy (USDOE) \\ Region X Office \\ Seattle, Washington}

\author{
Contract No. EY-77-C-06-1066 \\ by \\ Debra Justus \\ Neil Basescu \\ R. Gordon Bloomquist \\ Charles Higbee \\ Stuart Simpson \\ Geo-Heat Utilization Center \\ June, 1980
}




\section{DISCLAIMER}

This report was prepared as an account of work sponsored by an agency of the United States Government. Neither the United States Government nor any agency Thereof, nor any of their employees, makes any warranty, express or implied, or assumes any legal liability or responsibility for the accuracy, completeness, or usefulness of any information, apparatus, product, or process disclosed, or represents that its use would not infringe privately owned rights. Reference herein to any specific commercial product, process, or service by trade name, trademark, manufacturer, or otherwise does not necessarily constitute or imply its endorsement, recommendation, or favoring by the United States Government or any agency thereof. The views and opinions of authors expressed herein do not necessarily state or reflect those of the United States Government or any agency thereof. 


\section{DISCLAIMER}

Portions of this document may be illegible in electronic image products. Images are produced from the best available original document. 


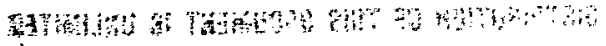




\section{ACKNOWLEDGEMENTS}

This guide to geothermal energy development reflects the work of many individuals and groups and could not have been completed without their full cooperation and support.

The authors would like to express their appreciation and give special recognition to Dave Anderson and John Lund for allowing the authors free use of the materials developed for the Geothermal Resources Council publication "Direct Utilization of Geothermal Energy - A Technical Handbook."

Special appreciation is expressed to Eric Schuster and Mike Korosec for technical review of the Exploration chapter and the Glossary, Walter Youngquist for review of the Drilling chapter, and to Colleen Fry for editing the many drafts of the entire report.

Our thanks to the following individuals for review of the Legal and Institutional chapter: Roald Bendixen, Vern Newton, Charles Ashbaker, Eliot Allen, Bill Sanderson, Leonard Wilkerson, Peter Paquet, Joe Riccio, Jack Fuerer, William Isherwood, Tom Wilson and David Philbrick.

Our special thanks to Gibb Johnson and Ramesh Venkajakrishnan of the University of Idaho Cartographics Department for the excellent diagrams and artist's sketches found throughout the report and including the front cover.

To June Hecht, without whose dedication to the preparation of the manuscript we would never have completed this report on time, our special appreciation. 


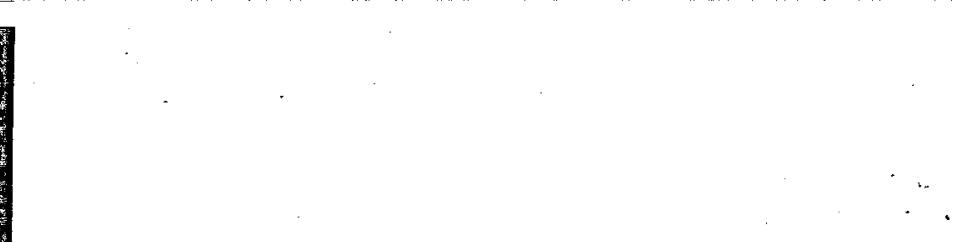

0 
METRIC/ENGLISH CONVERSIONS

$$
\begin{aligned}
& 1 \mathrm{~m}^{3}=35.3 \mathrm{ft}^{3}=264 \mathrm{gals} \\
& 1 \text { meter }=3.281 \mathrm{ft} \\
& 1 \text { kilogram }=2.21 \mathrm{~b} \\
& 1 \text { liter }=0.264 \mathrm{gal}=0.0353 \mathrm{ft}^{3} \\
& 1 \text { liter } / \mathrm{sec}=.001 \mathrm{~m}^{3} / \mathrm{sec}=15.8 \mathrm{gpm} \\
& 1 \text { joule }=0.000948 \mathrm{Btu} \\
& 1^{\circ} \mathrm{C}=\left(\mathrm{OF}-32^{\circ}\right) \times 5 / 9 \\
& 1 \mathrm{~m}^{2}=10.76 \mathrm{ft}^{2}
\end{aligned}
$$

\begin{tabular}{|c|c|c|c|c|c|}
\hline $\begin{array}{c}\text { British Thermal } \\
\text { Units } \\
\text { (Btu) }\end{array}$ & $\begin{array}{l}\text { Cubic Feet } \\
\text { Natura? Gas } \\
\text { (CF) }\end{array}$ & $\begin{array}{l}\text { Kilowatt Hours } \\
\text { Electricity } \\
\text { (kwh) }\end{array}$ & $\begin{array}{c}\text { Barrels of } 0 i 1 \\
\text { (bbl) }\end{array}$ & $\begin{array}{l}\text { Short Tons } \\
\text { Bituminous Coal } \\
(T)\end{array}$ & $\begin{array}{c}\text { Tons of } \\
\text { Refrigeration }\end{array}$ \\
\hline $\begin{array}{c}1 \\
1000 \\
3413 \\
1 \text { Million } \\
3.41 \text { Million } \\
5.6 \text { Million } \\
25 \text { Million } \\
1 \text { Quadrillion } \\
\text { (Quad) (Q) }\end{array}$ & $\begin{array}{c}0.001 \\
1 \\
3.41 \\
1000 \text { ( } 1 \mathrm{MCF}) \\
3413 \\
5600 \\
25,000 \\
1 \text { Trition } \\
\text { (1 TCF) }\end{array}$ & $\begin{array}{c}0.000293 \\
0.293 \\
1 \\
293 \\
1000 \text { ( } 1 \text { MWh) } \\
1640 \\
7325 \\
293 \text { Billion }\end{array}$ & $\begin{array}{c}0 . \overline{-}- \\
0.0018 \\
0.0061 \\
0.18 \\
0.61 \\
1 \\
4.46 \\
180 \text { Million }\end{array}$ & $\begin{array}{c}0.0004 \\
0.00014 \\
0.04 \\
0.14 \\
0.22 \\
1 \\
40 \text { Million }\end{array}$ & $\begin{array}{c}-\overline{-} \\
.0833 \\
.284 \\
83.3 \\
284 \\
466 \\
2083 \\
83.3 \text { Billion }\end{array}$ \\
\hline
\end{tabular}

NOMINAL FUEL HEATING VALUES

1 cubic foot natural gas $=1000 \mathrm{Btu}$

1 pound bituminous coal $=12,500 \mathrm{Btu}$

1 gal \#2 fuel oil $=1.42 \times 10^{5} \mathrm{Btu}$

1 Therm $=10^{5} \mathrm{Btu}$

1 barrel crude 0 il $=5.6$ million Btu

\section{ENERGY UNIT CONVERSION CHART (100\% Efficiency)}

*Defined as the heat of fusion of one ton of water, equal to 288,000 Btus 
Acknowledgements. . . . . . . . . . . . . . . . . . i i i Conversion Factors. . . . . . . . . . . . . . . . . . . v Introduction. . . . . . . . . . . . . . . . . . . . . i

CHAPTER I - OREGON'S GEOTHERMAL POTENTIAL . . . . . . . . . . 5

CHAPTER II - EXPLORATION. . . . . . . . . . . . . . . . 11

I. Geological Methods. ................. 12

II. Geochemical Methods . . . . . . . . . . . . 14

III. Geophysical Methods . . . . . . . . . . . . . . 15

A. Structural Methods................. 15

B. Electrical and Electromagnetic Methods. . . . . . . 16

C. Passive Seismic Methods . . . . . . . . . . . . 16

IV. Exploration Costs .................. 17

Selected References . . . . . . . . . . . . 18

CHAPTER III - ORILLING. . . . . . . . . . . . . . . 21

I. Drilling Preparation. . . . . . . . . . . . . 21

A. Road Construction .............. 22

B. Drill Pad Construction.............. 22

C. Drilling Sump Contruction ............. 22

D. Typical Equipment ............... 22

E. Personnel ................. 24

II. Drilling. . . . . . . . . . . . . . . . 24

A. Bore Diameter . . . . . . . . . . . . . 24

B. Rig Types . . . . . . . . . . . . . . 25

C. Directional Drilling. . . . . . . . . . . . 28

D. Blowout Prevention.............. 28

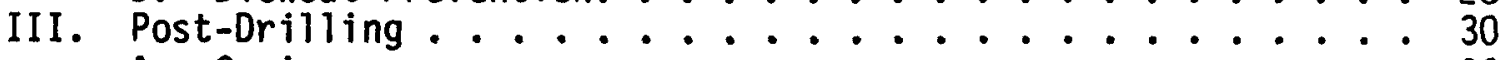

A. Casing. . . . . . . . . . . . . . 30

B. Testing the Wel1................. 31

C. Abandonment................. 31

Selected References . . . . . . . . . . . . . 33 
CHAPTER IV - UTILIZATION. ............... 35

I. Electrical Generation............... 35

A. Dry Steam Plants. . . . . . . . . . 37

B. Flashed Steam Plants. ........... 38

C. Binary Plants ................... 39

D. Hybrid Plants ....................... 41

II. Direct Utilization. ..............41

A. Industrial Processing ............. 43

B. Space Conditioning. . . . . . ......44 43

C. Agriculture and Aquaculture ........... 46

III. Indirect Utilization. .............. 48

A. Auxiliary Boilers............... 48

B. Heat Recovery Systems - Heat Pumps. . . . . ... 49

Selected References . . . . . . . . . . . . 50

CHAPTER $V$ - ECONOMIC FACTORS OF DIRECT USE PROJECTS . . . . . . 53

CHAPTER VI - LEgAL AND INSTITUTIONAL SETTING. ........ 63

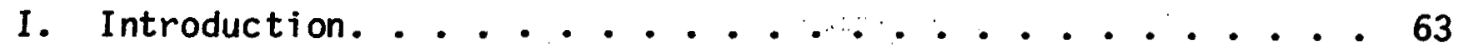

II. Obtaining Access to Geothermal Resources. . . . . . . 63

A. Determining Resource Ownership. . ..........63

B. Access and Development Rights ......... 64

III. Exploration and Development Regulations ........ 76

A. Private Lands ................ 77

B. State Lands ................ 77

C. Federal Lands ................ . . 77

D. Oregon Wel1 Permitting Procedures . . . . . . . 82

E. Geothermal Fluid Disposal ............ 85

F. Water Rights. . . . . . . . . . . . 86

G. Facility Siting .............. 87

IV. Distribution and Use. .............. 88

V. Information, Assistance and Incentives. ........ 89

A. Information Sources . . . . . . . . . . 89

B. Technical Assistance. . . . . . . . . . . . 91

C. Funding Opportunities ............. 91

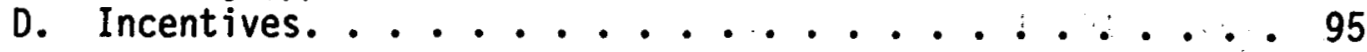

Selected References................ . 97

SELECTED REFERENCES . . . . . . . . . . . . . . 99

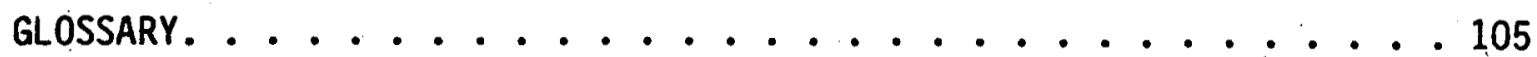




\section{FIGURES}

Figure

Page

1 Oregon Regional Profiles.............. 4

2 Cross Section of a Geothermal System .......... 11

3 Temperature Versus Depth for Various Gradients . . . . . . . 14

4a Simplified View of Typical Drilling Sites. ........ 23

4b Typical Rotary Drilling Rig and Mud Circulation Arrangements 23

5 Typical Blowout Prevention Equipment . . . . . . . 29

6 Typical Casing Program for a Production Well . . . . . 30

7 Direct Thermal Application of Geothermal Energy. . . . . . 36

8 Dry Steam Power Plant. ............ 37

9 Flash Steam Power Plant............. 38

10 Double Flash Power Plant ............. 39

11 Binary Cycle Power Plant .............. 40

12 Temperatures Required for Various Direct

Geothermal Applications............. 42

13 Space Heating and Cooling with Geothermal Fluids ...... 43

14 Typical Downhole Heat Exchanger Installation . . . . . . 44

15 Typical Heat Convectors and Heat Pump. . . . . . . . . 45

16 Agricultural Uses for Geothermal Resources . . . . . . 47

17 Heat Recovery System . . . . . . . . . . . . . 48

18 Total Annual Costs of Conventional Fuel vs. Direct-Use Geothermal . . . . . . . . . . . 57

19 Oregon Geothermal Lease Application.......... 68

20 Federal Geothermal Regulatory Process. . . . . . . . 70

21 Application to Lease Geothermal Resources. . . . . . . . . 73

22 Geothermal Regulatory Process Pre-Lease Activities . . . . 75

23 Federal Geothermal Regulatory Process Principal Post-Lease Activities . . . . . . . . . 78

24 Geothermal Regulatory Process Post Lease Activities . . . . . . . . . . . . 80

25 General Stipulations Which Apply to Geothermal Drilling Permits............. 84 


\section{TABLES}

Table

Page

I Costs of Exploration Activities. . . . . . . . 17

II Worldwide Geothermal Electrical Generating Capacity. . . . 35

III Basics of Economic Analysis. . . . . . . . . . 55

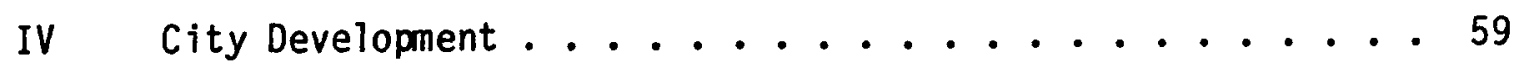

V Geothermal Development Corporation ......... 60 
$x i j$

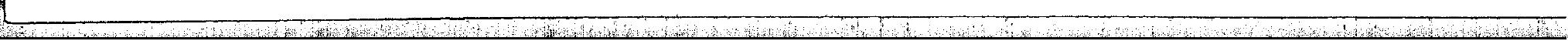


The Resource

Of the earth's total volume of more than one trillion cubic kilometers, all but a relatively thin crust averaging about 30 kilometers thick is very hot. It is believed that the sources of this tremendous amount of heat are radioactivity and friction deep within the earth. In regions where the crust is particularly thin, the heat of the earth may be manifested in hot springs, fumaroles, geysers, and, most dramatically, volcanoes. In recent years the theory of plate tectonics has served as a structure for understanding these phenomena, vital to the successful exploration for and development of the earth's vast geothermal resources.

As with any underground resource, the cost and feasibility of recovery of geothermal energy is directly related its depth. Along the borders of tectonic plates and in zones of crustal extension such as the basin and range provinces of the western United States, the earth's interior heat reaches close to the surface, offering the possibility of economical energy recovery. Perhaps the cost of geothermal energy utilizations is best viewed as a function of the "geothermal gradient", which is the rate at which temperature increases with depth. Where the geothermal gradient is high, temperatures increase rapidly with depth. The average geothermal gradient is about $25^{\circ} \mathrm{C}$ per kilometer.

There are several types of geothermal resources. Virtually all of the world's current utilization involves hydrothermal convection systems, wherein naturally occurring ground water is heated at depth. Systems may be either vapor dominated (steam) or hot water dominated, depending of course on temperature and pressure. The three essential ingredients of a hydrothermal system are a sufficient heat source, an aquifer with an adequate supply of groun dwater, and an impermeable stratum overlying the aquifer. Other types of geothermal resources include hot dry rock, which requires the injection of water to be used as a heat transfer medium, and geopressured zones, in which water is trapped together with natural gas under thousands of feet of sediments.

The Uses

Naturally, the use of a geothermal resource depends upon both the nature of the resource itself and the energy demand around it. Utilization is commonly divided into two basic categories; electricity generation, usually requiring temperatures of $150^{\circ} \mathrm{C}$ or more, and direct applications, such as space heating for homes and businesses, applications in agriculture and aquaculture, various industrial process heating uses, and recreational use in pools and hot tubs. An estimated $1800 \mathrm{MWe}$ (equivalent to roughly 27 million barrels of oil per year) is presently generated in the world, nearly half of which comes from The Geysers in northern California, the United States' only geothermal power generation site. The resource accounts for an additional $7000 \mathrm{MWt}$ on-line worldwide (equivalent to roughly 35 million barrels of oil per year), only $100 \mathrm{MW}$ thermal of which is in the United States. 
Development of a potential geothermal resource involves the coordinated efforts of geologists, economists, and engineers, as well as legal counsel to deal with permitting procedures and environmental regulations. Exploration begins with an analys is of surface expressior.s such as hot springs and hydrothermal alteration. The next step in a ifining a resource is detailed geologic mapping (i.e., 1:24,000). Based on the se results, a program of geophysical exploration is devised involving or - or several of the following techniques: magnetic, infrared, and gravity surveys; resistivity testing; and active and passive seismic exploration. If the results of this work are encouraging, several relatively shallow (300600 meters) exploratory holes are drilled to measure the geological gradient and heat flow. Finally one or more deep exploration wells are drilled.

The cost of producing electricity with geothermal energy varies considerably according to the resource parameters and the type of generating facility used: Optimally, geothermal power can be produced for as little as $2.5-3 \notin / \mathrm{kwh}$ from dry steam (binary systems cost $4-5 \$ / \mathrm{kwh}$ ) as compared to $6.5 \mathrm{k} / \mathrm{kwh}$ for a coal-fired plant brought on-line in 1984 and 7.3 $\$ /$ kwh for an oil-fired plant operating at 60 percent capacity.

In view of the magnitude of the earth's recoverable geothermal resources, a rapid increase in their utilization is anticipated for the coming years. The mounting concern in America over soaring world oil prices and the health and environmental problems associated with its own vast coal and nuclear reserves, has precipitated a great interest in energy alternatives. Geothermal energy, particularly in the western states, has the potential to contribute significantly to the replacement of those conventional fuels at a cost both economically and environmentally affordable. 
Blank

$-3-$ 


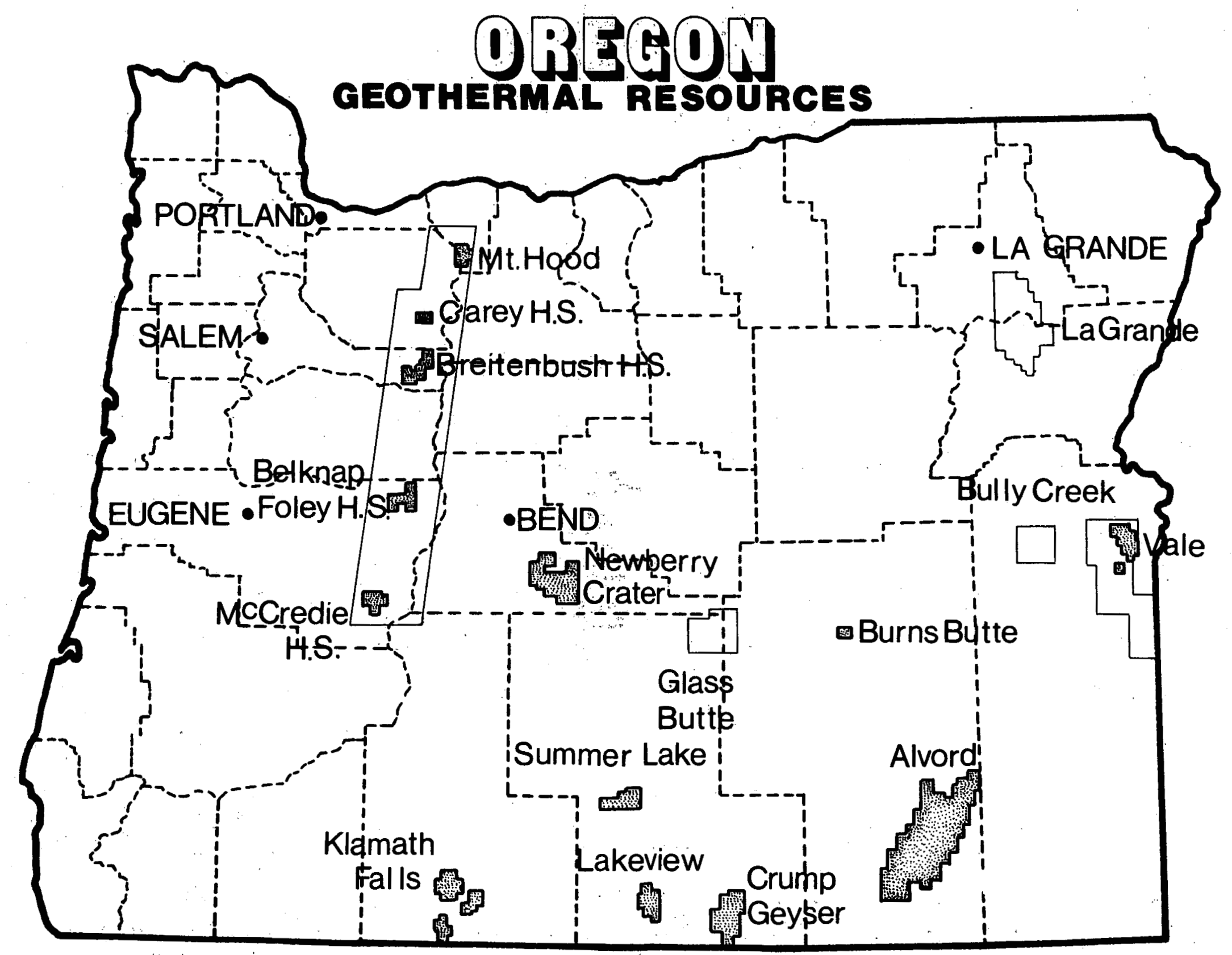

WKanA Known Geothermal Resource Area $\square$ PGRA Potential Geothermal Resource Area 
Oregon's major geothermal areas hold considerable untapped potential for beneficial use of the earth's heat. There is much to be discovered about the nature and occurrence of geothermal resources and Oregon's resource potential has not been fully defined. However, the indications are favorable that geothermal resources can play a significant role in Oregon's energy future if resource assessment and development activities occur in a timely manner.

Oregonians have been using geothermal energy for many years but less than one percent of the energy potential has been tapped. In Klamath Falls, energy extracted from hot water wells for space and water heating equals approximately 60 megawatts thermal $\left(\mathrm{MW}_{\mathrm{t}}\right)$ during peak periods. Other space heating applications around the state contribute about one $M W_{t}$ to current geothermal energy consumption. Successful development of a municipal heating district in Klamath Falls, the first phase of which will be complete in 1981, will greatly increase geothermal's contribution to Oregon's energy supply.

Interest in the development of geothermal energy resources is increasing and state and federal tax credits and other incentives are available to encourage the use of geothermal energy. Communities are investigating local geothermal resources to determine the potential for district heating and industrial processing. Homeowners and businesses are drilling hot water wells to help supply their energy needs.

On a broader scale, interest in resource development has been expressed through the federal leasing process. More than half of the land in Oregon is in federal ownership and the majority of the state's identified resources is within this landhold. More than 431,000 acres have been classified by the U.S. Geological Survey as Known Geothermal Resource Areas (KGRA) and theoretically are available for leasing on a competitive basis. Unfortunately, geothermal exploration and development has been a low priority for the U.S. Forest Service and a majority of lands under the ir management has not been made available for leasing. Nevertheless, more than 260,000 acres have been leased for geothermal resources on both a competitive and noncompetitive basis, primarily for lands managed by the BLM. (Leases and lease applications on Forest Service land have been mapped by the Oregon Institute of Technology and the maps are available for review at the Oregon Department of Energy.)

Interest in geothermal development is also evidenced by efforts by industry, government and academic researchers to investigate Oregon's geothermal resource potential. Private companies are conducting exploration activities in the Glass Butte area, Bully Creek area near Vale, Alvord Valley, Lakeview, Crump Springs, and the Cascades. 
The majority of resource assessment activities has been conducted by the Oregon Department of Geology and Mineral Industries and the U.S. Geological Survey. The largest research efforts have focused on the ident ification of low-to-moderate temperature geothermal areas -- Mount Hood and a regional Cascade Range geothermal assessment program. Several reports on these efforts have been published and others will be forthcoming as resource assessment activities continue.

Two recent publications by the Oregon Department of Geoloyy i id Mineral Industries, Preliminary Geothermal Resource Map of Oregon and Low-to-Intermediate Temperature Thermal Springs and We TTs in Oregon, are excellent references for determining potential resource areas in the state.

These areas in Oregon range from the Cascades east across the state (Figure 1). Those regions having high potential include the Cascade Mountains, Basin and Range, High Lava Plains, Western Snakè River Plain and Northeastern Oregon.

\section{Cascade Mountains}

The Oregon Cascade Range is divided into two distinctive belts: the Western Cascades and the High Cascades. "The geologic structure and recent volcanic activity of both areas indicate potential geothermal reserves.

The High Cascades, which 1 ie to the east, comprise young volcanic rocks which show $1 \mathrm{ittle}$ evidence of erosion or deformation. Several glaciated volcanic peaks dominate the High Cascades, including Mount Hood, the highest peak in Oregon.

Unlike the younger volcanics of the High Cascades, the Western Cascades rock units generally show the effects of folding and faulting. The major hot springs of the Western Cascades are aligned in a relatively narrow zone nearly parallel to the axis of the range. The alignment of the springs may be controlled by a north trending fault. This series of hot springs all flow from structurally deformed volcanic strata of the Tertiary Western Cascade Group. The major thermal springs systems are, from north to south: Carey, Breitenbush, Belknap, Foley, and McCredie. Each of these hot spring areas has been classified by the U.S. Geological Survey as known Geothermal Resource Areas (KGRA).

Development potential in the Cascade Mountains is difficult to assess. Estimated resource temperatures in the moderate range are suitable for direct applications, but these forested areas are sparsely populated. However, the resource areas are within $a^{\prime} 60-160 \mathrm{~km}$ range from the major population centers of the Willamette Valley. Economic factors will play a decisive role in determining the feasibility of transporting geothermal energy to help meet this large energy demand, once the resources have been proven. In the near-term geothermal resources offer excellent potential for space heating facilities such as Timberline Lodge at Mount Hood. 
The electrical generation capabilities of Cascade geothermal resources are even more difficult to forecast. The geologic setting, geochemical estimates of reservoir temperature, and geothermal gradients measured during shallow exploration drilling, all provide favorable indications of geothermal resources. As well, the recent impressive display of volcanic activity at $M t$. St. Helens in Washington demonstrates the existence of thermal resources beneath one of the Cascade's major stratovolcanoes. Nevertheless, until resource characteristics are better defined, it is premature to discuss the development potential of the region's geothermal resources for electrical generation. Current resource assessment programs should help clarify the Cascade's geothermal potential in the near future.

\section{Basin and Range Province}

The Basin and Range area of Oregon extends across the southern portion of the state from the southern Cascades east to the Owyhee Upland. The area is a small portion of the vast Basin and Range Province covering parts of Nevada, California, Arizona and New Mexico.

The area is characterized by generally north-trending narrow ridges separated by basins of various size. Many of the the ranges are steep on one side and gently sloped on the other as a result of block faulting and tilting. Faulting has played a major role in the appearance of present landforms, and, in some areas, has provided a conduit for surface expressions of geothermal resources. Numerous hot springs are found throughout the region.

Potential markets for direct geothermal applications vary considerably throughout the region in relation to existing energy demands. Population concentrations range from the 11 residents of the largest community in the Alvord Valley to the densely inhabited Klamath Falls area. The only communities with populations in excess of 500 people are Lakeview and the Klamath Falls metropolitan area.

Homes and businesses in Lakeview and $K l$ amath Falls have benefitted from geothermal energy for years. Klamath Falls has the largest concentration of direct use geothermal applications in the United States. The potential in the Klamath area has barely been tapped, however.

The region has outstanding potential for development of its indigenous geothermal resources. The possibility of temperatures sufficiently hot for electric power production remains an unanswered question. Exploration activities are underway in the Warner and Alvord Valleys to determine resource capabilities for power production. Nevertheless, there is high probability of geothermal development for direct use applications in the commercial, industrial and residential sectors, particularly in Klamath Falls and Lakeview. 
The U.S. Geological Survey has classified five areas within the region as KGRAs: Klamath Falls, Lakeview, Sumer Lake, Crump Springs, and Alvord Valley. Each KRGA is situated in a basin and is associated with a thermal spring area.

High Lava Plains

The High Lava Plains extend from the foot of the Cascade Mou'tains to the eastern border of the Harney Basin. The province is an uplitted region of young lava flows marked with surface volcanic features sliun as cinder cones, craters, and lava buttes. Newberry Crater, a broad shield volcano with a summit caldera containing two large lakes and hot springs, is a prominent feature on the landscape. Overall, the region is the youngest and least eroded areas in Oregon.

The Brothers fault zone is a major structural lineament described by Peterson and others (1976) as a northwest-trending belt of en echelon normal faults extending about $300 \mathrm{~km}$ across the High Lava Plains region. It forms the northern boundary of the Basin and Range physiograptic province.

A considerable amount of geologic and geophysical data provide evidence of geothermal resource potential in the vicinity of the Brothers fault zone. Of particular note is the Heat Flow. Study of the Brothers Fault Zone conducted by the Oregon Department of Geology and Mineral

Industries. As a result of the study, three areas with promising resource development potential were identified: Harney Basin, Glass Butte, and Newberry Volcano.

Numerous hot springs and we $11 \mathrm{~s}$ in the Harney Basin, in association with young silicic rocks and other recent violcanic features throughout the region, give indications of likely thermal resources at depth. : The presence for several years of private companies conducting exploration programs lends further credence to the geothermal resource potential of the area.

Yet, resource data are inadequate to define the potential for geothermal electrical generation. A wide range of direct applications would be feasible based on estimated reservoir temperatures, but population concentrations throughout the region are extremely low. The only sizable communities are Bend and Burns. Further resource assessment is needed to determine the direct use geothermal potential for the two towns, as well as for resources sufficient to produce electricity throughout the region.

The U.S. Geological Survey has classified two portions of the region as KGRAs: Newberry Crater and Burns Butte. Burns Butte is a 640-acre area designated as a KGRA because of overlapping lease applications. No competitive leases have been jssued for ej ther area, but there has been active leasing of noncompetitive federal lands and private property in the region. 
Western Snake River Plain

The Western Snake River Plain in east central Oregon is part of a large trough extending from wyoming across Idaho and into oregon. The topography is similar to the Basin and Range region except that the plateaus are generally older and more dissected, and contain more sedimentary rocks. Hot springs and wells are common throughout the area.

The U.S. Geological Survey has designated a large area around the town of Vale as a KGRA. A significant amount of both competitive and noncompetitive leasing and exploration activities have taken place.

Results of geologic and geophysical investigations indicate that the vale KGRA and surrounding area is one of the best geothermal prospects in Oregon. Estimates of reservoir temperatures are in the moderate-to-high range, and reservoir volumes and heat content are expected to be very large.

This excellent resource potential is well matched with existing population centers. These towns are surrounded by rich agricultural land which is the base of the area's economy. Food processing, a major local industry, is readily adaptable to the use of moderate-temperature geothermal energy.

Geothermal resources have been used to a very limited degree in the area for many years, and several new exploration and development programs are underway. Given the excellent resource capabilities and the existing energy demand, the potential for near-term commercialization of the area's geothermal resource is high, particularly for direct applications for food processing, alcohol production and district heating systems. The possibility of thermal fluids of adequate temperature for generation of electricity is not yet known.

Northeastern Oregon

The geologic setting and numerous thermal springs and wells in northeastern Oregon provide favorable indications of geothermal resource potential. Investigations have shown that the area is one of the most promising in Oregon for low-temperature direct geothermal use. The temperature and quality of thermal fluids are well suited for applications in local agricultural activities.

There are no KGRAs in the region, but the area is widely recognized as having significant low temperature resource potential, particularly the La Grande area. Hot springs have been tapped for space heating a hotel near La Grande for decades. Near this site, an alcohol fuel facility is using thermal water to help meet process energy requirements. Expanded use of the local resource in the La Grande area should be realized in the near future. In other areas in northeastern Oregon, warm water wells can be used with heat recovery systems for space conditioning and other direct applications. 
Blank

$-10-$ 


\section{CHAPTER II}

\section{EXPLORATION}

At the present time, geothermal exploration is generally focused on areas displaying surface expressions of a geothermal resource, such as geysers, and/or thermal springs (Figure 2). This attention upon surface expression is similar to the course taken by the petroleum industry during the period of initial development at the turn of the century. However, many technologies developed by the petroleum industry now benefit geothermal exploration. These technologies include geophysical, geochemical, or geologic techniques used to determine the location, depth, size, and heat content of a geothermal field.

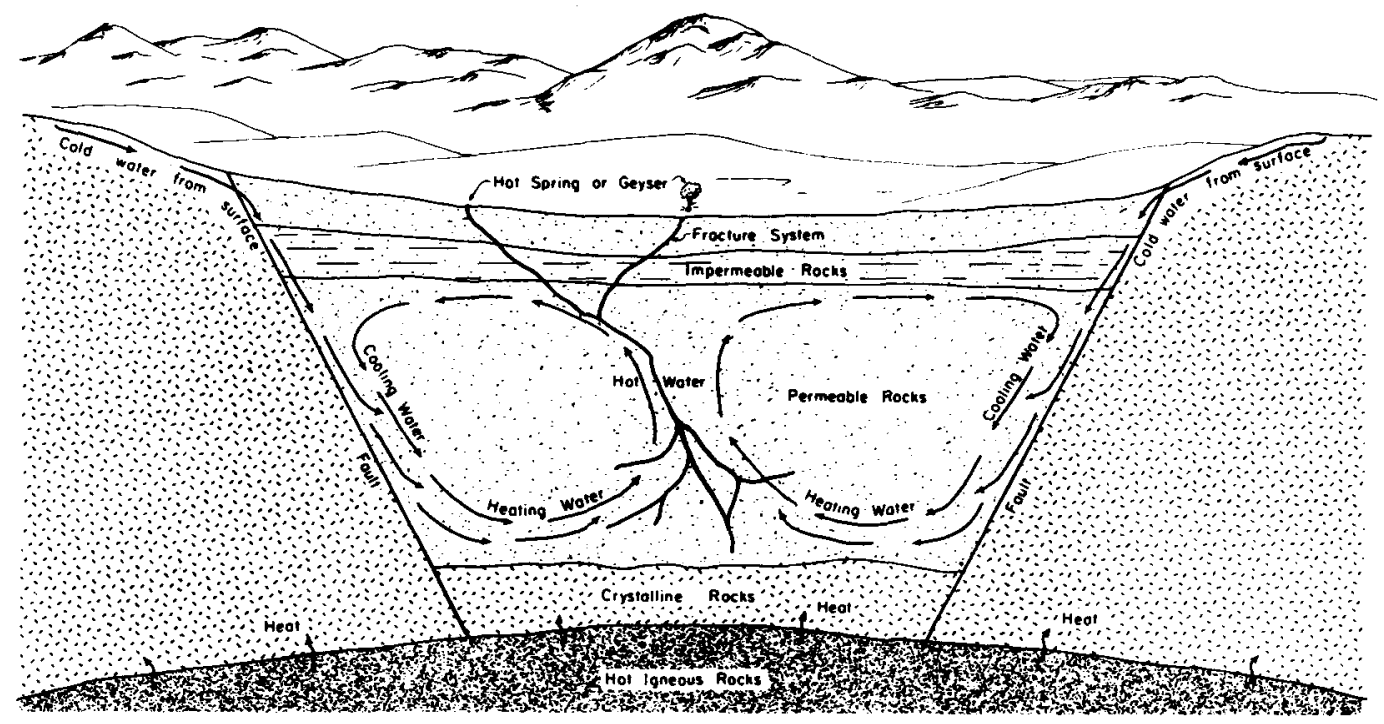

Cross Section of a Geothermal System

Figure 2

The first step for the potential geothermal developer should be a literature search to determine what is already known about a particular area of interest. The research can be divided into two categories: land status and technical information. An evaluation of land status can be made from maps available at the regional office of the Bureau of Land Management (BLM). These maps show land ownership divided into federal (national forest, Indian reservation, military reservation, recreation, and BLM), state, and private lands. More detailed information concerning leasing procedures, permits required, environmental requlations and information on leased lands or lease applications can generally be obtained by contacting the federal land management agency, the state land office, or the state energy office.

Technical information includes both specific geothermal data and general geologic information that may bear indirectly on the nature and occurrence 
of geothermal resources. Specific geothermal information such as locations of thermal springs and warm we11s, has been published by the U.S. Geological Survey in two circulars, 726 and 790 (White and Williams, 1975; Muffler, 1979). A nationwide geothermal gradient map has been published by the American Association of Petroleum Geologists (AAPGUSGS, 1976, a,b) and several researchers have published national heat flow maps (for example; Sass, and others, 1976). In addition, the National Oceanographic and Atmospheric Administration has published a geothermal resource map of the Western United States (See Muliler, 1979, Map No. 1). A bibliography of geothermal publications, Geothr rmal Energy Update, is published by the U.S. Department of Energy (DOE), and is updated quarterly. Detailed state geothermal resource maps have either been published or are in preparation and will be available from the state geology offices. The state geology office is a prime source for reports on the geology and geothermal resources of specific areas, and will have information on earthquake studies, geologic structure, volcanology, distribution of rock units, and hydrology.

The types of geologic information most useful in the early stages of geothermal exploration are: The location and distribution of young volcanic rocks, thermal and mineral springs, warm water wells, recent faults, and chemical analyses of thermal and non-thermal waters.

Proximity of the resource to areas of probable use, and the possible conflict with present land uses must be taken into account along with consideration of land ownership and availability of lands for geothermal leasing.

After a thorough literature review has been completed and land status established, a decision should be made as to whether or not a given prospect area shows sufficient potential to warrant spring sampling and geologic reconnaissance mapping. Leasing and intensive site specific exploration would follow. The various geologic, geochemical, and geophysical techniques available for geothermal exploration are designed to produce specific information pertaining to the nature of the resource. Because each geothermal prospect is unique, there is no one method or series of methods which will work in all circumstances. The costs of various methods must be considered in terms of the benefits received and the value of the particular resource. Verification of a geothermal resource can only be accomplished by drilling a well. The following sections briefly describe those methods which can lead to the siting of a deep exploration well.

\section{GEOLOGICAL METHODS}

Geologic studies determine the age, size, and nature of hydrothermal systems and the nature of structural features controlling the location of a potential geothermal reservoir. Geologic techniques include library research, site evaluation, interpretation of well logs, and area geological reconnaissance. A preliminary geologic evaluation can be 
made from information available from the state geology office and the U.S. Geological Survey (USGS) in the form of published maps, reports, unpublished theses, and open-file reports. A geologic map along with aerial photos (also available from the state or USGS) will indicate areas that should be field checked. A study of existing well logs in surrounding areas will give information concerning subsurface structure and rock types. These geologic studies provide a framework for the interpretation of data from the other exploration techniques.

In the field, a general geological reconnaissance indicates areas of volcanic activity, folding, and faulting which may be associated with the geothermal resources. Geologic mapping of the area will determine the structure and potential for finding a suitable porous rock to serve as an aquifer.

Temperature surveys often give valuable information pertaining to the depth of hydrothermal systems and the reservoir's potential temperature.

Two types of temperature surveys have been popular: The 1-meter ground temperature survey and the intermediate-depth survey. The 1-meter survey is rapid and inexpensive if surface conditions permit the construction of survey holes by simple driving techniques. Holes are normally driven to a depth of 1 to 2 meters (3.2-6.4 feet), and the temperatures are measured with a thermistor probe or a bimetallic thermometer. Ground temperature surveys are conducted only in areas where the hydrologic framework is fairly well known. Large, active flows of shallow ground water can completely mask heat flow anomalies from even the largest and most active geothermal sources. To be most effective, ground temperature surveys require near-surface conditions of low permeability with no large flows of fresh water occurring at depth. Also shallow temperatures can be influenced by seasonal and diurnal temperature changes, vegetative cover, and weather. In these cases, differential measurements may be more accurate. In a differential analysis, the temperatures in the anomalous area are compared to similar measurements made at periodic intervals during the survey, and may also be compared to a reference borehole in an area of displayed activity.

Intermediate-depth surveys are made in holes drilled to depths of 50 meters (160 feet) or more. Temperature and gradient measurements, coupled with resistivity data and heat flow calculations may provide all the information necessary for siting deeper exploratory drill holes.

Figure 3 on the following page indicates increased temperature with depth for selected geothermal gradients. 


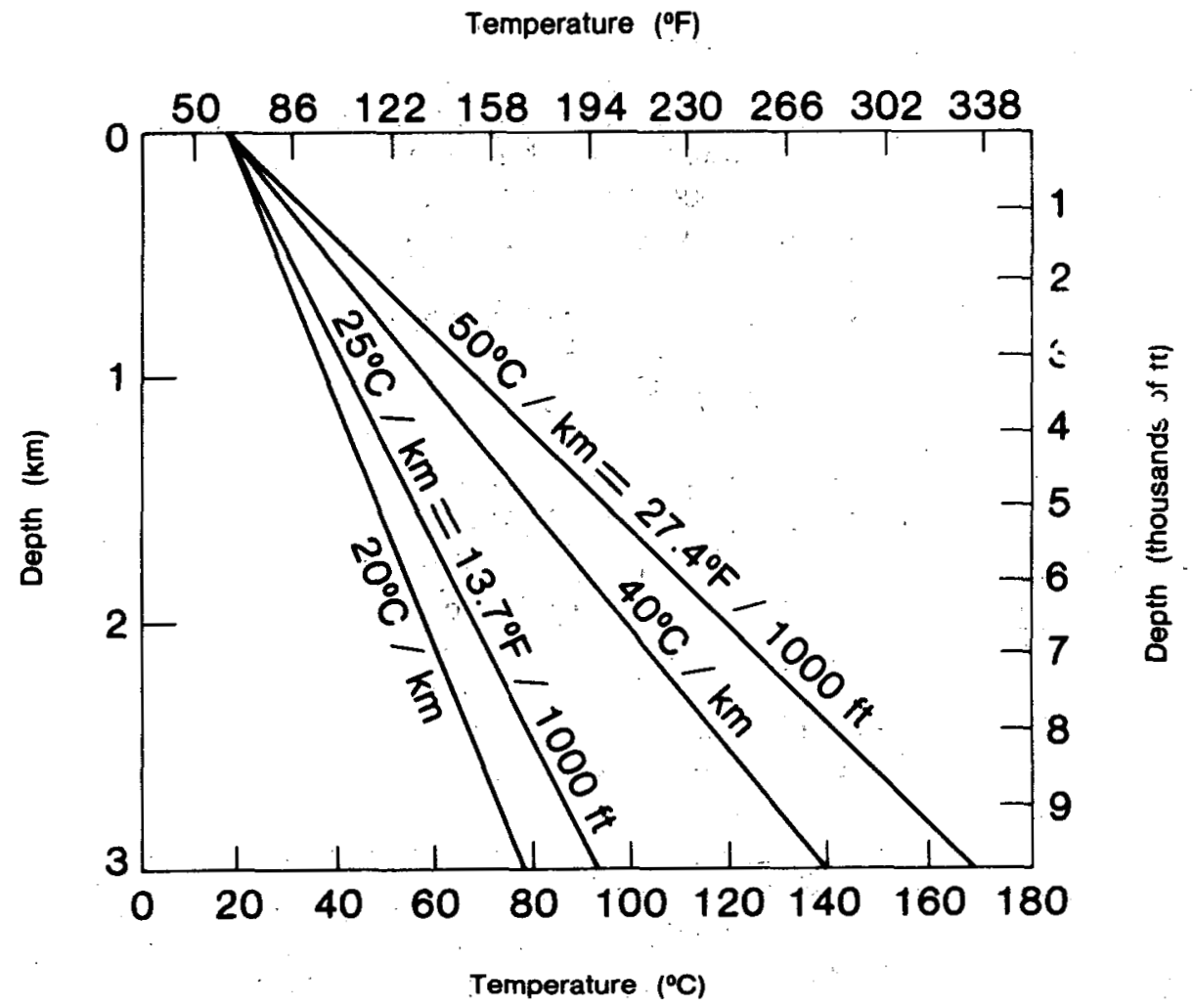

Temperature versus depth for Various Gradients, Ground Temperature Assumed to be $17^{\circ} \mathrm{C}$

Source: Geothermal Handbook, C.S. Leffel, Jr. and R.A. Eisenberg, 1977

Figure 3

\section{GEOCHEMICAL METHODS}

Geochemical investigations involve the sampling of spring systems and the determination of chemical concentrations. Reservoir temperatures calculated from the ionic concentrations of sodium, potassium, calcium, and silica are a valuable indication of actual reservoir temperature. The use of geothermometers, however, requires the making of several assumptions and is thus subject to many uncertainties.

For purposes of geothermometry, it is assumed that certain chemical reactions take place involving the water and the reservoir rock within which the water is held or through which the water passes. The rate of reaction is temperature dependent and, therefore, ionic concentrations in the solute, assumming equilibrium conditions, should be a reflection of temperature. However, the exact reactions which take place are unknown due to several factors. Of these factors, original chemical composition of the water, chemical makeup of the reservoir rock, and length of residence of the water in the reservoir are unknown. Also unknown is the rate at which additional reactions take place as the water rises toward the surface and the degree of mixing that occurs between the hydrothermal fluids and water encountered nearer the surface. Due to the number of unknowns, the accuracy of geochemically estimated 
reservoir temperatures is difficult to assess. Reasonable agreement among the various geothermometers would tend to increase the chance that the estimate is reliable.

Despite the shortcomings of geothermometry and the danger of giving too much credence to any one analysis, geothermometry can and does provide useful information about reservoir temperatures. This is especially true when regional patterns are considered or where spring systems allow for large numbers of related springs to be analyzed.

\section{GEOPHYSICAL METHODS}

A geophysical survey measures variations in the physical properties of the subsurface rocks. These properties include thermal conductivity, electrical resistivity, propagation velocity of elastic waves, density, and magnetic susceptibility. The most distinctive physical properties commonily associated with geothermal systems are high heat flow, low electrical resistivity, and attenuation of high-frequency elastic waves.

The degree of accuracy with which geothermal systems can be detected by geophysical techniques depends on the contrast in the physical properties between the rocks of the geothermal system and the surrounding subsurface.

Geophysical techniques or surveys useful in geothermal exploration can be grouped into three separate categories: Structural methods, electrical and electromagnetic methods, and passive seismic methods.

\section{A. Structural Methods}

Structural methods include active seismic methods (reflection and refraction), gravity surveys, and magnetic surveys. These methods help to refine a regional or local geologic subsurface model.

Active seismic methods involve the use of man-made explosives or surface vibrations to generate elastic waves. The reflection or refraction of these elastic waves off interfaces between rocks of different physical properties can be transmitted to the surface, and the configuration and depth to and/or faults can be calculated.

Gravity surveys, which determine density contrasts of subsurface rocks, have been used both to outline major structural features and to delineate local positive and negative anomalies that may be related to geothermal systems. However, because these anomalies can be produced by factors other than active geothermal systems, gravity surveys are open to gross misinterpretation unless used in conjunction with other exploration techniques.

Magnetic surveys indicate differences in magnetic susceptibility of subsurface rocks, but these surveys are among the least useful in defining a geothermal drilling target. 


\section{B. Electrical and Electromagnetic Methods}

Electrical ànd electromagnetic methods in geothermal exploration measure the electrical resistivity of rocks at depth. Temperature, porosity, salinity of fluids, and/or content of clays and zeolites tend to be higher within geothermal reservoirs than in the surrounding subsurface. Consequently; the electrical resistivity in geothermal reservoirs is relatively low compared to the host rocks. Therefore thicie methods could be used, with other data, to delineate a geothermal sys:em.

Many different electrical and electromagnetic methods are used to measure electrical resistivity at depth. The telluric, audiofrequency magnetotelluric (AMT), and magnetotelluric. (MT) techniques depend on measuring variations in the natural electrical and magnetic fields of the earth. Other electrical techniques utilize man-made current which enters the subsurface by way of two electrodes with the resultant potential measured at two other electrodes. Electromagnetic methods involve the generation of a magnetic field that varies with time, and the detection of either the electrical or magnetic field arising from currents induced in the earth.

An electrical prospecting technique that has been increasingly used in geothermal exploration is the dipole-dipole array. Although the method is logistically simple and is essentially insensitive to rugged topography, effective dipole-dipole investigations require complicated data analysis and are subject to ambiguous interpretation.

The difficulty with interpretation stems from the fact that resistivity is a complicated function of temperature, porosity, salinity, and content of clays and zeolites: For instance; a low temperature, highly saline ground water can provide the same low resistivity anomaly as a high temperature, moderate salinity geothermal system. Therefore, to be. most effective, this method should be used in conjunction with direct temperature, geothermal gradient measurements, or other types of data.

\section{Passive Seismic Methods}

Passive seismic methods include the study of microearthquakes which frequently occur in large numbers in known geothermal regions. One mechanism which can generate microearthquakes is excessive fluid pressure resulting from "hot spots". This pressure reduces the effective stress levels and triggers fault slippage. Thus the presence of microearthquakes may be an indicator of a geothermal anomaly at depth. However, not all geothermal areas exhibit microearthquake activity.

Naturally occurring ground noise may also be an indication of a geothermal anomaly. Special attention has been given to the investigation of ground noise as a possible prospecting tool.

Other geophysical techniques include the following: 1) Micro-wave techniques; 2) radio frequency interference; 3) aero-magnetics; 4) aerial scanning of infrared radiation. 


\section{EXPLORATION COSTS}

The following table shows several exploration methods with approximate times for completion of the surveys and order-of-magnitude costs. It should be stressed that the costs shown are approximate and will vary as a function of many factors including survey detail, accessibility, terrain, and weather. Geothermal gradient and heat flow borehole costs include costs of drilling and completing holes, and well logging. The costs for geochemical procedures include sample collection and chemical analysis. The methods are also characterized as being principally of use in regional and/or detailed evaluations.

TABLE I

Cost of Exploration Activities

\begin{tabular}{|c|c|c|c|}
\hline Method & Time & Expense & Area \\
\hline Consulting geologist & month & $\$ 200-\$ 400$ day & Regional/detailed \\
\hline Airphoto interpretation & month & $\$ 5 / \mathrm{mile} \mathrm{e}^{2}$ & Regional/detailed \\
\hline Water analyses & month & $\$ 100-\$ 200 /$ sample & Regional/detailed \\
\hline Surface geochemistry & month & $\$ 30 /$ sample & Detailed \\
\hline Volatile geochemistry & month & $\$ 20 /$ sample & Detailed \\
\hline $\begin{array}{l}\text { Temperature gradient/ } \\
\text { heat flow boreholes }\end{array}$ & month & $\$ 10-\$ 100 / f t$ & Regional/detailed \\
\hline Electromagnetic methods & month & $\$ 200-\$ 1500 / 1$ ine $\mathrm{mi}$ & Detailed \\
\hline Resistivity & month & $\$ 200-1500 / 1$ ine mi & Detailed \\
\hline $\begin{aligned} \text { Magnetics } & \text { - airborne } \\
& \text { - ground }\end{aligned}$ & $\begin{array}{l}\text { month } \\
\text { month }\end{array}$ & $\begin{array}{l}\$ 25 / 1 \text { ine mi } \\
\$ 200 / 1 \text { ine mi }\end{array}$ & $\begin{array}{l}\text { Regional } \\
\text { Detailed }\end{array}$ \\
\hline $\begin{aligned} \text { Seismic } & - \text { refraction } \\
& - \text { reflection } \\
& - \text { micro- } \\
& \text { earthquakes }\end{aligned}$ & $\begin{array}{l}\text { month } \\
\text { month }\end{array}$ & $\begin{array}{c}\$ 5000 / 1 \text { ine mi } \\
\$ 500-\$ 10,000 / \\
1 \text { ine mi } \\
\$ 1200 / \text { day }\end{array}$ & $\begin{array}{l}\text { Detailed } \\
\text { Detailed } \\
\text { Regional/detailed }\end{array}$ \\
\hline Gravity & month & $\$ 30-\$ 70 /$ station & Regiona 1/detailed \\
\hline Magnetotellurics & month & $\$ 1200-\$ 2000 / 1$ ine mi & \\
\hline Geophysical logging & week & $\begin{array}{c}\$ 2000-\$ 20,000 / \\
\text { hole }\end{array}$ & Detailed \\
\hline
\end{tabular}

Source: Presentation by Jim Combs for Geothermal Resources Council Short Course \#8. 


\section{SELECTED REFERENCES}

Anderson, D.N., and Lund, J.W., eds., 1979, Direct Utilization of Geothermal Energy - A Technical Handbook: Geothermal Resource Council Special Reprot No. 7, Davis, CA.

AAPG-USGS, 1976a, Subsurface Temperature Map of North Americ : U.S. Geological Survey, Arlington, Virginia.

AAPG-USGS, 1976b, Temperature Gradient Map of North America: U.S. Geological Survey, Arlington, Virginia.

Crosby, J.W., 1971, Geothermal Exploration: A Paper Presented at "The First Northwest Conference on Geothermal Power," Olympia, Washington, $19 \mathrm{p}$.

Dobrin, M.B., 1976, Introduction to Geophysical Prospecting: McGrawHill Book Company, N.Y., 3rd Edition, 603 p.

Muffler, L.J.P., ed., 1979, Assessment of Geothermal Resources of the United States--1978: U.S. Geological Survey Circ. 790, 163 p.

Sass, J.H., Diment, W.H., Lachenbruch, A.H. and Others, 1976, A New Heat-Flow Contour Map of the Conterminous United States: U.S. Geological Survey, Open-File Report 76-756, Menlo Park, California, 24 p.

White, D.E., and Williams, D.L., eds., 1975, Assessment of Geothermal Resources of the United States--1975: U.S. Geological Survey Circ. $726,1.55 \mathrm{p}$. 


\section{CHAPTER III}

\section{DRILLING}

A principal objective of the exploration phase is to select drilling sites for geothermal production wells. Both the temperature gradient and heat flow holes drilled at the early stages of exploration and deeper test wells drilled during later stages of exploration are considerably smaller and less expensive than production wells.

The drilling of heat flow or temperature gradient holes and the drilling of slim holes or deeper exploration wells often require very little site preparation and are usually drilled from existing roads. In most instances access to drill sites can be accomplished through the use of logging or fire control roads, this is especially true in national forests.

The equipment required consists of a small rotary drill with a depth capability of from $150 \mathrm{~m}$. (500 ft.) to $600 \mathrm{~m}$. $(2,000 \mathrm{ft}$.$) and which can$ drill a $10 \mathrm{~cm}$. (4 in.) to $20 \mathrm{~cm}$. (8 in.) diameter hole. Drilling is usually accomplished with an air rotary drill whenever possible, but the drill rig should have the capability of drilling with standard rotary bits including coring and tri-cone bits and using a circulating medium such as mud. Additional equipment consists of a compressor for air drilling, a mud tank and pumps for pumping mud and cement.

Temperature gradient holes or wells and deeper slim holes usually require only surface casing to a depth of from $6 \mathrm{~m} .(20 \mathrm{ft}$.$) to 30$ m. (100 ft.).

Since many geothermal wells are drilled in areas where the resource is relatively shallow (less than $600 \mathrm{~m} .(2,000 \mathrm{ft}$.$) ) and temperatures are$ often below $100^{\circ} \mathrm{C}\left(212^{\circ} \mathrm{F}\right)$ the above mentioned equipment may suffice for the drilling of production wells: However, where drilling for deeper and/or higher temperature resources, the site preparation and drilling equipment become increasingly complex.

Independent of the type of drilling which is to be undertaken, the hiring of a competent drilling contractor and a geological consultant to oversee the operation is a must.

The remainder of this chapter is concerned exclusively with requirements and techniques needed for drilling deeper higher temperature exploration and production wells.

\section{DRILLING PREPARATION}

5

Drilling preparation consists of buying or leasing the necessary equipment, hiring personnel and preparing a site. The three main facets of site preparation may involve road construction, drill pad construction, and mud pit and sump construction. 


\section{A. Road Construction}

In comparison to the temporary roads required for some of the earlier phases of exploration, roads at the drilling stage of development must be designed to carry heavier loads and withstand a more constant traffic burden. Steps to achieve this include surfacing the road with rock, gravel or volcanic cinders or mixing oil with the first $0 \mathrm{~cm}$. $(4$ in.) of dirt. In hilly terrain, cut and fill construction muy be required and a means of controlling surface water runoff must be provided. This can be done by constructing drainage culverts parallel to the road bed and providing drainage conduits where the road "fill" crosses drainage.

\section{B. Drill Pad Construction}

A drill pad is an area which is leveled and cleared of vegetation. The pad must be large enough to accommodate the drilling rig and accessories, temporary structures, and crew parking. Some maneuvering room must be allowed for service and delivery vehicles.

The required surface area, including the reserve pit, generally ranges from less than one acre up to approximately three acres. In hilly regions, pad construction will probably involve cut and fill techniques. Special care must be taken to insure that unstable geologic conditions do not exist and are not created when these techniques are employed. It is sometimes necessary to surface the pad with rock or gravel where vehicle or foot traffic is heavy.

\section{Drilling Sump Construction}

A waste discharge pit, often called a "sump", is required for the containment of waste fluids and drill cuttings. The volume of the drilling sump depends on the anticipated depth of the hole. The surface area can range accordingly from less than a hundred to several thousand square meters, and the depth from 1 to $3 \mathrm{~m}$. ( 5 to $10 \mathrm{ft}$ ) or more. Since the drilling sump is designed to contain fluids, special precautions such as the use of a fine clay sealant (e.g., bentonite) are required to insure impermeability. In all cases, the bottom and sides of the drilling sump will be lined with an impervious material and firmly compacted. In some instances, the dritling sump may be lined with plastic or sealed with gunite or some similar material. The drilling sump is positioned so that when the drilling rig is brought in, the drilling sump will be conveniently located adjacent to the rig. In a developing field, the same drilling sump may be used for drilling several wells.

\section{Typical Equipment}

The largest piece of equipment used during the drilling of an exploratory or development well is the drilling rig, which may be from $10 \mathrm{~m}$. (33 ft.) to $30 \mathrm{~m}$. (100 ft.) high. The actual drilling assembly is composed of a variety of accessories, as shown in in Figures 4 and $4 a$, may include (1) the mixing tanks or mud pit where new drilling mud is mixed with chemicals 


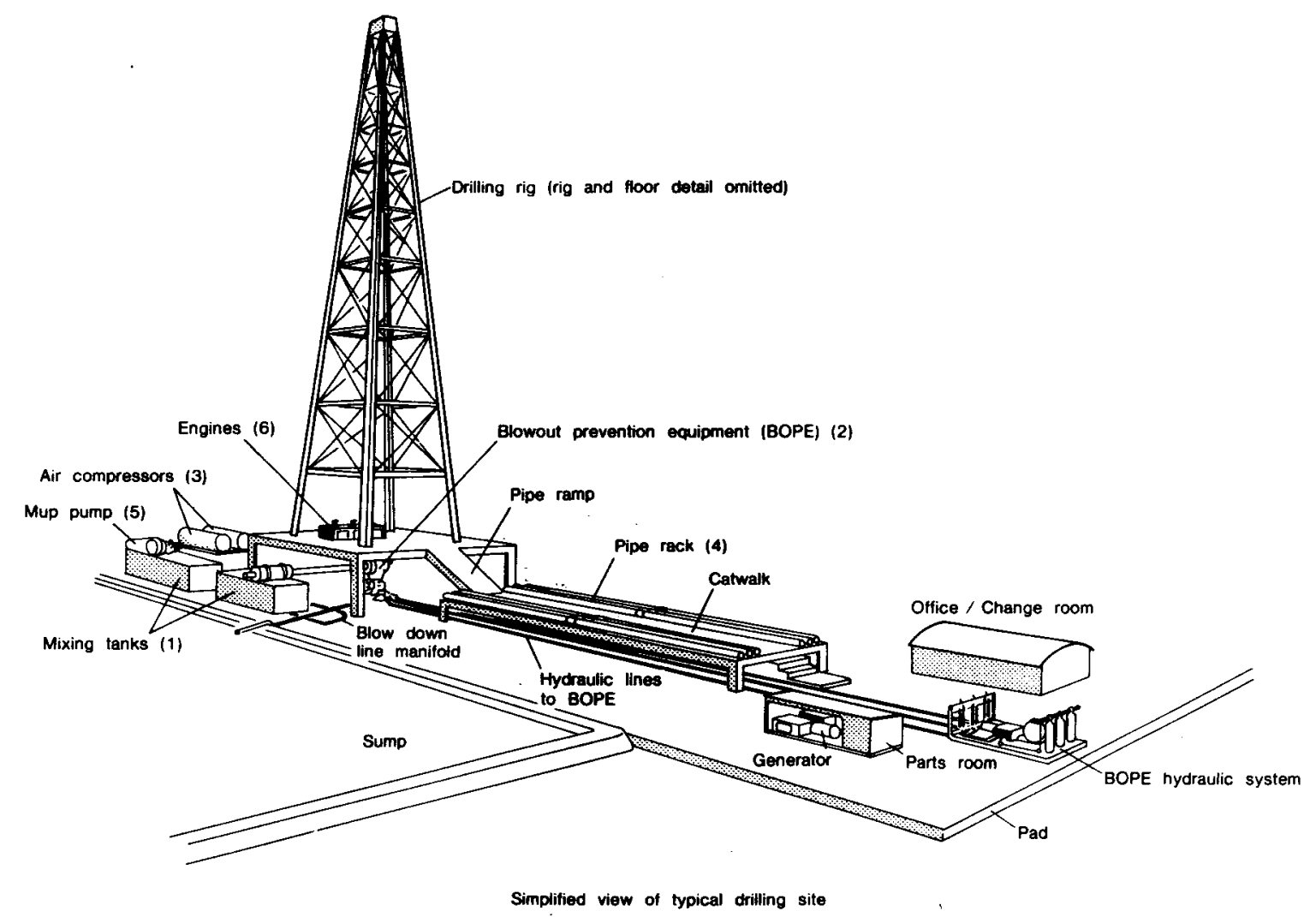

Figure $4 a$

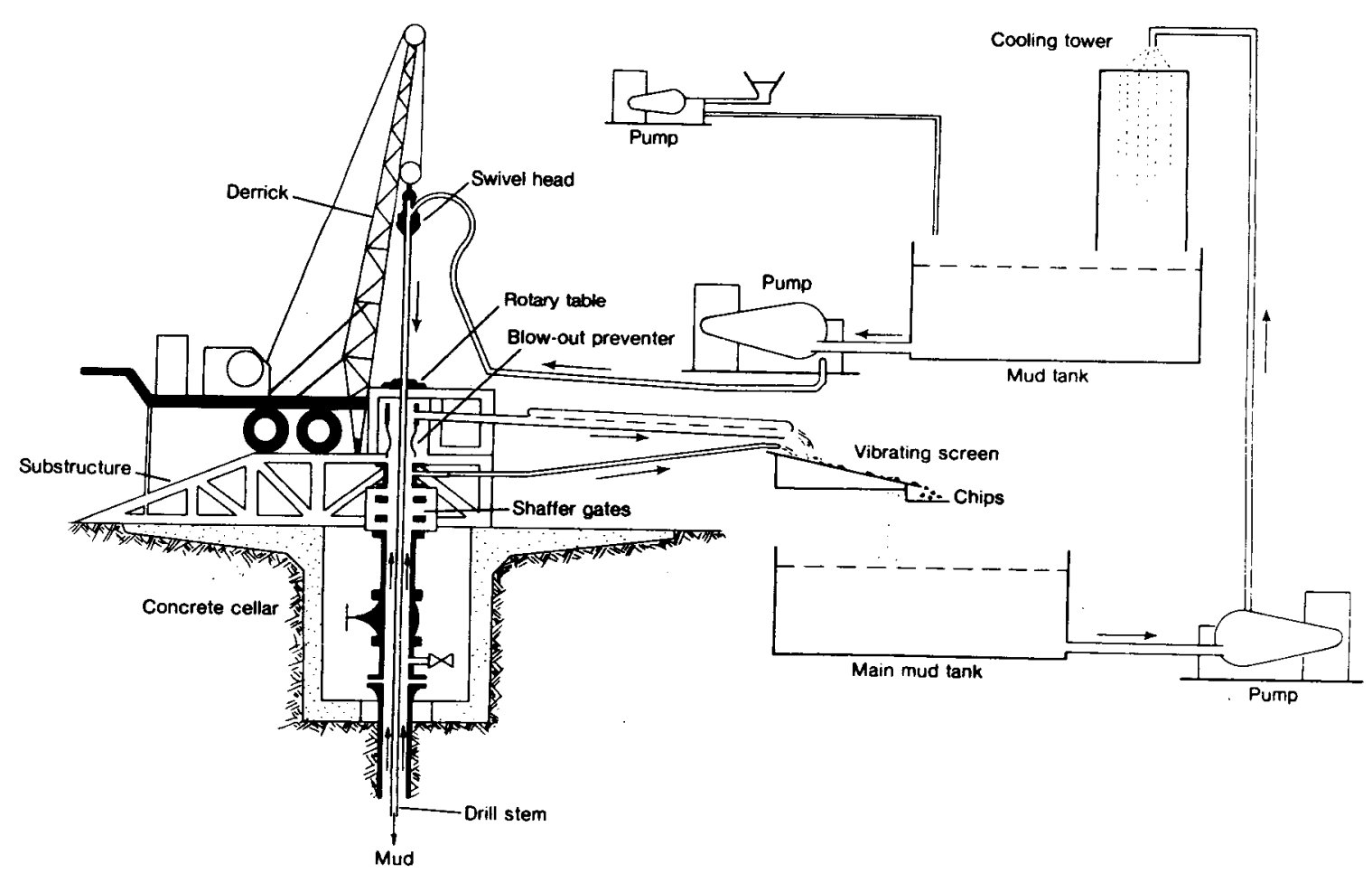

Typical rotary drilling rig and mud circulation arrangements

Figure 4b 
and used drilling mud is stored after being separated from cuttings, blowout prevention equipment, (3) air compressors--for air drilling. (4) the pipe rack--a horizontal rack for storing of pipe in segments, (5) the mud pumps, (6) engines; and (7) the cooling tower used for cooling the drilling mud during the later stages of deep drilling. Not shown are the fuel tanks, water tanks, and a cyclone separator--used in air drilling of deep holes for separating the cuttings "rom the circulating medium.

In addition to the machinery and mechanical accessories required to drill a well, there may be a need for a number of temporary structures for which space must be allowed. Among these are the contractor's and operator's trailers which are used as offices, and the logging geologist's trailer.

\section{E. Personnel}

There are two general categories of workers which keep a drilling rig operating; continuing personnel, whose functions require their full time presence and intermittent personne 1, whose services are required only at certain stages of the drilling operation.

Intermittent personnel include service personnel, who provide such necessary specialized services as cementing, downhole surveys, formation evaluation tests; and the various inspectors, concerned with compliance with local, state, and federal regulations.

\section{DRILLING}

Ground formations in geothermal areas consist mostly of volcanic rocks, characterized by a high hardness index, a high temperature gradient and which are often faulted and fissured. As a result, losses of circulating fluid are frequent and progress may be much slower than when drilling. for $0 i 1$ or natural gas.

The time required to drill a well ranges from a few days to 60 days, depending on the'depth and diameter of the hole, rock type, drilling method, mechanical problems, weather, supply shortages, etc. Since costs are most directly related to drilling time, decisions as to diameter and drilling methods are crucial to an economically. successful drilling operation.

\section{A. Bore Diameter}

It is important that the diameter of a bore be neither too small nor too large. Too small a bore will restrict fluid production by offering a high resistance to its upward flow. On the other hand, too large a bore will require extra time and money to drill. . Theoretically there is an optimum bore diameter which is a function of the flow resistance within the bore itself, the flow resistance within the permeable formation from which the bore is fed with fluid, the cost of the bore, the probable success ratio in winning productive wells and the value attached to the geothermal fluid. In practice, this optimum diameter more or less 
defies calculation: It must be chosen in the light of the results from the first few production bores. At first it is advisable to drill bores of rather moderate diameter (e.g., six inches for hot fluid production) and to increase the size if and when the results appear to justify doing so. Although the best choice of bore diameter must to some extent depend upon the "quality" of the fluid.

\section{B. Rig Types}

There are four basic types of geothermal wells: Slim hole/exploratory wells, used mainly for initial geological information in previously unexplored areas, observation wells used only for monitoring the impacts of previously drilled production wells on the geothermal system, injection wells, used to dispose of geothermal waters and maintain pressures in a geothermal reservoir, and production wells, from which geothermal energy is actually extracted.

Each type of well has its own primary objectives, which logically determine the most desirable drilling techniques. For example, exploratory drilling, in constrast to development drilling, should aim for maximum data recovery, essential for evaluation.

Cable tool and rotary drilling are currently the most common methods. Cable tool drilling provides the best bottomhole temperatures, obtained as drilling progresses. Rotary drilling usually involves larger rigs, greater expense, and relatively rapid progress but may yield less reliable temperature data. On the other hand, where preliminary evaluation of a geothermal area is favorable, deep large-diameter holes often demand large rotary drill rigs for production wells.

1. Cable Tool Drilling

Cable tooling uses a series of components; sockets, jars, drill stems which weigh from 1,500 to 2,500 pounds attached to a drill bit which drives this combination, called a "drill string" down into the earth. Cuttings and debris are removed by means of a bailer, a chamber with a dart and pop door which traps the cuttings and is then pulled to the surface.

Most cable tool rigs cannot drill deeper than 1,500 feet. However, some can penetrate to depths of up to 6,000 feet. The major problem of cable drilling is the limited capacity of different types of equipment to hoist the weight of the drill string and cable.

Cable tool rigs, however, are often available for drilling water wells and are completely satisfactory where high temperatures (above $100^{\circ} \mathrm{C}\left(212^{\circ} \mathrm{F}\right)$ ) are not expected.

\section{Rotary Drilling}

Rotary rigs use a spinning drill stem with a bit attached to the bottom. The drill stem is hollow, so that the drilling medium (mud, air, foam, or water) may pass through it. As drilling proceeds, it is not uncommon to switch media in response to temperature and pressure changes in the hole. 
Most rotary rigs are diesel powered. Power is required to turn the drill stem, to run the compressors, and pulley arrangements for lowering and raising the stem in the hole, and to pump the drilling mediums into the hole and back out into cooling, settling, and storage ponds.

\section{a. Drilling With Mud}

The drilling mud is pumped down through the dritl pine, exits through "jets" in the drill bit and travels back up the anmular space between the drill pipe and the hole, carrying the cuttings up with it. The mud has several important functions. It cools and lubricates the bit, helps break up the rock, its weight helps keep formation pressures under control, and it brings the cuttings to the surface with a minimum of mixing or settling. This latter function enables the logging geologist to correlate the cuttings with depth, and thus determine the type of rock being cut. The mud also forms a wall cake on the inside of the hole and helps prevent the hole from sloughing in. If high temperatures are-encountered, $200^{\circ} \mathrm{C}\left(424^{\circ} \mathrm{F}\right)$, drilling mud can "bake", becoming useless. By changing over to air drilling, this problem can be circumvented. High bottomhole temperature gellation of muds has been avoided by employing special mud systems, such as sepio lite mud, which withstands higher temperatures than conventional muds.

With the drill bit turning on bottom and the drilling fluid in circulation, the drilling team is said to be "making hole." Shallow formations usually drill rapidly. Generally, surface casing is set and cemented before the harder, deep drilling is begun. Surface casing provides a support for attachment of the blowout preventers and related equipment, and maintains the hole through the shallow unconsolidated formations.

During routine drilling, the crew must add sections of drill pipe, as drilling progresses until the bit is worn out and must be replaced. Drill bit life varies greatly with the type of bit and type of formation being penetrated.

Changing the bit is accomplished in an operation called "making a trip," in which the drill pipe is removed from the hole in "stands" which are stacked in a vertical position on the derick floor. When the drill bit has been changed the trip continues until the bit is on bottom and drilling can be resumed.

b. Drilling With Air

During the drilling, the temperature of the drilling fluid is monitored as it enters and exits the hole. As temperature increases begin to cause the mud breakdown, the driller may switch to air, water, or foam as the circulation medium. 
With air or foam as a circulating medium, the same basic functions are fulfilled as with the mud, with a few exceptions. There is effectively very little weight to the column of air, so it does not control formation pressures. Another difference between air and mud as drilling media is that while mud seals ground water from the hole, desirable in the upper portions, the use of air as a circulating medium avoids sealing off the lower portion of the hole, which would reduce the flow of hydrothermal fluids when encountered. When properly applied, air drilling can result in faster penetration rates, longer bit life, better control through lost circulation zones and efficient completion techniques in low-pressure vapor-dominated geothermal reservoirs.

A common practice is to use mud until nearing the production zone, and to use air drilling when penetrating the production zone, thus avoiding sealing of that zone by the mud.

Drilling with air requires much greater velocities to lift the cuttings than does drilling with viscous mud. Sand particles in the air stream are highly erosive and effectively sandblast the drill pipe assembly and the casing. During air drilling, noise levels, if unchecked, may approach 125 bd; however, muffler systems currently in use are designed to reduce the noise to within federal limits.

Air is an attractive fluid for drilling into competent reservoirs because it will not damage the formations and generally improves rate of penetration. However, air drilling does cause rapid erosion of downhole equipment. At The Geysers, where a special anti-erosion additive is used in the air stream, it is still necessary to junk one foot of drill pipe per seven feet of hole. This naturally requires extra services and supplies. Furthermore, completion problems can arise for those wells which produce wet steam because it can erode casing as the high speed fluid strips water film from the casing surface requiring higher quality casing with flush joints to reduce the problem.

\section{c. Drilling With Water}

Many geothermal well drillers are now drilling primarily with water, using mud only in zones where there is difficulty holding the formation. Drilling with water prevents the plugging of permeable producing zones and fractures and keeps the fluid column light enough so that geothermal water can enter the hole. It is the only recommended drilling method for resources of moderate temperatures and low artesian pressures.

\section{Turbo-Drilling}

With conventional rotary drilling the mechanical power drive is placed at the ground surface and the driving torque is transmitted to the bit through the long drill-stem. In very deep holes this driving torque may cause two or three complete rotations of the 
stem, so that the bit lags behind the drive by several hundred degress of angle, causing damage to the casing and unlined bore walls. Various attempts have therefore been made to fix the driving unit at the base of the hole, close to the bit, so that the stem--though still twisted by the torque--need rotate at a very low rate. The turbo-drill makes for improved penetration rates and easy adaptability to directional drilling. The cost of using the turbo-drill at various depths is comparable to that of conventional drilling.

\section{Directional Drilling}

The directional or deviated hole is a hole drikled at an angle or series of angles to reach a bottom hole location other than directly beneath the rig. It is used when made necessary by unstable surface conditions; access problems, or the presence of an immovable object directly above the desired bottom hole location. The directional hole may also be used to drill to more than one subsurface location from a single surface location (especially common in offshore 0.11 drilling), thus economizing on surface pipework and land acquisition costs. Directional drilling may entail angels of up to $85^{\circ}$ in ideal conditions, such as in poorly compacted sediments with little faulting and simple geologic structures. However, geothermal resources often occur in hard metamorphic or igneous rock in typically faulted, complex structures. Under these conditions, control is extremely difficult to maintain and directional drilling is avoided whenever possibie.

The directional hole costs on the average one and one-half times as much as the straight hole. The added costs are incurred through directional drilling equipment services, difficulties such as maintaining the angle and bearing of the hole, maintaining good return of cuttings, and equipment failure. In view of these special costs and the difficulties. in directional drilling, it is avoided whenever possible.

\section{Blowout Prevention}

When the pressure within a penetrated formation exceeds the pressure exerted by the column of fluid or air in the drill hole, the well may blow out. If this occurs in a geothermal well, the effluents will consist of steam and/or hot water with dissolved salts and possibly noncondensible gases such as hydrogen sulfide, carbon dioxide or ammonia. The primary danger is to operating personnel, who could suffer burns from steam or water and injury from falling objects. In some cases a hazard due to hydrogen sulfide may result.

A secondary impact: would be the unchecked flow of toxic gases or water to the surface, resulting in air and water pollution. The blowout may also create excessive noise. Should a blowout continue unabated, sand, gravel, and rock fragments may erode the surface material from under the drilling.platform, enlarging the hole to form a crater, into which the rig itself may collapse.

Controls must be installed: on the casing to prevent such an occurrence whenever high temperature, high pressure well:s are drilled. Necessary blowout prevention equipment depends upon the area being drilled, depth 
of the well, expected pressures, and past drilling experience in the area: The equipment consists essentially of one or more of the following three items: Annular preventer, a device which may be compressed to close the annular space between casing and drill pipe; pipe ram, a ram with an opening of a size to close around the drill pipe; blind, blank, or complete shut-off ram, a ram which is used on an open hole when there is no drill pipe in the hole.

The blowout prevention equipment and attendant fittings are installed on top of the casing (Figure 5). Proper use of these controls will prevent blowouts and resulting adverse effects on the environment that could be caused.

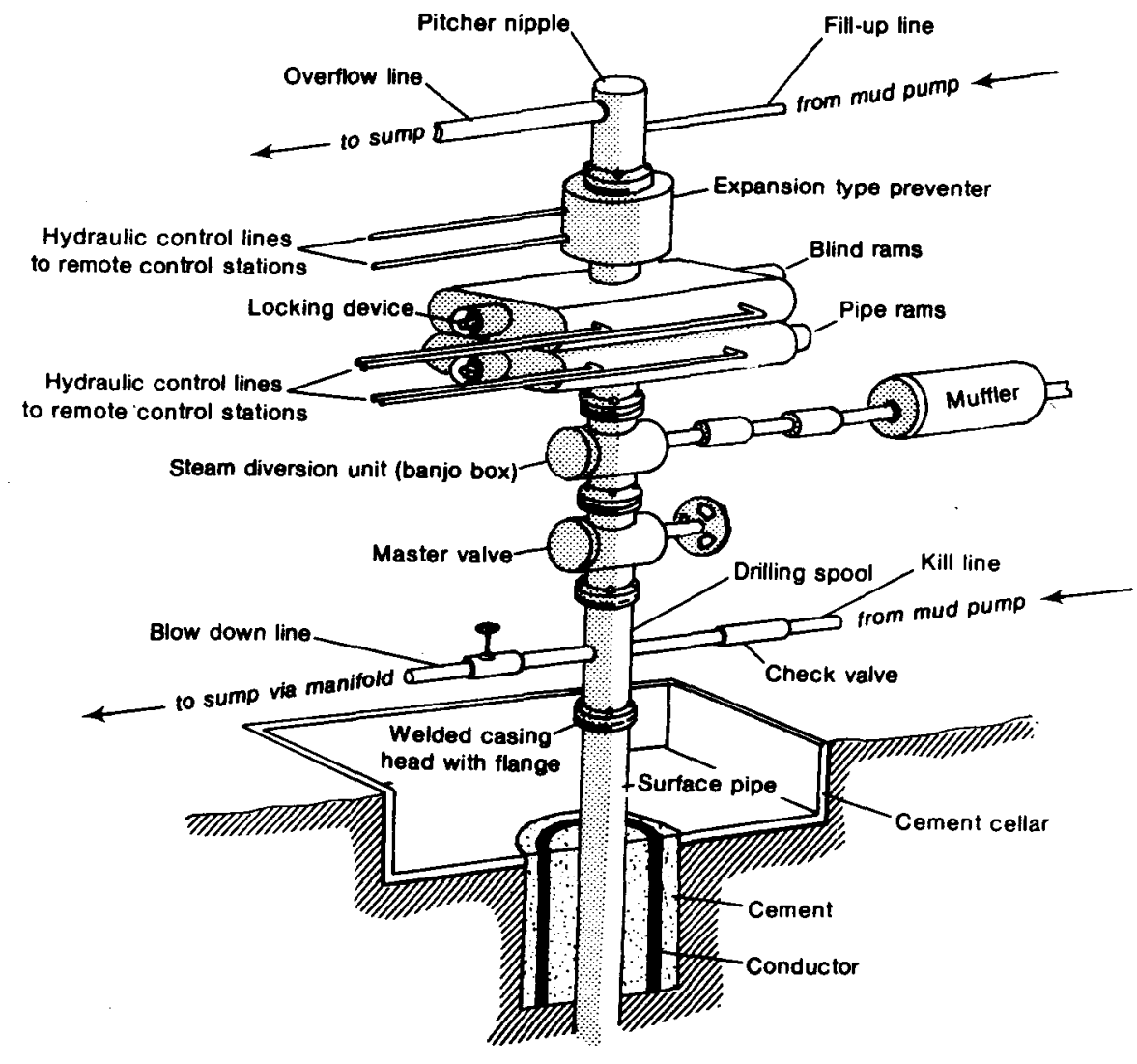

Typical blowout prevention equipment

Figure 5

Usually, the blowout prevention equipment is inspected and pressure tested at least once on each string of casing by personnel of a federal, state, or local regulatory agency. The equipment is inspected daily by operating personnel, and is pressure-tested at least once a week and following all repairs. During drilling operations, the rams, both blind and pipe, are operated once each time the drill pipe is removed from the hole and the expansion type preventer once each week. 


\section{POST-DRILLING}

\section{A. Casing}

"Casing" refers to the lining of the well with concrete, pipe or screening for structural support and sealing. Both production and exploratory wells must be cased during drilling to prevent collapse of the hole and to maintain zone and aquifer separation.

There are five basic types of casing:

Conductor pipe is the first and largest diameter string of casing to be installed, extending from the surface to a minimum of 40 feet. Intermediate string of casing is the casing installed in order to seal out nongeothermal water producing zones, and to prevent caving below the bottom of the conductor pipe or surface casing. Production string is the casing that extends from the production zone to the surface and through which the resource is produced. Surface casing runs between the conductor pipe and the blowout prevention equipment in order to seal out ground water zones. Screen or perforated casing is used in the production zone to prevent caving without sealing the zone.

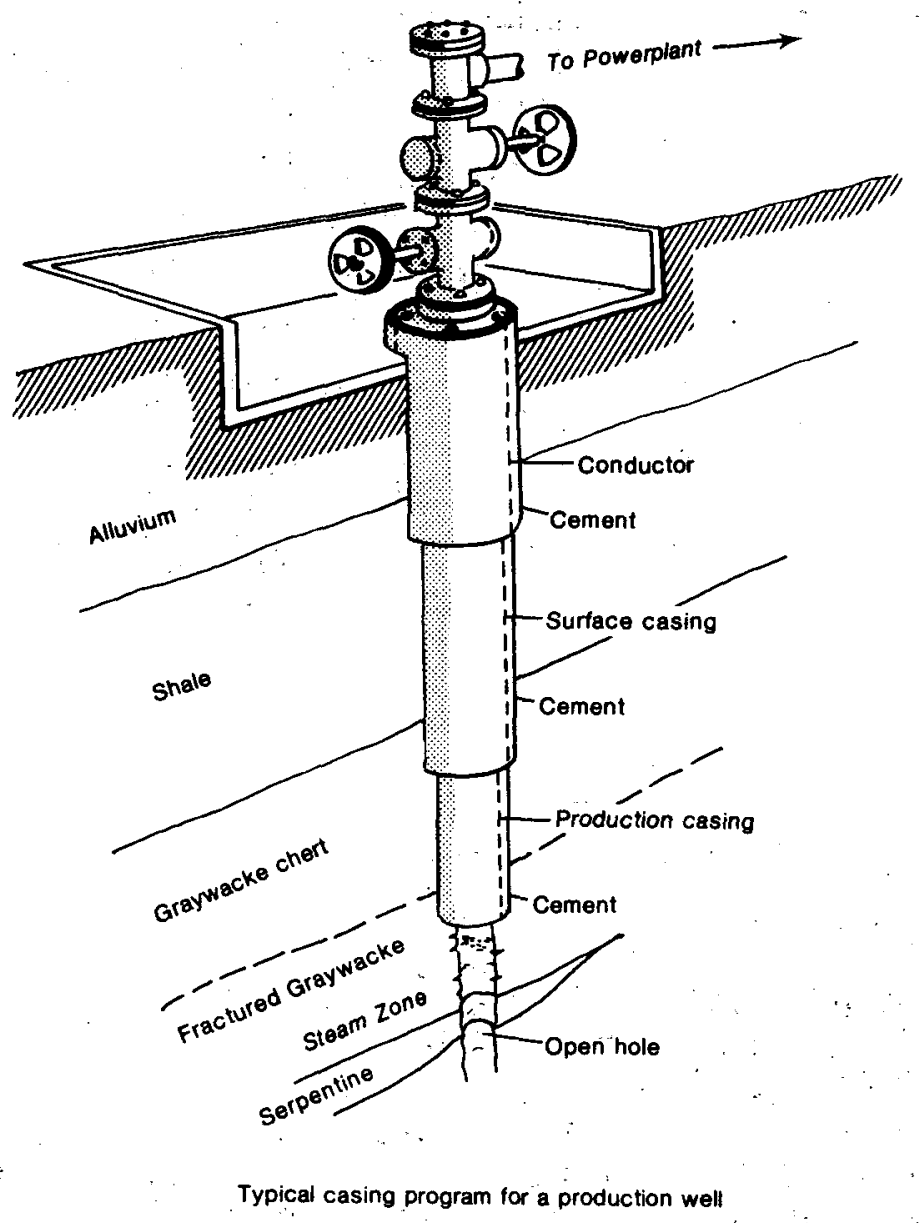

Figuré 6 
The casing program which is selected will depend upon the geology (i.e., hard rock or loosely consolidated sediments) and type of geothermal system. The casing program of an exploratory or production well will generally consist of the following for any area: Conductor set to $15 \mathrm{~m}$. (50 ft.) surface casing to $+60 \mathrm{~m}$. (200 ft.), primarily to provide an anchor for blowout equipment, and a string of production casing. Sometimes an intermediate casing is used between the surface casing and the string of production casing to protect interlying zones. For hard rock areas such as The Geysers in California, the final portion of the well is open hole below the intermediate casing (Figure 6). For areas with loosely consolidated sediments such as Salton Sea in California, slotted liner is required in the lower portion to control sand flow. An effective casing program will prevent significant environmental impact. If done improperly, geothermal fluids may leak from the producing zone to overlying aquifers, or even to the surface.

The corrosion of casing is nearly always caused by hydrogen sulfide and other acids. Formations yielding water of $10 \mathrm{w} \mathrm{pH}$ value, as determined by sampling during the drilling of the well, should be cemented off.

\section{B. Testing The Well}

Upon completion of drilling, the geothermal well is tested for production by pumping the well and by gauging the volumes and temperatures of geothermal fluids. Flow to the surface is usually directed into the drilling sump, which is used as a test sump. Federal regulations do not allow the use of evaporating ponds or existing water bodies. The impact from testing is from noxious gases and toxic elements such as arsenic and boron in the geothermal water. The gases, if occurring in quantity, are removed, and the toxic elements are contained within the sump or in a portable tank. During testing of a steam well venting is done through a system of mufflers so that noise does not rise above ambient levels at a distance of about $.8 \mathrm{~km}$ (one-half mile).

Measurements are made on wellhead pressure, enthalpy, mass flow, rates of change of mass flow, ionic concentrations, total constituents analyses, etc. Geothermal fluid not flashed to steam must be stored on the site or discharged to the surface drainage system. Injection is usually not possible at this time, as two wells are required, along with a more complete knowledge of the resource. In addition to the testing, a well may be pumped or allowed to flow for several days to clean the hole of any material which may interfere with production.

\section{Abandonment}

If a well is not productive, or becomes noncommercial due to corrosion, ebbing production, or other causes, it may be abandoned. Plugging and abandonment of a well must comply with federal, state, and local environmental regulations. Like virtually all of the steps in well drilling, requirements for abandonment vary according to the type of hole drilled, depth, formations encountered, and other factors.

Generally, the simplest abandonment requirements are for shallow (less than $150 \mathrm{~m}$. or $500 \mathrm{ft}$.) temperature gradient holes. These wells are 
filled with drilling mud to a depth of $3 \mathrm{~m} .(10 \mathrm{ft}$.$) and with a cement$ plug from $3 \mathrm{~m}$. (10 f.t.) to the surface or with cement from total depth to surface, depending on the character of fluids encountered.

As a rule, exploratory or production wells are deeper and more complex, requiring correspondingly more plugs. The number of plugs required generally increases with the depth, the complexity of the regional geology, the complexity of the well, the material left in the hole such as twisted-off drill pipe, and other conditions. The int nt is to prevent the movement of fluids in the well bore so that there is no movement between aquifers and no flow to the surface. Portic.is of the well bore not filled with cement are filled with drilling mud. Once all plugs have been set, the casing is cut off at least $2 \mathrm{~m}$. ( $6 \mathrm{ft}$.) below the ground surface and capped by welding on a steel plate. Collars, pads and all other structures are removed and the surface area returned to the original grade. All remaining refuse must be removed from the area and the site reclaimed or revegetated to the specifications of the surface managing agency. 


\section{SELECTED REFERENCES}

Armstead, H.C.H., 1978, Geothermal Energy: Halstead Press, John Wiley and Sons, New York, p. 71-87.

Bammerman, J.K.; Davis, N.; and Wolke, R., 1978, Geothermal Drilling Fluid Systems: in Geothermal Resources Council Transactions, v. 2, p. 27-29.

Idaho Geothermal Handbook: 1979, published by the Idaho Office of Energy, p. 36-42.

Geotherma1, Energy: 1975, Informatics, Inc. November 1975, p. 100-102.

Matsuno, K., 1973, Drilling for Geothermal Steam and Hot Water: in Geothermal Energy, p. 73-83 (Earth Science, 12).

Miller, L.G.; Prestwich S.M.; and Gould, R.W., 1978, Drilling and Directional Drilling a Moderate-Temperature Geothermal Resource: in Geothermal Resources Council, Transcations, v. 2, p. 455-456.

Raschen, R. and Cook, W.S., 1976, Exploration and Development of Geothermal Resources: U.S. Geological Survey, September 1976, p. 8-15.

Geotherma1, Handbook: 1976, U.S. Department of Interior, U.S. Fish and Wildlife Service, p. 144-158.

Vernado, S.G. and Stroller, H.M., 1978, Geothermal Drilling and Completion Technology Development: in Geothermal Resources Council, Transactions, v. 2, p. 675-678. 
Blank 
The utilization of geothermal resources can be divided into two very broad categories: (1) utilization for the production of electricity, and (2) direct utilization in industry, space conditioning, and agriculture and aquaculture (Figure 7). These two broad categories can be further broken down on the basis of temperature and the relative percentage of steam and water.

Utilization of geothermal resources is no different than the use of steam or hot water produced by burning 0i1, coal, wood, or through nuclear reaction. The main differences lie in problems of corrosion or scaling which result from the chemical composition of some geothermal resources, making material selection critical; and the fact that geothermal resources must be used within relatively short transmission distance of the source.

\section{ELECTRICAL GENERATION}

The generation of electricity using geothermal resources began in Larderel10, Italy in 1904. Worldwide generating capacity has been slow to develop and it has been only since the early 1960's that significant gains in total generating capacity have been achieved.

TABLE II

Worldwide Geothermal

Electrical Generating Capacity

$\begin{array}{lcc} & \begin{array}{c}\text { Installed } \\ \text { Capacity }\end{array} & \begin{array}{c}\text { Future } \\ \text { Capacity MW* }\end{array} \\ \text { China, People's Republic of } & 1 & -- \\ \text { El Salvador } & 60 & 35 \\ \text { Iceland } & 62 & -- \\ \text { Italy } & 420.6 & 55 \\ \text { Japan } & 165 & 30 \\ \text { Mexico } & 150 & -- \\ \text { New Zealand } & 202.6 & 710 \\ \text { Philippines } & 59.2 & -- \\ \text { Turkey } & 0.5 & 1019 \\ \text { U.S.S.R. } & 5 & 1849 \\ \text { United States } & 663 & \\ & 1,788.9 & \\ \text { *Planned to be on line by 1982. } & & \\ \text { Courtesy of John W. Lund, Geo-Heat Utilization Center. }\end{array}$




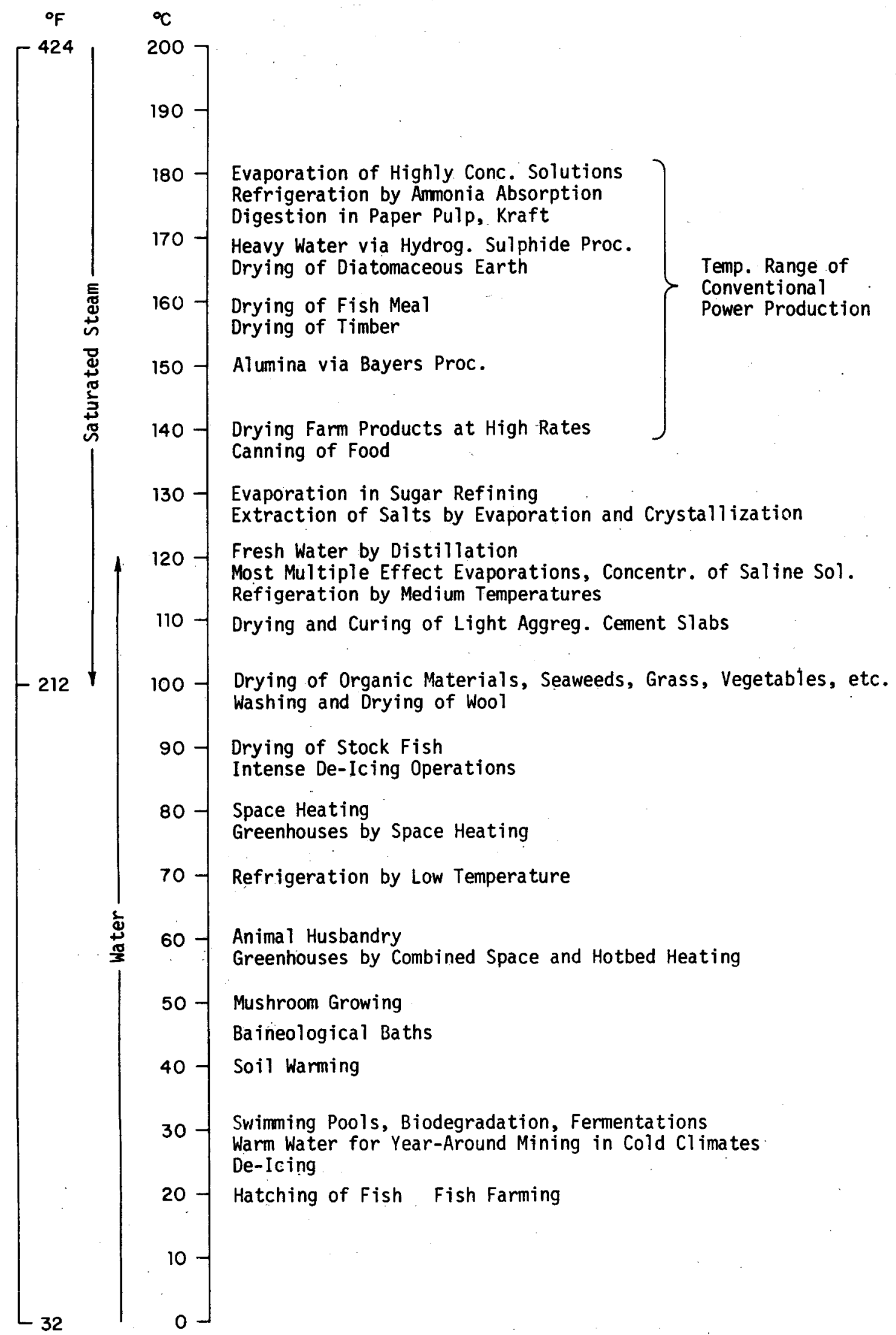

Direct thermal application of geothermal energy.

Figure 7 
Electrical generation can be accomplished utilizing geothermal resources in a number of ways dependent upon the temperature and the relative percentage of steam and water. The four primary generating plant types include: (1) those utilizing dry steam, (2) flashed steam in either single or multiple flash units, (3) binary plants which utilize secondary working fluids where for some reason, the direct use of the geothermal resource is impossible or undesirable, and (4) plants utilizing a combination of flashed steam and binary technology. A fifth plant type is a hybrid where geothermal resources are used in conjunction with fossil fuels, solar energy, or biomass for electrical generation.

\section{A. Dry Steam Plants}

To date, the majority of the worldwide geothermal electrical generation capacity is from dry steam fields, such as those at Larderello, Italy and The Geysers in California.

In a dry steam plant (Figure 8 ) the steam is brought to the surface by a series of wells, and after separating out rock debris, the steam is piped directly through a collector into the steam turbines which in turn drive the generators. On exiting from the turbine, the steam is condensed in a cooling tower and injected back into the reservoir.

\section{Dry Steam Power Plant}

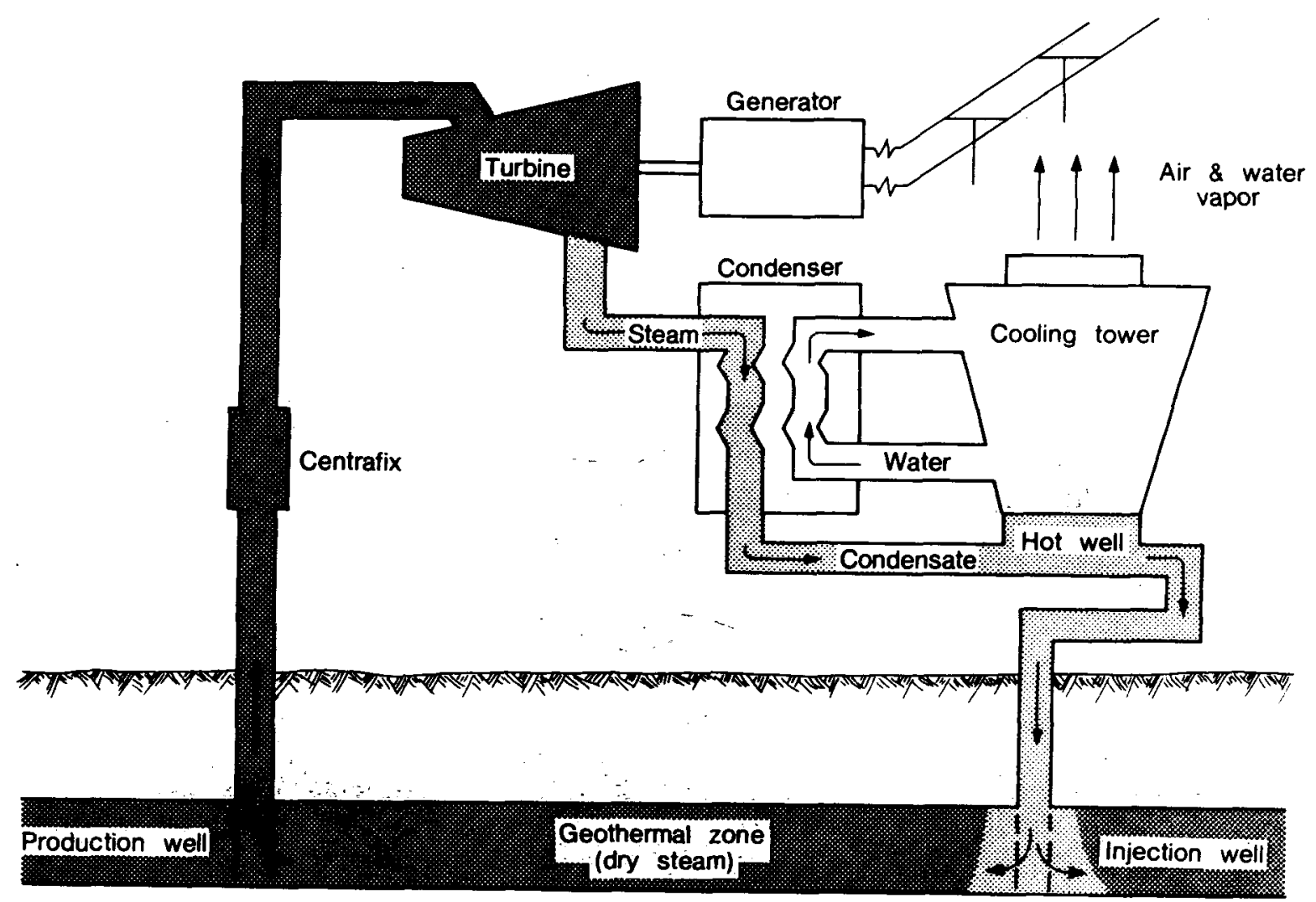

Courtesy of Earth Science Laboratory. University of Utah Research Institute

Figure 8 


\section{B. Flashed Steam Plants}

Flashed steam plants as pictured in Figures 9 and 10 must rely upon that fraction of steam which will flash from the superheated water as the resource is brought to the surface and the pressure is reduced. Plant efficiency can be increased in many cases by flashing at decreasingly lower pressures in order to obtain as much steam as possible from a given volume of water. Once the steam is separated from the water, it is fed into the turbines as in the dry steam plant. The remining water fraction and condensate are both reinjected.

\section{Flash Steam Power Plant}

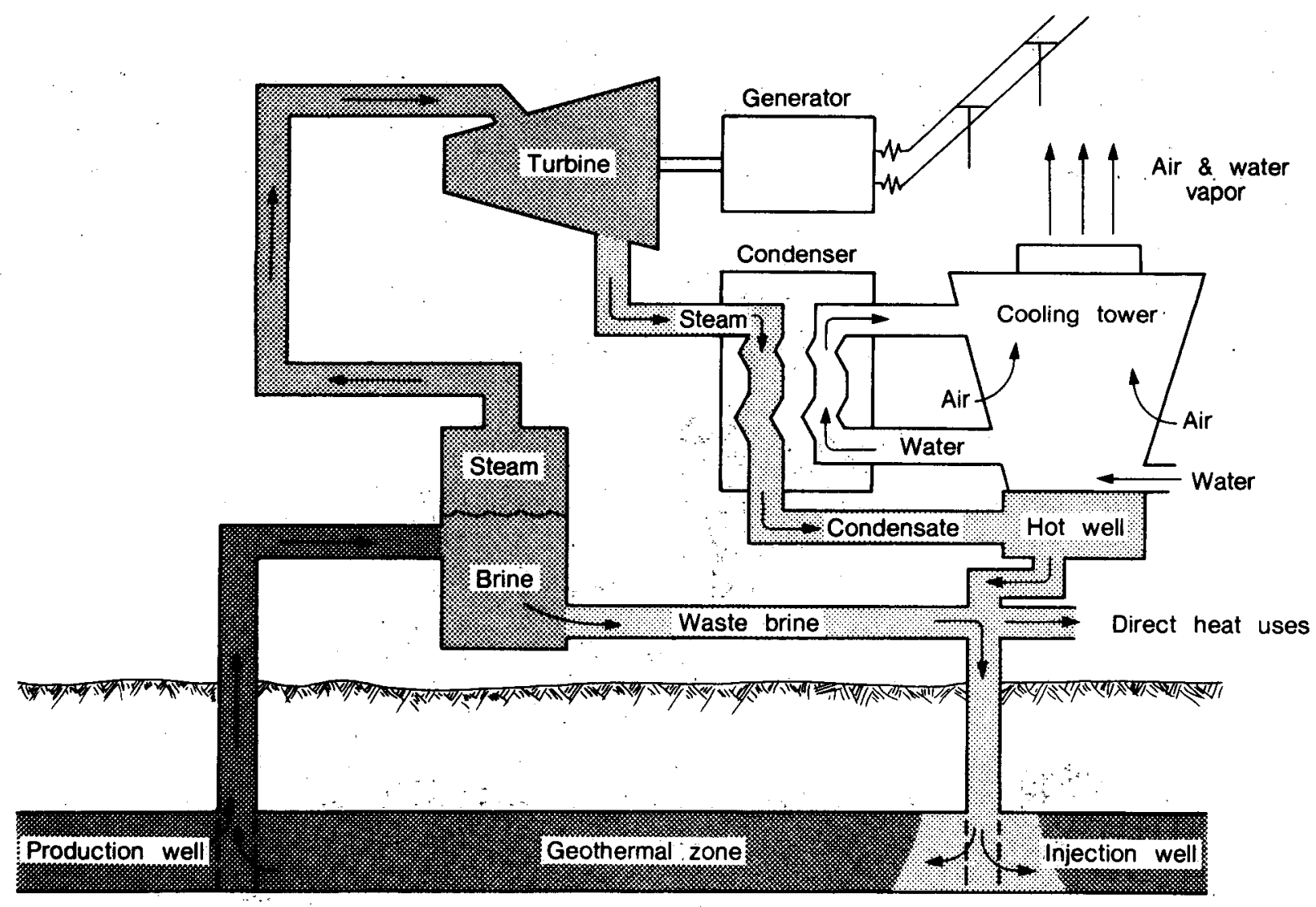

Courtesy of Earth Science Laboratory. University of Utah Research institute

Figure 9 


\section{Double Flash Power Plant}

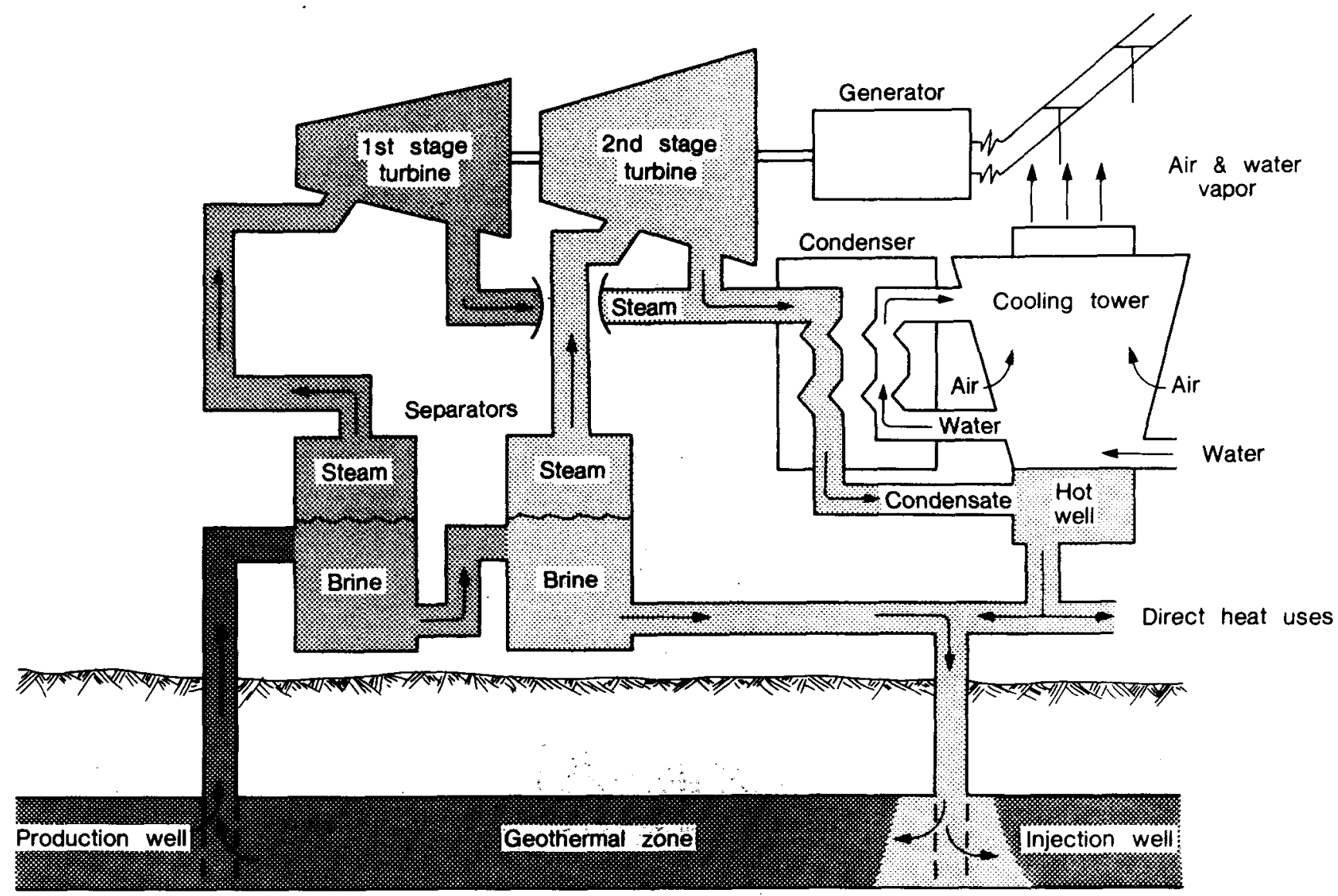

Courtesy of Earth Science Laboratory, University of Utah Research Institute

Figure 10

\section{Binary Plants}

Binary plants (Figure 11) use secondary working fluids such as freon, isobutane, or isopentane to drive turbines.

The use of a binary cycle plant allows for the generation of electricity utilizing geothermal fluids which are below the temperature where flashing will produce substantial amounts of steam or where because of corrosion or scaling problems associated with some geothermal resources, direct use is impractical.

In the binary cycle plants, such as that found at Raft River, Idaho, the geothermal fluid is pumped from the production well through a heat exchanger where the secondary fluid is vaporized, and then geothermal fluids are injected into the reservoir. The vaporized secondary working 
fluid is then piped through the turbines, which drive generators, and finally condensed for reuse. By maintaining the reservoir pressure of the geothermal fluid, gas release is eliminated, thus reducing some scaling or corrosion problems as well as eliminating the potential for major air polution from gases often encountered in geothermal reservoirs. In addition, by using a heat exchange, scaling and corrosion can be limited to the primary mode of the heat exchanger making for greatly increased ease of replacement or repair.

Binary cycle plants can also be used in conjunction with flash d steam plants. In such an arrangement, the water that remains after flashing is passed through a binary cycle unit thus extracting additional energy and making for more efficient use of the resource.

\section{Binary Cycle Power Plant}

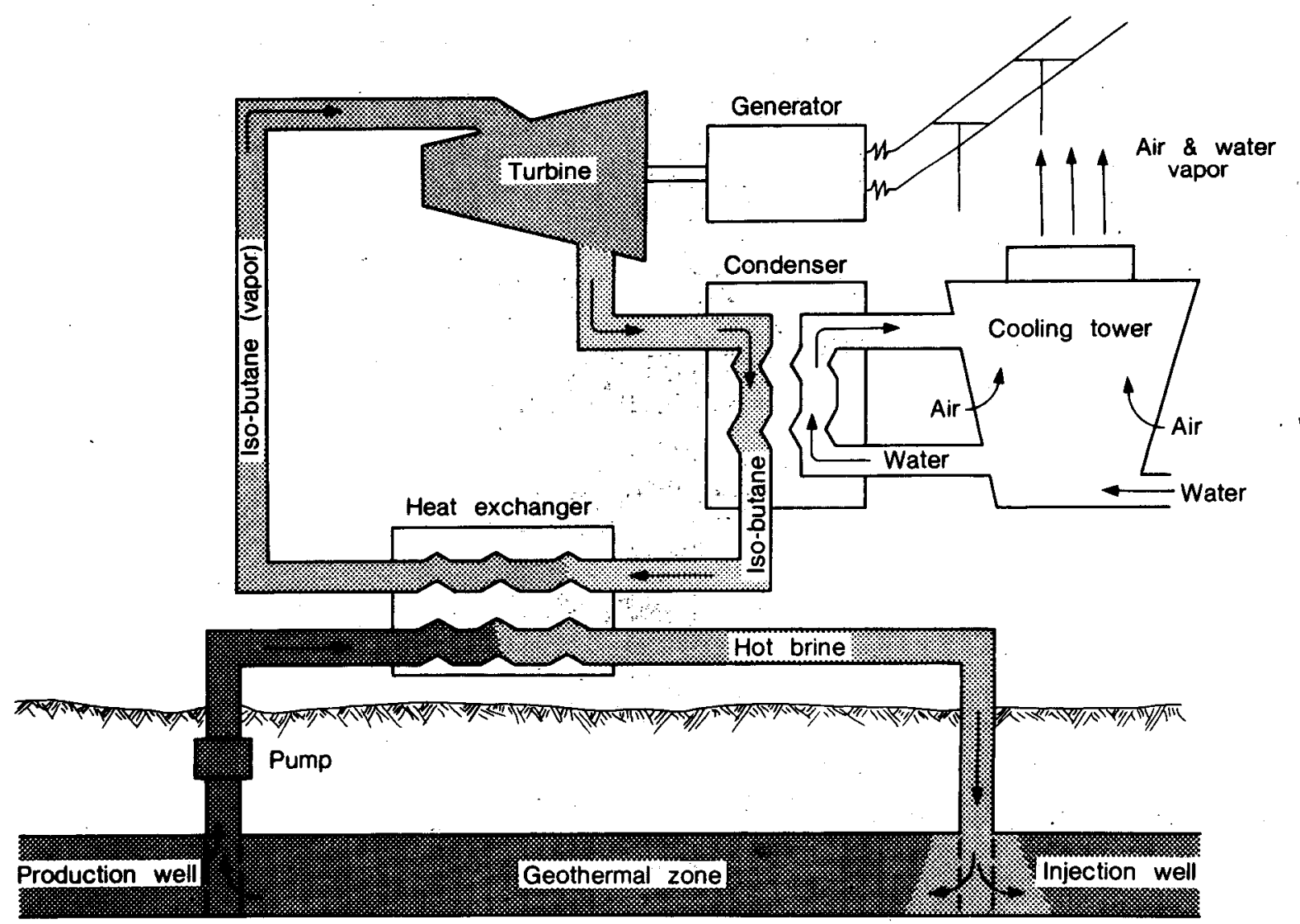

Courtesy of Earth Science Laboratory. University of Utah Research Institute

Figure 11 


\section{Hybrid Plants}

Hybrids make use of geothermal resources together with a secondary energy source such as coal, biomass, or solar energy. The hybrid plant can utilize geothermal resources which are below the temperature where flashing produces usable amounts of steam, and in some cases, below the temperature needed for economical use in binary cycle plants. In a hybrid plant, the geothermal resources are used as preheated water which is boosted through the use of a secondary energy source to produce steam. In some cases, such as with the use of biomass, the geothermal resource is also used for drying the organic material, thus increasing the burning efficiency.

\section{DIRECT UTILIZATION}

Direct use of geothermal resources can supply a large part of our energy needs for industrial processing, commercial and residential heating and cooling, agriculture, and aquaculture. Geothermal resources with temperatures ranging from $10^{\circ} \mathrm{C}\left(50^{\circ} \mathrm{F}\right)$ to $100^{\circ} \mathrm{C}\left(212^{\circ} \mathrm{F}\right)$ can successfulty be utilized (Figure 12) although below $60^{\circ} \mathrm{C}\left(140^{\circ} \mathrm{F}\right)$ the temperature generally must be boosted through the use of conventional boilers or heat recovery systems to meet the needs of industrial processing and space conditioning. The direct use of geothermal resources has several advantages over the use of the resource for electrical production. These are:

1. Resources with direct use potential are believed to outnumber electrical prospects by as much as ten to one.

2. Drilling can generally be accomplished at much lower costs using conventional water well drilling equipment and technology.

3. Development time is usually much shorter than with electrical generation development.

4. The resource can be transported over considerable distance with temperature losses of as little as $0.1^{\circ} \mathrm{C}\left(0.2^{\circ} \mathrm{F}\right)$ per kilometer in comparison to steam transport which is limited to approximately 2 kilometers.

5. A conversion efficiency of from 70 to 90 percent is possible in comparison to a conversion efficiency of from 5 to 25 percent for electrical production.

Although the direct use of geothermal energy has been proven to be the most efficient use of the resource, the efficiency can be enhanced through cascading or multi-stage use of the resource. This is also true of resources which are or may be utilized for electrical generation. An optimized cascading of the resource could include electrical generation, industrial processing, space heating, and finally aquaculture or recreational use. Cascading will also improve the economic picture of any geothermal development and should be considered whenever possible. Details of economic evaluation are presented in Chapter $v$. 


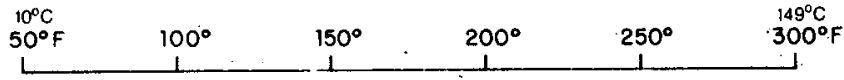

Malt beverages

Distilled liquor

Scalding

Soft drinks

Biogas processes

Gypsum drying

Alumina

Aggregate drying

Cement drying

Rubber vulcanization

Styrene

Autoclaving and cleanup

Pharmaceutical

Acrylic

Kaolin drying

Organic chemicals

Lumber

Textile mill

Rayon/acetate

Coal drying

Pulp and paper

Concrete block curing

Synthetic rubber

Metal parts washing

Leather

Furniture

Beet sugar evaporation Cane sugar evaporation Beet sugar pulp drying

Blanching and cooking

Fruit and vegetable drying

Whey condensing

Milk evaporation

Beet sugar extraction

Carcass wash and cleanup

Pasteurization

Mushroom culture

Food processing

Pickling

Greenhousing

Aquaculture

Soil warming

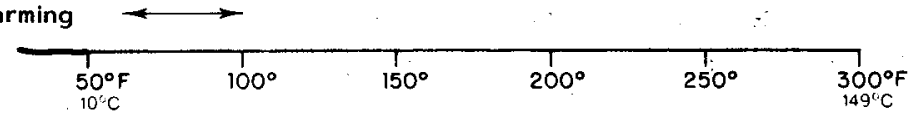

TEMPERATURES REQUIRED FOR VARIOUS DIRECT GEOTHERMAL APPLICATIONS

Figure 12

$-42-$ 


\section{A. Industrial Processing}

The energy needs of many industrial processes can be fully or partially met using geothermal energy (Figure 12).

The earliest industrial application involved the use by the Etruscans of boric acid deposited by hot water and steam at Larderel10, Italy. By 1818, boric acid was being commercially extracted with several factories being built in the area for this purpose by the mid 1800's. In New Zealand, the Tasman Pulp and Paper Company uses approximately 18 tons of steam per hour for timber drying, black liquor evaporation, and pulp and paper drying (Wilson, 1974). In Iceland, a diatomacous slurry, dredged from Lake Myuata is dried in large rotary drum dryers using geothermal energy (Lindal, 1974). In Klamath Falls, Oregon, Medo-Bel Creamery pasteurizes milk using the heat from geothermal fluids (Belcastro, 1978). Geothermal Food Processing located at Brady Hot Springs, Nevada uses high temperature geothermal resources for the dehydration of onions and other vegetables. SEveral other facilities are presently being built or planned which will use geothermal resources for a number of industrial processes, most notably the production of alcohol.

\section{B. Space Conditioning}

The greatest near-term potential for the direct utilization of geothermal resources lies in the field of space heating and cooling. Space conditioning with geothermal water at temperatures below $100^{\circ} \mathrm{C}\left(212^{\circ} \mathrm{F}\right)$ could account for nearly 50 percent of the total resource utilization below $149^{\circ} \mathrm{C}\left(300^{\circ} \mathrm{F}\right)$. The usable temperature range for space conditioning is from $10^{\circ} \mathrm{C}\left(50^{\circ} \mathrm{F}\right)$ to $100^{\circ} \mathrm{C}\left(212^{\circ} \mathrm{F}\right)$ (Figure 13). Space conditioning can take the form of either a single well supplying an individual user or group of users or through the formation of geothermal heating districts where geothermal fluids are made available to users much as natural gas is now available.

Space Heating and Cooling with Geothermal Fluids

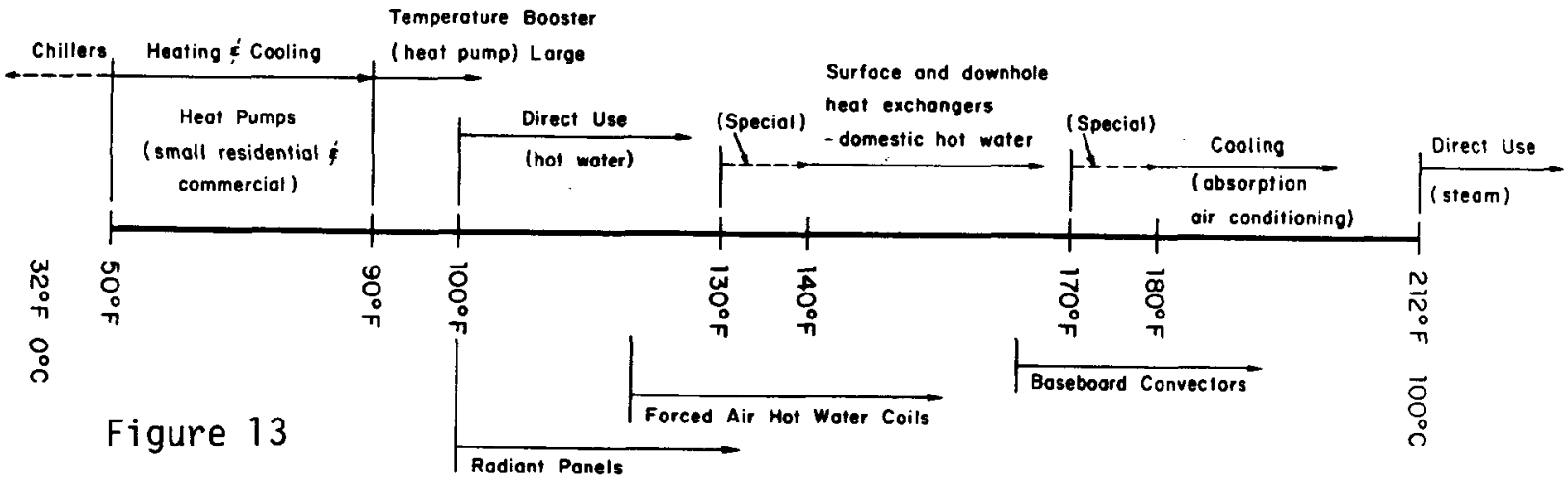

The district-heating system in Reykjavik, Iceland is probably the best known example of the use of geothermal energy for space conditioning. The system supplies some 15,600 homes and apartments which houses 97 percent of the population of over 113,000 (Lienau 1980). In the Reykjavik system, geothermal fluids are transported to the city by large capacity pipes from a series of wells situated about 19 miles from the 


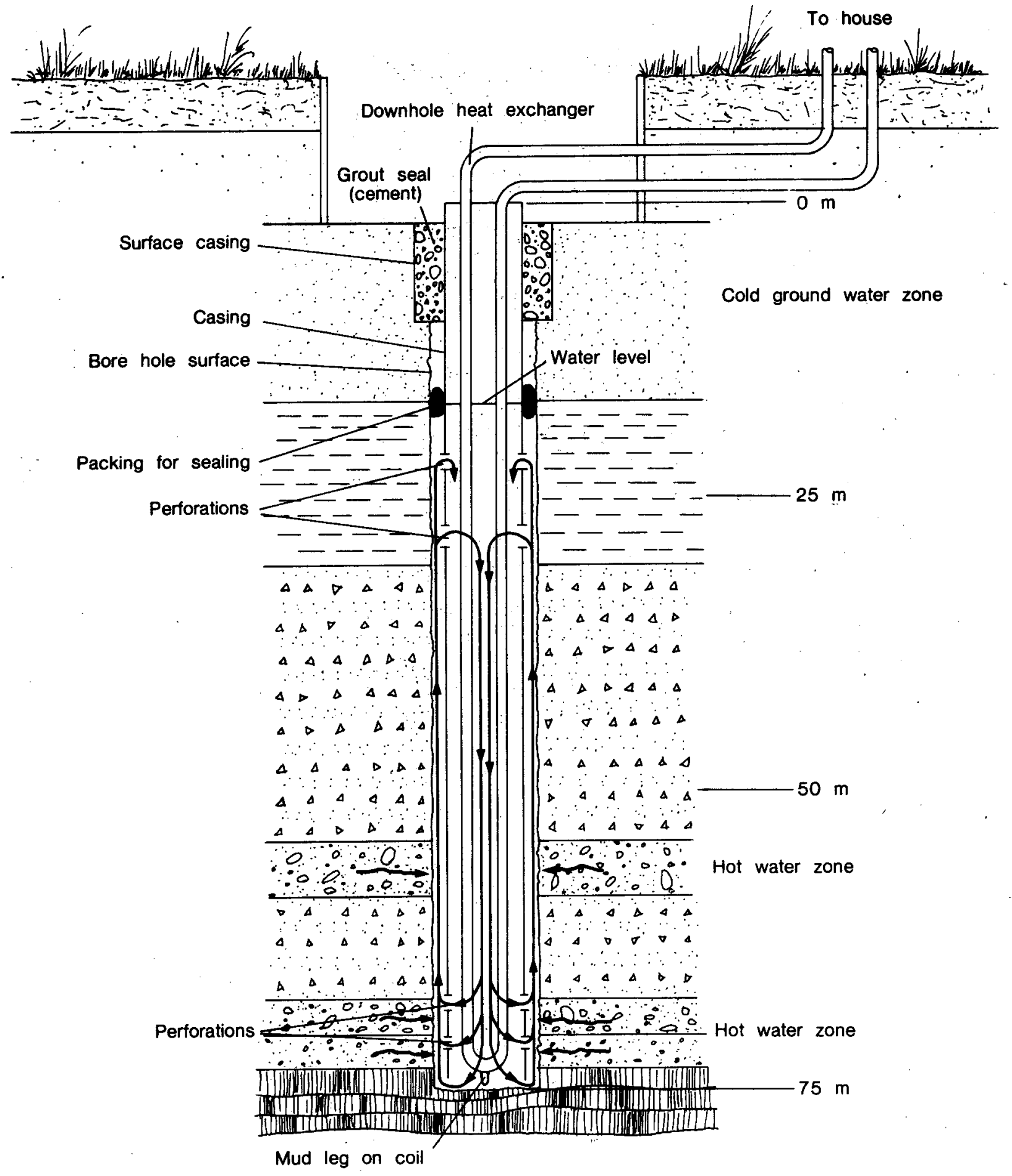

Typical downhole heat exchanger installation (not to scale)

Figure 14 
city. Large storage tanks located near the city are used in order to meet varying flow demands. The system which is designed to meet the base heating load of the city uses fossil-fuel fired boilers to boost the temperature of the geothermal water for periods of peak heating demand. The water which is transmitted from the storage tanks to individual users by a network of small diameter pipes, enters each residence through a valve sized to meet the heating demand of that unit and heating costs are based on the size of the valve. (Lund, 1977).

Presently, geothermal district heating systems are being constructed in Klamath Falls, Oregon and Boise, Idaho.

In Klamath Falls, Oregon, there are presently over 500 homes heated geothermally utilizing a single well to heat a single residence. A typical residential heating system in Klamath Falls (Figure 14) consists of a 10 inch diameter well with an average depth of 300 feet which is cased to depth with eight inch diameter steel casing. The casing is perforated at the hot water $10^{\circ} \mathrm{C}$ to $96^{\circ} \mathrm{C}\left(140^{\circ} \mathrm{F}\right.$ to $\left.205^{\circ} \mathrm{F}\right)$ zones and just below the static water level to allow natural circulation of the geothermal water between the annulus and the casing. Two downhole heat exchangers are then placed in the well--a two inch diameter loop for the heating system and a three-quarter inch diameter loop for domestic hot water. City water is fed into the heating loop and circulated through a forced-air system, baseboard convectors, or radiant panels for space heating (Figure 15) (Lund, 1978). City water is also circulated through the three-quarter inch loop to supply all domestic hot water needs.
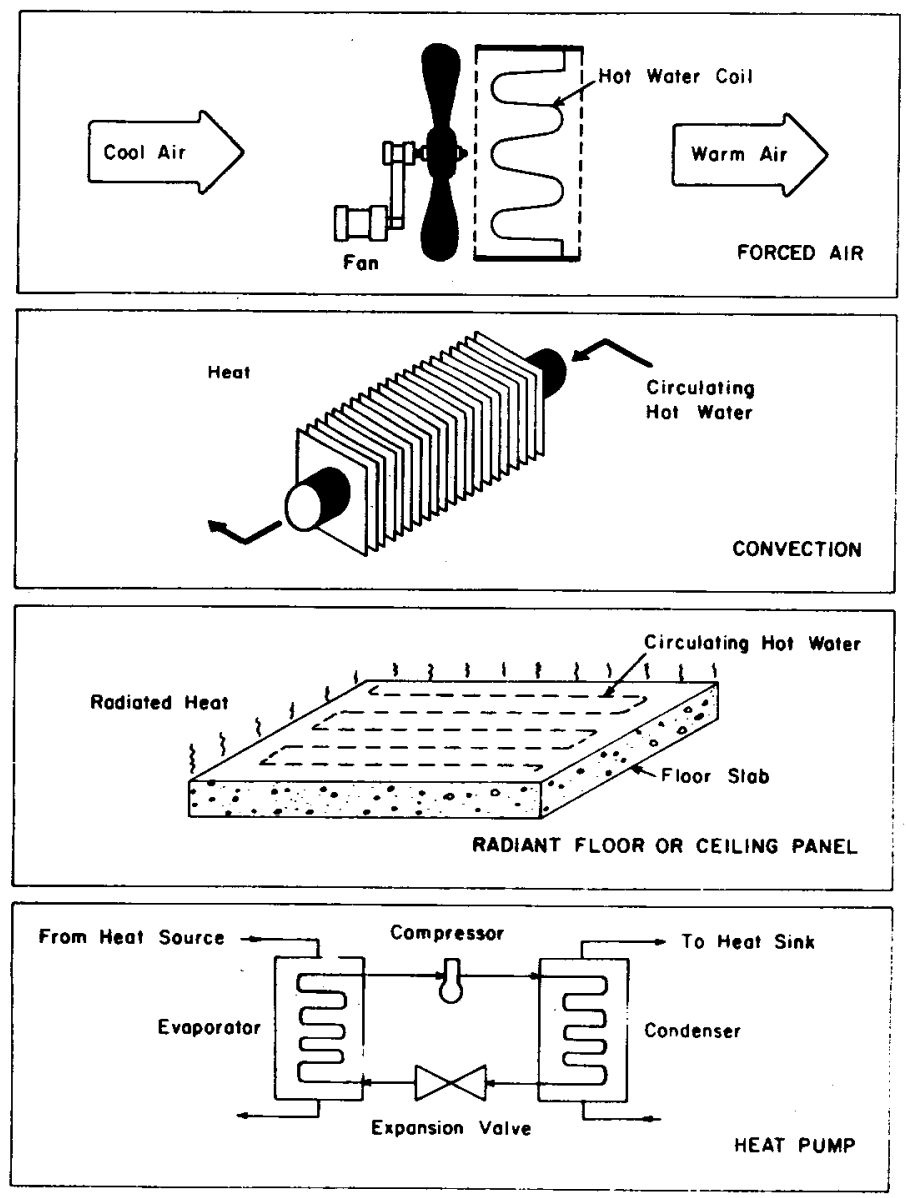

Figure 15

Typical Heat Convectors and Heat Pump 


\section{Agriculture and Aquaculture}

Agriculture and aquaculture-related uses generally require the lowest temperature geothermal resources. Typically temperatures between $27^{\circ} \mathrm{C}$ and $82^{\circ} \mathrm{C}\left(80^{\circ} \mathrm{F}\right.$ to $\left.180^{\circ} \mathrm{F}\right)$ will meet the requirements of agriculture and aquaculture production and processing (Figure 16).

Today, of the 7,000 megawatts thermal (MWt) which are pro'ided by geothermal resources, approximately 5,500 MWt are used in agriculture, aquaculture, and animal husbandry (Lienau, 1980). The Soviet Inion is the leader in the use of geothermal resources for agriculturally related activities with Hungary in second place. Unfortunately, very little has been published concerning the utilization of geothermal resources in the Soviet Union.

In Hungary over 13 million square feet of greenhouses are heated geothermally. Many of the greenhouses are built on rollers so that they can be easily moved, for ground cultivation and preparation using large equipment, and then returned to position.

In Japan, geothermally heated greenhouses used for the growing of flowers and vegetables cover over 157,000 square feet. Many of the greenhouses are operated as tropical gardens for sightseeing purposes. In addition, the Japanese are utilizing geothermal energy in poultry raising and the breeding and raising of carp and eels. A more exotic use is the raising of alligators and crocodiles, although the reptiles are bred purely for sightseeing purposes (Lienau, 1980).

The Geo-Products Corporation greenhouse operation, near Susanville, California, is the largest in the United States. At present 30 greenhouses are being used for the hydroponic raising of tomatoes and cucumbers. The operation which is totally geothermally heated, is expected to expand to over 200 units. Near Buhl, Idaho, Fish Breeders of Idaho are raising channel catfish at the rate of 500,000 pounds per year in $32^{\circ} \mathrm{C}\left(90^{\circ} \mathrm{F}\right)$ water (Lienau, 1980).

Research is being conducted at the Oregon Institute of Technology GeoHeat Utilization Center on the culture of giant prawns (Macrobrachium rosenbergi) in waste water from the institute's geothermal heating system. The waste water is also used in an experimental greenhouse, thus allowing for the evaluation of multi-stage use of geothermal resources and the economic benefits to be derived from cascading. 


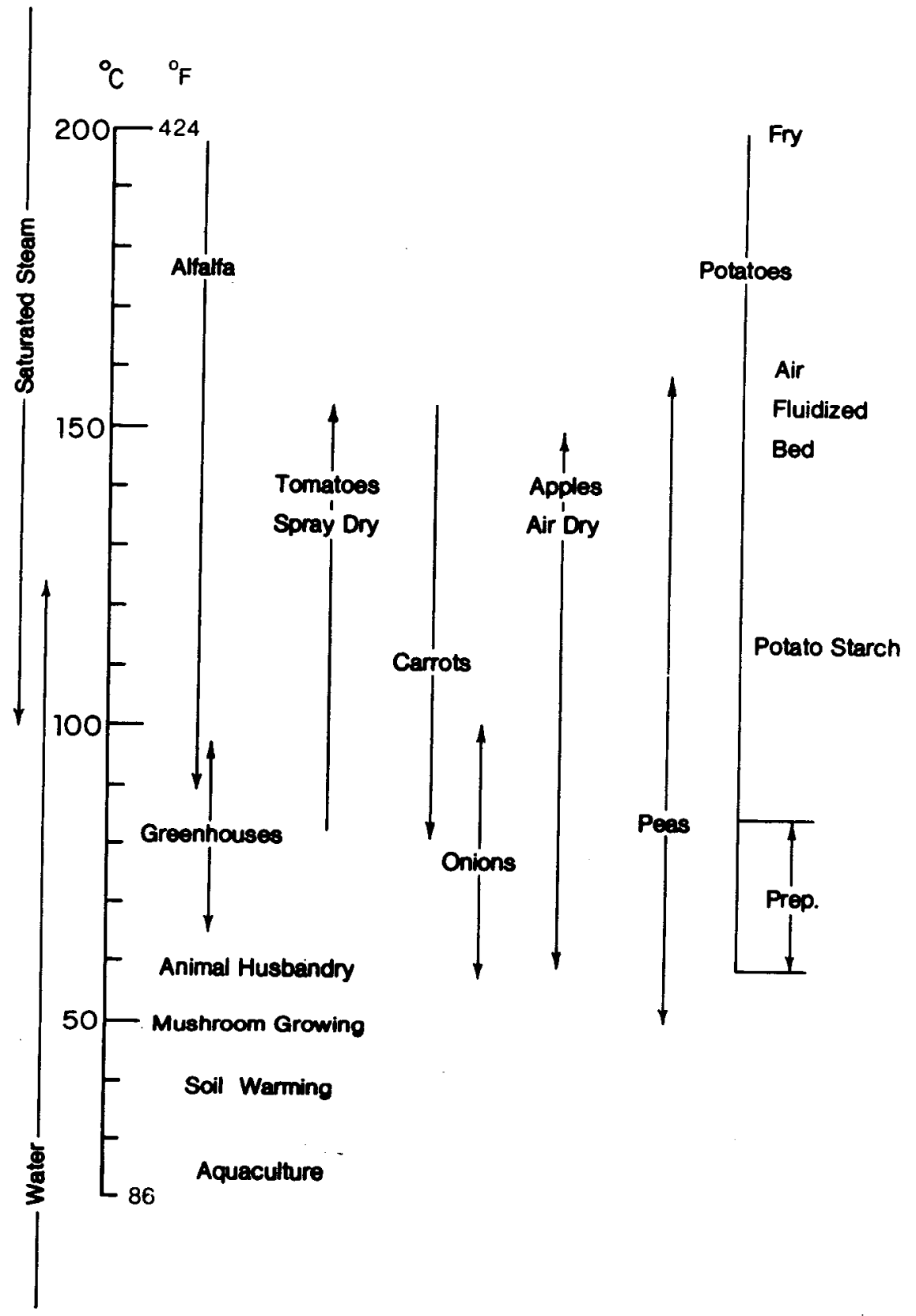

Agricultural uses for geothermal resources

Figure 16 


\section{INDIRECT UTILIZATION}

In many situations the direct use of geothermal resources may prove to be impossible or uneconomical. The temperature of the geothermat fluid available may be lower than that required for a desired application and/or the flow rate may be insufficient to meet the heating demand. In other instances it may be uneconomical to meet peak heating demands with a totally geothermal system due to requirements for large numbers of wells and large pipeline dimensions needed to meet those seal demands. Under any of the above circumstances, the use of auxiliary boilers or heat recovery systems (heat pumps) may prove technologically and economically attractive.

\section{A. Auxiliary Boilers}

Auxiliary boilers can be used to boost the temperature of geothermal fluids to meet peak demands or where the temperature of the geothermal resources is below that needed for a given application.

In Reykjavik, Iceland, the municipal heating system uses auxiliary fossil-fuel fired boilers to boost the $80^{\circ} \mathrm{C}\left(176^{\circ} \mathrm{F}\right)$ water to $110^{\circ} \mathrm{C}$ $\left(230^{\circ} \mathrm{F}\right)$ during the 15 to 20 coldest days of the year. Because of this capability, fewer wells and more economically demonstrated pipelines can be employed (Zoega, 1974). The use of auxiliary boilers can thus also serve as a back up system should problems arise with the primary geothermal system.

In the case of industrial processes which require high temperature water, the geothermal fluids can serve as preheated water which can be boosted to required temperatures using conventional boilers. This has been demonstrated to result in a substantial reduction in the use of fossil fuels as well as being economically sound.

Heat Recovery System

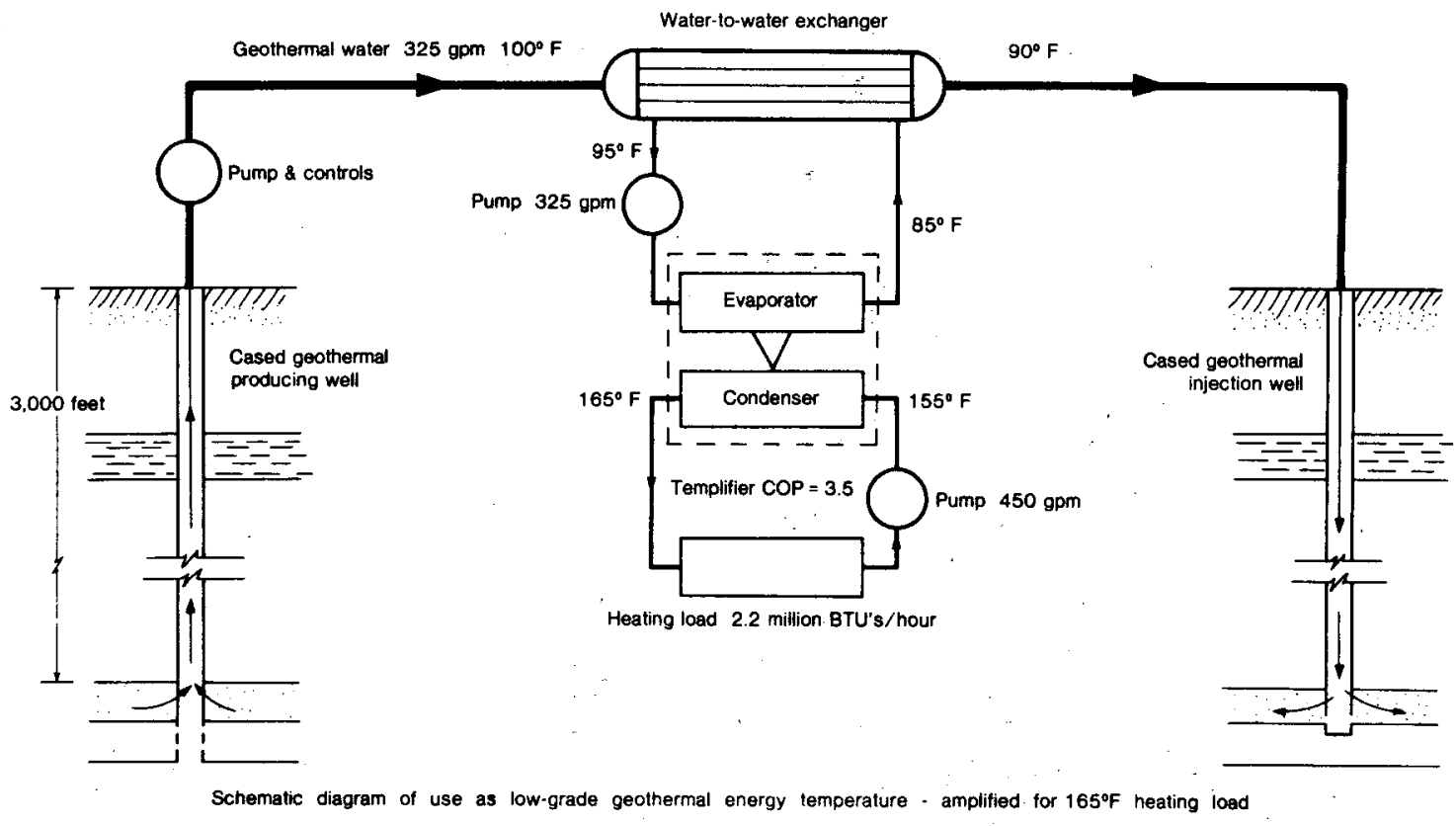

Figure 17 


\section{B. Heat Recovery Systems - Heat Pumps}

One of the most exciting developments in the use of low temperature geothermal resources is the development of water-to-water and water-toair heat pumps. The heat pump as pictured in Figure 17 can be utilized with water temperatures as $10 \mathrm{w}$ as $10^{\circ} \mathrm{C}\left(55^{\circ} \mathrm{F}\right)$. At the present time, the units are commercially available with output temperatures up to $110^{\circ} \mathrm{C}$ $\left(230^{\circ} \mathrm{F}\right)$. The heat recovery system extracts heat from the geothermal fluid, boosts the temperature, and finally transfers that heat to either a secondary fluid such as water or air. In the reverse mode, the waterto-air heat pump will provide air conditioning by extracting heat from the air and transferring that heat to water, which is then pumped into the ground. The principal advantage of the water heat pump in comparison to an air heat pump is the uniform temperature of the heat source or sink, thus allowing for much greater efficiency.

The energy savings which is known as the coefficient of performance (COP) is calculated by dividing the Btu output of the system by the Btu input to the system. The energy savings (COP) will rise with the temperature of the geothermal resource.

Several geothermal heat pump installations are presently in use. The largest use is in Criel, France where 4,000 dwellings are heated using low temperature geothermal fluids. The heat pumps are used to extract heat from the water returning from the first stage of the heating system. In this way the total amount of heat obtained from the geothermal resource is approximately double that which could otherwise be extracted (J.D. Garnish, 1978).

In Salt Lake City, Utah the 28 story office building of the Church of Jesus Christ Latter-day Saints is totally space conditioned using a water-to-air heat recovery system.

The firm of Burmeister and Wain located in Copenhagen, Denmark has recently developed the technology needed to produce heat pumps for use in municipal district heating systems. This development may allow for the construction of geothermal district heating systems in many areas where high temperature geothermal resources exist only at commercially unacceptable depths.

For a more detailed account of the direct and indirect use of geothermal resources for industrial processing, space conditioning, and agriculture and aquaculture, the reader is referred to the Geothermal Resource Council's Special Report No. 7, Direct Utilization of Geothermal Energy: A Technical Handbook. 


\section{SELECTED REFERENCES}

Anderson, D.N. and Lund, J.W., eds., 1980, Direct Utilization of Geothermal Energy-A Technical Handbook: Geothermal Resources Council Special Report No. 7, Davis, California.

Belcastro, E., 1978, Geothermally pasteurized milk process: proceedings Direct Utilization of Energy - A Symposium, Geotherm 1 Resources Counci1, Davis, California, p. 103-i04.

Garnish, J.D., 1978, Progress in geothermal energy: Endeavour, New Series v. 2, no. 2, p. 66-71.

Koenig, J.B., 1973, Worldwide status of geothermal resources development: Geothermal Energy, edited by Kruger and Otte, Stanford University Press, Stanford, California, p. 15-58.

Kruger, P. and Otte, C., eds., 1973, Geothermal Energy - Resources, Production, Stimulation: Stanford University Press, Stanford, California, $360 \mathrm{p}$.

Lienau, P.J., ed., 1978, Agribusiness Geothermal Energy Utilization Potential of Klamath and western Snake River Basins, Oregon: GeoHeat Utilization Center, Oregon Institute of Technology, Klamath Falls, Oregon, $180 \mathrm{p}$.

Lienau, P.J., 1980, Geothermal Resource Utilization: presentation to AAAS Annual Meeting, $4 \mathrm{p}$.

Lienau, P.J. and Lund, J.W., eds., 1974, Multipurpose Use of Geothermal Energy: proceedings of the International Conference on Geotherma 1 Energy for Industrial, Agricultural, and Commercial - Residential Uses, Oregon Institute of Technology, Klamath Falls, Oregon, 239 p.

Lindal, B., 1974, Geothermal energy for process use: Multipurpose Use of Geothermal Energy: proceedings of the International Conference on Geothermal Energy for Industrial, Agricultural and Commercial Residential Uses, Oregon Institute of Technology, Klamath Falls, Oregon.

Lund, J.W., 1977, Geothermal energy in Iceland: USDI - Geological Survey Report, Oregon Institute of Technology, Klamath Falls, Oregon.

Lund, J.W., 1978, Geothermal energy utilization for the homeowner: Oregon Institute of Technology, Klamath Falls, Oregon (prepared for the Oregon Department of Energy), 29 p.

Petersen, B., 1980, Large Diesel Driven Heat Pumps for District Heating: Burmeister and Wain, Copenhagen, Denmark.

Petroleum Information Corporation, 1979, The Geothermal Resource: Denver, Colorado. 
Reistad, G.M.; Schmisseur, W.E.; Shay, J.R. and Fitch, J.B., 1978, An evaluation of uses for low to intermediate temperature geothermal fluids in the Klamath Basin, Oregon: Bulletin No. 55, Oregon State University, Engineering Experiment Station.

Ryback, L., 1979, Urban heating from geothermal aquifers in the Paris Basin: proceedings, A Symposium on Geothermal Energy and its Direct Uses in the Eastern United States, Geothermal Resources Council Special Report, No. 5, Davis, California.

Wahl, E.F., 1977, Geothermal Energy Utilization: A Wiley-Interscience Publication, John Wiley and Sons, New York, 302 p.

Wi1son, R.D., 1974, Use of geothermal energy at Tasman Pulp and Paper Company Limited - New Zealand - Multipurpose Use of Geothermal Energy: proceedings of the International Conference on Geothermal Energy for Industrial, Agricultural, and Commercial - Residential Uses, Oregon Institute of Technology, Klamath Falls, Oregon.

Zoega, J., 1974, The Reykjavik municipal district heating system Multipurpose Use of Geothermal Energy: proceedings of the International Conference on Geothermal Energy for Industrial, Agricultural, and Commercial - Residential Uses, Oregon Institute of Technology, Klamath Falls, Oregon. 
Blank

$-52-$ 


\section{ECONOMIC FACTORS OF DIRECT USE PROJECTS}

Once a geothermal resource has been geologically proven and the technical feasibility of a project confirmed, an economic analysis is undertaken. Economic analysis is a series of calculations which determine the annual cash flows of alternative energy scenarios in order to select the one which is most attractive in terms of return on investment and cost per unit of energy produced. Ultimately, the decision to invest capital in a geothermal project hinges on the project's ability to accrue annual savings over the current fuel system, taking into account the project life, maintenance costs, cost of capital, fuel price projections and other factors.

Geothermal energy requires a relatively large capital investment at the beginning of a project, with small annual operating costs thereafter. The initial capital costs for a small district heating system, attributable to production wells, pipelines, heat exchangers, possible injection wells, and various other items, may run as high as several million dollars. By contrast, the initial investment to provide natural gas heat to the same district would include only the cost of a central boiler and distribution lines. After that, the operating and maintenance costs for the two systems may be comparable, while the natural gas users must continually pay for their fuel, the geothermal users have no fuel costs at all. Thus, two systems with fundamentally different cost structures must be compared. The economic analysis must show whether or not the smaller annual cost and larger initial capital investment for the geothermal project is cheaper overall than the conventional fuel system.

A major problem with economic analyses of alternative energy systems stems from the fact that energy price forecasting is often speculative and unreliable. Furthermore, different forms of energy escalate at different rates. Forecasts of conventional fuel costs are available through numerous government agencies, trade associations and even private firms. The annual inflation rates used at the Geo-Heat Utilization Center at the Oregon Institute of Technology (OIT) over the past three years are 12.2 percent for nautral gas, 9.5 percent for electricity, and 8.5 percent for $0 i 1$. Naturally, assumptions of high rates of escalation of conventional fuel prices improve the relative economic feasibility of geothermal projects. Thus, OIT's inflation rates, have proven to be grossly understated, which means that all the geothermal projects evaluated over this three year period have a higher degree of feasibility than anticipated. Economic analyses consist of the following steps:

1. A. In the case of a system that is currently operating on conventional fuels, collect historical annual energy costs for that portion of the energy load that is to be converted to geothermal.

$B$. In the case of a new development where historical fuel consumption data is not available, estimate the capital investment and installation costs of the conventional fuel system, the energy load, and current cost of conventional fuel. 
2. Obtain conservative escalation rates for conventional fuels over the life of the project.

3. Estimate the capital investment and installation costs of the geothermal system.

4. Estimate the annual operation and maintenance costs for both the conventional and the geothermal systems, projected with appropriate escalation rates over the life of the project.

5. Consider the effects of investment tax credits, depreciation, write-offs, and depletion allowances for both systems.

Table III is a guide to the cost data that should be considered in a feasibility study.

In effect, two alternatives are being evaluated. Alternative one is the system which used conventional fuel, calculating a series of annual cash flows over the estimated life of the project. Alternative two is the geothermal system with annual cash flows calculated over the life of the project. The annual cost of the geothermal system is subtracted from the annual costs of the conventional system, and the resulting net cash flows will indicate the annual savings or expenses resulting from the geothermal system as opposed to a conventional system.

In attempting to justify the capital investment of a geothermal system, the time value of money must be considered. The concept of the time value of money simply states that savings or revenues received at some future date are of less value than savings or revenues received today. For example, a series of annual savings of $\$ 10,000$ per year projected over the next 20 years would have a present value of $\$ 851,000$ if the cost of capital were 10 percent annually. For a 20-year project, the projected annual cost of each system would be forecast for each year and the net cash flow, which is the difference between the two systems, would be discounted back to the present worth using either the cost of capital or the minimum attractive rate of return. If the calculated present worth in favor of the geothermal project was equal to or greater than the additional capital investment required for the geothermal project, the project is economically feasible. If the calculated present worth of the savings resulting from the geothermal project is less than the additional investment required for the geothermal system, then the project is not economically feasible.

Figure 18 compares the annual costs of a conventional system versus a geothermal system. Notice that the total cost of the conventional system is less than the total cost for the geothermal system in the early years of the project. As the annual operating expenses of the conventional system increase more rapidly than the geothermal system, the two systems reach a point where annual operating costs are equal and from that time forward the geothermal system has lower total annual costs.

Another frequently used approach to cost analys is is to determine the "payback period". Payback simply sums the annual cash flows from the project to determine when the initial capital investment will be recovered (paid back). Virtually all direct use geothermal projects 
TABLE III

BASICS OF ECONOMIC ANALYSIS

When performing economic feasibility studies for geothermal applications, the following data are required:

I. Capital Investment of the Geothermal System

A. Wells and Well-head Equipment

1. Production wells

2. Production well pumps

3. Well-head buildings

4. Power hook-up and controls

B. Piping Network

1. Primary supply pipeline
a. Excavation, bedding and backfill
b. Concrete tunnels where applicable
c. Pipeline
d. Fittings
e. Insulation
f. Installation
g. Special costs such as highway crossings, railroad crossings, riverbed crossings, etc.

2. Secondary distribution systems
a. Excavation, bedding and backfill
b. Concrete tunnels where applicable
c. Pipeline
d. Fittings
e. Insulation
f. Installation

C. Heat Exchanger System

1. Heat exchanger

2. Circulation pumps

3. Heat exchanger building

4. Control system and power hook-ups

5. Other equipment
a. Expansion surge tanks
b. Flashers
c. Reservoirs, etc.

D. Retrofit costs

1. Piping

2. Heat exchangers
a. Fan coil units
b. Convectors 
TABLE III cont.

3. Controls and hook-up

4. Other special equipment required

E. Overhead costs

1. Engineering

2. Contingencies

3. Other

II. Annual Costs of the Geothermal System

A. Operating costs

1. Power requirements (kilowatt hours plus cost per kwh)

a. Pumping

b. Circulation

c. Controls

d. Operating personnel salaries

2. Operator's salaries

3. Other

a. Billing

B. Maintenance costs

1. Periodic maintenance

a. Wells

b. Pipelines

c. Heat exchangers

d. Pumps

2. Maintenance personnel salaries

3. Shops

III. Costs of Conventional System

A. Capital investment (for existing conventional systems this cost would be zero)

B. Annual operating costs

1. Units required in kwh, gallons of oil, tons of coal, or cubic feet of natural gas, etc., and cost per unit

2. Salaries

3. Other

C. Annual maintenance cost

1. Periodic maintenance

2. Salaries

3. Shops 


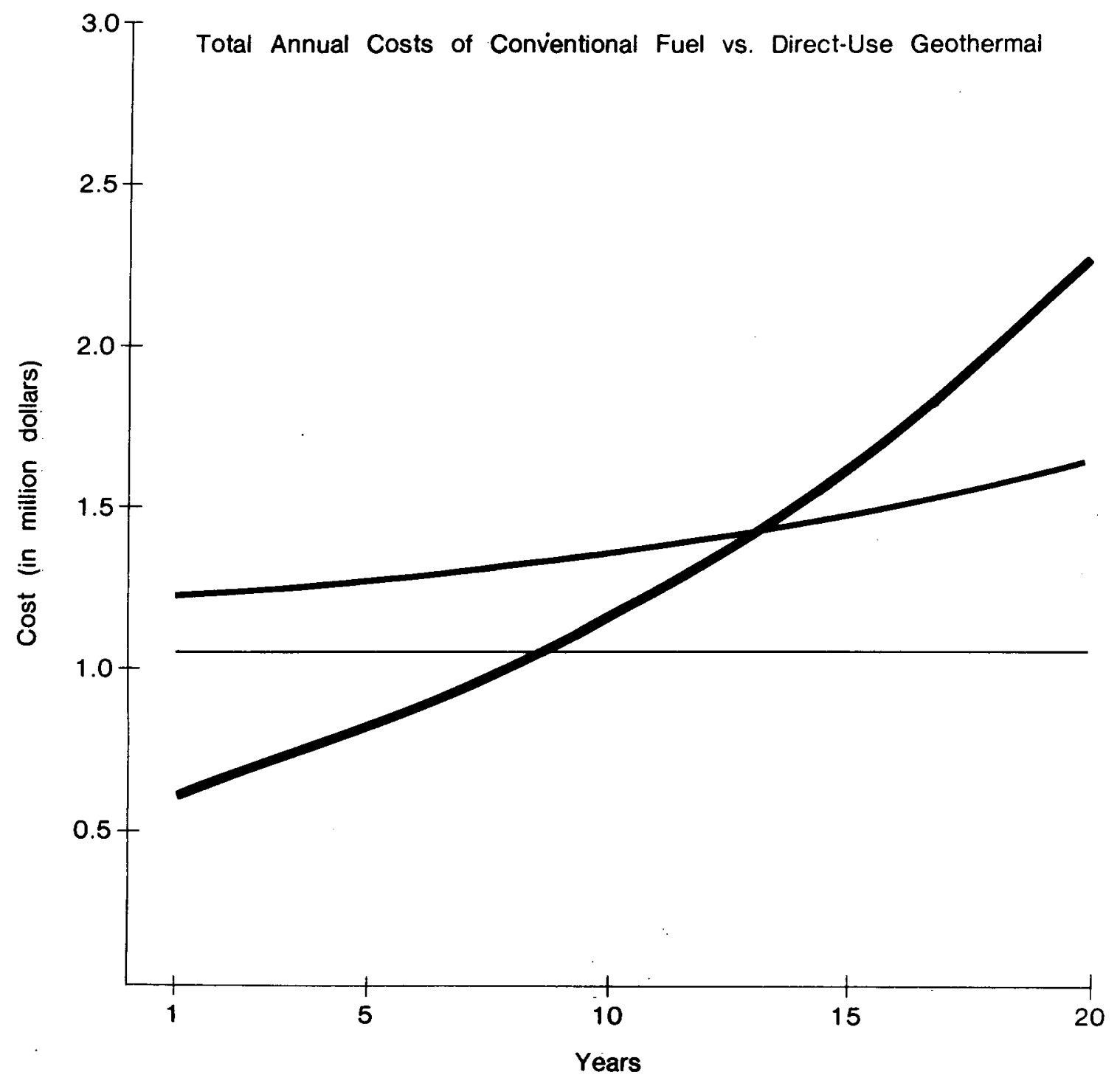

Geothermal Annual Cost

\section{Geothermal Capital Investment Amortized}

Conventional Fuel Costs

Figure 18

$-5 \%$ 
require a large capital investment and operate at a loss during the early years of the project life. Nonetheless, with economic lives in excess of 20 years, most can pay back the initial capital investment many times over during the life of the project.

One problem with this type of analysis is that it does not take into account the time value of money. Many investors have limited funds and may try to invest over as short a time period as possible. Other investors are anticipating opportunities in the near future and want to retrieve their investment by some deadline. Often times small businesses lacking sufficient working capital are reluctant to invest these 1 imited funds for long time periods.

Payback analysis also ignores total project life. For example: Project A requires a $\$ 100,000$ investment and will pay $\$ 25,000$ per year for five years. The interest rate of this project is approximately 8 percent. The payback is four years $(4 \times \$ 25,000)$. Project $B$ requires a $\$ 100,000$ investment and pays $\$ 15,000$ per year for 20 years. Based on the payback criteria, the investor would select project $A$, while project $B$ is far superior.

Table IV presents the 20-year cash flows for a district heating system developed by a municipality. The city wants to develop a geothermal heating system to provide heat for two schools, city hall, city shops, fire station, and the post office. These buildings were being heated by electricity, heating oil, and propane. The cost of the system was estimated to be $\$ 837,700$. The city hopes to finance this project with 8 percent tax-free municipal bonds paying interest annually and maturing in 20 years, and the city will be able to reduce their heating costs drastically over this time period. The project pays for itself in the 20 year period and has an excess present value at 8 percent of $\$ 239,539$.

Table $V$ presents the same data for an identical system, but assumes that a geothermal developer drilled the wells and installed the system selling the energy to the city at the same price as the city was currently paying for conventional fuel. The gross sales column is a composite of all conventional fuels used, inflated at their projected inflation rates over a 20-year period. Columns 2 and 3 apply depletion allowances and 10 year straight-line depreciation assuming the developer has numerous ongoing projects and can take advantage of these tax write-offs. Column 4 combines the electrical pumping costs and the system maintenance costs. Federal taxes are based on the assumption that the corporation is in a 48 percent effective tax bracket and can write-off losses against other income.

The second portion of Table $V$ presents an after tax cash flow of the project which includes an investment tax credit taken in the first year of $\$ 209,425$. When evaluated at 7 percent, the cash flows, indicate that $\$ 1,179,442$ could be spent today on this project. The discounted cash flow at 12.22 percent indicates that the corporation would earn this rate after taxes. It is doubtful that the city would agree to pay conventional fuel rates for the next 20 years. It should also be emphasized on this particular project that retrofit costs were not considered for the individual buildings. 


\begin{tabular}{|c|c|c|c|c|c|c|}
\hline $\begin{array}{c}\text { TOTAL } \\
\text { PRESENT } \\
\text { ELECTRICAL } \\
\text { COST } \\
\end{array}$ & $\begin{array}{r}\text { TOTAL } \\
\text { PRESENT } \\
\text { OIL COST } \\
\end{array}$ & $\begin{array}{c}\text { GEOTHERMAL } \\
\text { PUMPING } \\
\text { COSTS } \\
\end{array}$ & $\begin{array}{l}\text { GEOTHERMAL } \\
\text { OPERATION \& } \\
\text { MAINTENANCE } \\
\text { COSTS } \\
\end{array}$ & $\begin{array}{l}\text { BOND } \\
\text { INTEREST } \\
\text { AT } 8 \% \\
\end{array}$ & $\begin{array}{l}\text { ANNUAL } \\
\text { CASH } \\
\text { FLOW } \\
\end{array}$ & $\begin{array}{l}\text { PRESENT } \\
\text { VALUE } \\
\text { AT } 8 \% \\
\end{array}$ \\
\hline $\begin{array}{l}\operatorname{COST} \\
32244 .\end{array}$ & $\begin{array}{c}\text { COST } \\
28530 .\end{array}$ & $\begin{array}{l}\text { COST } \\
2436 .\end{array}$ & $\begin{array}{l}\text { COST } \\
10000 .\end{array}$ & $\begin{array}{l}\text { COST } \\
67016 .\end{array}$ & S/YR & $\begin{array}{l}\text { P.W. } \\
8 .\end{array}$ \\
\hline $\begin{array}{c}35308 . \\
38662 . \\
42335 . \\
46357 . \\
50760 . \\
55583 . \\
60352 . \\
65530 . \\
71152 . \\
77257 . \\
83886 . \\
91083 . \\
98898 . \\
107384 . \\
116597 . \\
126601 . \\
137464 . \\
149258 . \\
162064 . \\
175969 .\end{array}$ & $\begin{array}{c}30955 . \\
33586 . \\
36441 . \\
39539 . \\
42899 . \\
46546 . \\
50502 . \\
54795 . \\
59452 . \\
64506 . \\
69989 . \\
75938 . \\
82393 . \\
89396 . \\
96995 . \\
105239 . \\
114185 . \\
123890 . \\
134421 . \\
145847 .\end{array}$ & $\begin{array}{r}2667 . \\
2921 . \\
3198 . \\
3502 . \\
3835 . \\
4199 . \\
4559 . \\
4951 . \\
5375 . \\
5837 . \\
6337 . \\
6881 . \\
7472 . \\
8113 . \\
8809 . \\
9564 . \\
10385 . \\
11276 . \\
12244 . \\
13294 .\end{array}$ & $\begin{array}{l}10700 . \\
11449 . \\
12250 . \\
13108 . \\
14026 . \\
15007 . \\
16058 . \\
17182 . \\
18385 \\
19672 \\
21049 . \\
22522 . \\
24098 . \\
25785 . \\
27590 . \\
29522 . \\
31588 . \\
33799 . \\
36165 . \\
38697 .\end{array}$ & $\begin{array}{l}67016 . \\
67016 . \\
67016 . \\
67016 . \\
67016 . \\
67016 . \\
67016 . \\
67016 . \\
67016 . \\
67016 . \\
67016 . \\
67016 . \\
67016 . \\
67016 . \\
67016 . \\
67016 . \\
67016 . \\
67016 . \\
67016 . \\
67016 .\end{array}$ & $\begin{array}{r}-14121 . \\
-9138 . \\
-3689 . \\
2269 . \\
8783 . \\
15906 . \\
23221 . \\
31176 . \\
39829 . \\
49239 . \\
59473 . \\
70602 . \\
82705 . \\
95866 . \\
110177 . \\
125738 . \\
142659 . \\
161057 . * \\
181060 . \\
-634891 .\end{array}$ & $\begin{array}{r}-13075 \\
-7834 \\
-2928 \\
1668 \\
5978 \\
10023 \\
13549 \\
16844 \\
19924 \\
22807 \\
25507 \\
28037 \\
30410 \\
32639 \\
34732 \\
36702 \\
38556 \\
40304 \\
41954 \\
-136215\end{array}$ \\
\hline & & & & & 537920 . & 239582 \\
\hline
\end{tabular}



GEOTHERMAL DEVELOPMENT CORPORATION

\begin{tabular}{|c|c|c|c|c|c|c|}
\hline $\begin{array}{c}\text { ADD } \\
\text { DEPLETION } \\
\text { AND DPRCN. } \\
\end{array}$ & $\begin{array}{l}\text { AFTER TAX } \\
\text { CASH FLOW } \\
\text { INCLUDES } 25 \% \\
\text { INVESTMENT } \\
\text { TAX CREDIT } \\
\end{array}$ & $\begin{array}{l}\text { PRESENT } \\
\text { VALUE } \\
\text { AT } 7 \% \\
\end{array}$ & $\begin{array}{l}\text { PRESENT } \\
\text { VALUE } \\
\text { AT } 12.22 \% \\
\end{array}$ & $\begin{array}{c}\text { ANNUAL } \\
\text { EQUIVALENT } \\
\text { CASH FLOW } \\
\text { PROVIDED BY } \\
\text { THE PROJECT } \\
\end{array}$ & $\begin{array}{l}\text { ANNUAL } \\
\text { CASH FLOW } \\
\text { DEDUCTING } \\
\text { ROI } \\
\end{array}$ & $\begin{array}{l}\text { PRESENT } \\
\text { VALUE } \\
\text { AT } 11.8788 \%\end{array}$ \\
\hline $\begin{array}{l}89971 . \\
89843 . \\
89573 . \\
89136 . \\
89442 . \\
90712 . \\
92021 . \\
93442 . \\
94984 . \\
96658 . \\
23081 . \\
25053 . \\
27194 . \\
29517 . \\
32039 . \\
34776 . \\
37748 . \\
40973 . \\
44473 . \\
48273 .\end{array}$ & $\begin{array}{r}280117 . \\
73221 . \\
75925 . \\
78814 . \\
82348 . \\
86661 . \\
91093 . \\
95912 . \\
101152 . \\
106848 . \\
76853 . \\
83587 . \\
90908 . \\
98867 . \\
107519 . \\
116925 . \\
127150 . \\
138265 . \\
150347 . \\
163480 .\end{array}$ & $\begin{array}{r}261791 . \\
63954 . \\
61978 . \\
60127 . \\
58713 . \\
57746 . \\
56728 . \\
55822 . \\
55020 . \\
54316 . \\
36512 . \\
37114 . \\
37724 . \\
38342 . \\
38970 . \\
39607 . \\
40252 . \\
40908 . \\
41572 . \\
42246 .\end{array}$ & $\begin{array}{c}249614 . \\
58143 . \\
53725 . \\
49696 . \\
46270 . \\
43391 . \\
40644 . \\
38134 . \\
35838 . \\
33734 . \\
21622 . \\
20955 . \\
20309 . \\
19682 . \\
19074 . \\
18483 . \\
17911 . \\
17356 . \\
16817 . \\
16295 .\end{array}$ & $\begin{array}{l}111299 . \\
111299 . \\
111299 . \\
111299 . \\
111299 . \\
111299 . \\
111299 . \\
111299 . \\
111299 . \\
111299 . \\
111299 . \\
111299 . \\
111299 . \\
111299 . \\
111299 . \\
111299 . \\
111299 . \\
111299 . \\
111299 . \\
111299 .\end{array}$ & $\begin{array}{l}168817 \\
-38078 \\
-35374 \\
-32486 \\
-28951 \\
-24638 \\
-20206 \\
-15387 \\
-10148 \\
-4451 \\
-34446 \\
-27712 \\
-20391 \\
-12433 \\
-3780 \\
5626 \\
15851 \\
26965 \\
39048 \\
52181\end{array}$ & $\begin{array}{c}250375 . \\
58498 . \\
54218 . \\
50305 . \\
46980 . \\
44192 . \\
41519 . \\
39074 . \\
36833 . \\
34777 . \\
22358 . \\
21735 . \\
21129 . \\
20539 . \\
19965 . \\
19406 . \\
18863 . \\
18334 . \\
17819 . \\
17318 .\end{array}$ \\
\hline & TOTALS & 1179442 . & 837693. & & 5. & 854239 . \\
\hline
\end{tabular}


Blank

$-62-$ 


\section{INTRODUCTION}

This chapter provides a general guide to the regulatory framework affecting geothermal energy development. Specific details of the permitting and approval process can be obtained from the appropriate federal, state, and local agencies. If geothermal development is to proceed expeditiously, the developer-user must effectively plan for compliance with regulations and permitting procedures.

The following sections outline the general steps necessary to gain access to explore, develop, distribute, and use geothermal resources.

\section{OBTAINING ACCESS TO GEOTHERMAL RESOURCES}

\section{A. Determining Resource Ownership}

After a site for geothermal resource development has been identified, land surface and subsurface ownership must be determined. In many cases, ownership of the surface and geothermal or mineral rights is the same. However, in some instances, the geothermal or mineral estates have been severed from the surface ownership. When the estates have been separated, the potential developer will have to negotiate with both owners.

In any case, a competent title search and ownership determination is essential to secure the necessary development rights. It is best to consult a qualified attorney.

The would-be geothermal developer must identify and secure all resource rights required for the proposed project. This task is not as simple as it may appear since geothermal resources are akin to water, to gases, and to minerals. This complexity makes it difficult to relate geothermal to other established resource categories. Existing water rights, mineral titles, surface and subsurface estates form an intricate tangle, and attachment of geothermal rights to one of them will disturb the rest.

Legal definitions of geothermal resources serve to distinguish geothermal resources from other natural resources, in particular: water, dissolved gases, and minerals.

It is important to consider the legal definitions of geothermal resources at the state and federal level. The federal Geothermal Steam Act of 1970 defines geothermal resources as:

"Geothermal steam and associated geothermal resources means (i) all products of geothermal processes, embracing indigenous steam, hot water and hot brines; ( $i i)$ steam and other gases, hot water and hot brines resulting from water, gas, or other fluids artificially 
introduced into geothermal formations; ( $i i j$ ) heat or other associated energy found in geothermal formations; and (iv) any by-product derived from them."

In establishing geothermal legislation, Oregon drew from the federal Geotnermal Steam Act of 1970 and the Cal ifornia Geothermal Resources Act of 1967. The Oregon definition is:
"Geothermal resource means the natural heat of the earth, the energy, in whatever form, below the surface of the earth present in, resulting from, or created by, or which may be extracted from the natural heat, and: all minerals in solution or other products obtained from naturally heated fluids, brines, associated gases, and steam, in whatever form, found below the surface of the earth, exclusive of helium or of $0 i 1$; hydrocarbon gas or other hydrocarbon substances, but including, specifically:
a. all products of geothermal processes, embracing indigenous steam, hot water brines;
b. steam and other gases, hot water and hot brines resulting from water, gas, or other fluids artifically introduced into geo- thermal formations;
c. heat or other associated energy found in geothermal forma- tions; and
d. any by-product derived from them."
(Oregon Revised Statutes (ORS) 522.005(7)

In adopting sections of both the California and federal definitions, the Oregon statute does not clearly articulate a resource characterization.

The Oregon Geothermal Resources Act of 1975 grants ownership rights of geothermal resources to the surface owner. The act states:

"Ownership rights to geothermal resources shall be in the owner to the surface property underlain by the geothermal resources unless such rights have been otherwise reserved or conveyed. However, nothing in this section shall divest the people or the state of any rights, title or interest they may have in geothermal resources."

$$
\text { (ORS 522.035) }
$$

Obviously there is confusion about the nature and ownership of geothermal resources. Therefore, the developer is advised to secure all resource rights, surface and subsurface, that may constitute a claim to geothermal resources.

B. Access and Development Rights

1. Private Land

Access to private land can be obtained by purchase, lease, permit, option, or any other mutual agreement with the owner of the surface 
property and geothermal estate. If the land and resources are purchased outright, it is important that the developer secure clear title to the surface and subsurface rights.

In most instances, access to private land is obtained through a geothermal lease. Leasing terms generally include length of lease, royalty payments, lease fees, and stipulations governing exploration and development activities. This mechanism is often based on $0 i 1$ and gas leasing procedures.

Landowners may permit access prior to a lease or purchase option. This allows the developer to conduct agreed upon preliminary exploration activities. Such activities could include geological and geophysical investigations which do not disturb the surface and temperature gradient hole drilling. A state well drilling permit would be required for exploratory drilling on private land.

If the area of interest is already under lease for other purposes such as farming or grazing, the developer must secure permission from the lessee for surface access rights.

Both the developer seeking access rights and the landowner interested in leasing resource title would be wise to invest in competent title assistance. In addition to this legal advice, consultation with a qualified accountant regarding royalty payments and applicable tax laws is advised.

\section{State Land}

The State Land Board, through the Division of State Lands, is authorized to issue leases for geothermal resources underlying state-owned lands. A geothermal resources lease is required to explore, develop or dispose of any state-owned geothermal resources.

However, casual exploration activities can be carried out before lease acquisition under a geothermal exploration permit issued by the Division of State lands. The procedure requires the applicant to submit a description of the exploration plan, evidence of compliance with insurance and bonding requirements and other information deemed necessary. The permit is used for a one year period and allows nonexclusive access to state land for geothermal exploration. An exploration permit does not give preferential right to lease.

To obtain a lease, application must be filed with the Division of State Lands with a nonrefundable $\$ 50$ fee and $\$ 1$ per acre advance rental fee for a minimum of 40 acres.

Generally, applications are accepted on a first come, first served basis, although the Division may favor an applicant with adjacent lands under lease. Leases may be issued by application or public drawing on noncompetitive land. The Division administers cash bonus bid leases (a bid per acre over and above the minimum rental fee) on competitive lands classified as a Designated Geothermal 
Resource Area based on geologic evidence and/or a producing geothermal well. To date, no areas have been so classified in Oregon.

To maintain lease application status, the applicant is required to submit, within 120 days of filing the application; a geologist's preliminary survey report and ground water report, environmental impact report, evidence of compliance with insurance requirements; corporate surety bond of at least $\$ 10,000$, copies of permits issued by state or local regulatory agencies, and any other information required by the Division of State Lands.

Preparation of the Environmental Impact Report (EIR) is the responsibility of the applicant. The following information is required:

- technical description of proposed geothermal operations

- common effects of all geothermal operations

- description of resources peculiar to the site involved

- possible means to mitigate adverse effects

The Division of State Lands has prepared a statement to meet the first two requirements, and has issued instructions for estimating environmental impact.

The pre-lease environmental report is required to address the potential effects of proposed exploration, development and production activities for the lease in terms of environmental and socioeconomic acceptability. The lease applicant pays for the assessment. Cost and time related to preparation of the EIR will vary depending on the scope of the proposed action.

The Division also requires: An archaeological survey before entry for exploration, proposed program for monitoring and surveillance of the geothermal resource and ground water quality and quantity during production, program for subsidence monitoring, revegetation for disturbed areas, and compliance with Department of Environmental Quality (DEQ) standards governing air and water quality, noise, and waste disposal.

When the assessment is complete, the Division circulates the application and environmental report to appropriate state agencies for comment. If no serious concerns arise, the application goes to the State Land Board for final approval.

The lease does not authorize construction of a power plant on state land.

The Land Board reserves the right to cancel or modify any geothermal lease, thereby authorizing the state to manage geothermal resource development on lands within its jurisdiction in an efficient manner for the benefit of the state. 
Salient features of the regulations covering leasing of state-owned land include:

Lease limitations

40 acres minimum.

No limitation on maximum lease size or total state holdings.

\section{Primary term}

Ten years.

\section{Lease renewal}

Leases may be renewed for up to an additional five years if a geothermal discovery has been made nearby or a discovery is deemed imminent by the Division director.

Leases may be renewed for an additional ten years if the royalties of any preceding year equal or exceed the annual rental rate.

Maximum lease term is fifty years, but lessee may have a first right of refusal.

Annual fees

Rental rates are:

$\$ 1$ per acre annually for the first three years

$\$ 3$ per acre for the fourth year

$\$ 5$ per acre for every year thereafter

Lease terms may be renegotiated. Annual rental is deducted from Production royalties in any given year once production has commenced.

Production Royalties

A royalty of ten percent of the gross value of the geothermal resource, one percent of the value of demineralized water, and five percent from the gross sale of by-product is paid to the State of Oregon.

\section{Information}

Rules and regulations governing the leasing of state land can be found in Oregon Revised Statutes Chapter 273 and Oregon Administrative Rules Chapter 141 Section 75. A copy of the application for geothermal resource lease is included as Figure 19. For additional information contact:

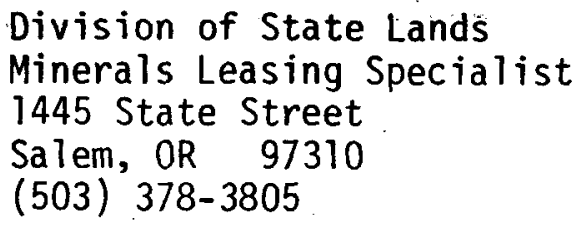


Tease in, upon and under the following State-owned land:

hereby applies for a geothermal
A. Township
Range
Section
W. M.

all in County, Oregon.

comprising approximately acres

B. The following persons are hereby designated for receipt of communications, as appropriate, under the geothermal lease:

1)

Oregon Agent

Street Address City $\quad$ State Zip Telephone Number

2)

other

C. Applicant certifies that it: () is a U. S. citizen

$($ ) is a firm, association, or corporation qualified to do business in Oregon

( ) is not at the date hereof, knowingly violating any State of Oregon laws or regulations

D. Approvals, permits and property rights have been obtained as follows: 
3. Federal Land

The major pre-lease activities of the federal leasing process are summarized in Figure 20.

Surface access and the right to explore, develop and use geothermal resources on federal lands are acquired with a geothermal lease issued by the U.S. Bureau of Land Management (BLM). Pursuant to the Geothermal Steam Act of 1970, the Secretary of the Interior can issue leases for the development and use of geothermal resources on certain federal lands. Exempted from leasing are lands within the National Park System, national recreation areas, fish hatcheries, identified wildlife areas (e.g., refuges, ranges, management areas, waterfowl production areas). Indian lands, Department of Defense lands, and other lands selected by the Secretary. Wilderness areas may be leased in accordance with terms of the Wilderness Act of 1964.

Limited exploration involving casual-use activities and other preliminary evaluation operations may be conducted before securing a lease by obtaining a temporary use permit from the local BLM District Office or the Forest Supervisor's Office. Casual use refers to activities such as geologic mapping that are transitory and do not appreciably disturb the land.

Pre-lease exploration activities including test drilling up to 152 meters (500 feet) may begin upon approval of a "Notice of Intent and Permit to Conduct Exploration Operations" from the District Manager of the BLM, who coordinates with the USGS. The notice requires site specific information concerning exploration plans and a $\$ 5,000$ bond or other bond assurance. The approved notice requires compliance with all applicable federal and state laws and local ordinances. When the exploration activities are complete, a "Notice of Completion of Exploratory Operations" must be filed with the BLM. Similar procedures are required by the U.S. Forest Service, which issues Prospecting Permits on National Forest Lands for exploratory operations.

Casual-use and exploration under a Notice of Intent gives the nonexclusive right to conduct operations on federal land, but no preference for a lease. A geothermal lease gives the exclusive right to drill for, develop, and use geothermal resources under the leased land and the nonexclusive right to perform exploration and casual-use operations. Persons other than the lessee, who wish to explore leased lands may gain access by obtaining an exploration permit from the appropriate surface management agency.

The Bureau of Land Management has primary responsibility for issuing geothermat Teases on all available federal lands. The U.S. Geological Survey and U.S. Forest Service also have responsibilities governing the issuance and administration of federal geothermal leases. The major role of these agencies in the federal leasing program is outlined below:

Bureau of Land Management

- Receiving and processing lease applications for noncompetitive areas. 
FEDERAL GEOTHERMAL REGULATORY PROCESS

Principal Pre-Lease Activites

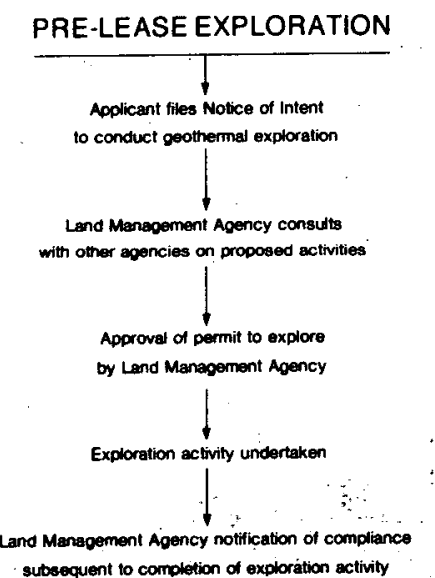

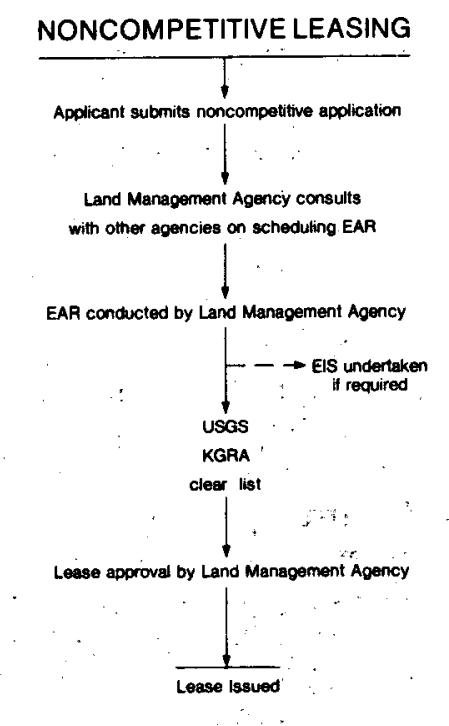

COMPETITIVE LEASING

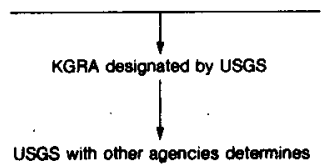

priorities for processing KGAAs

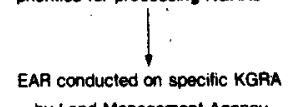

by Land Management Agency.

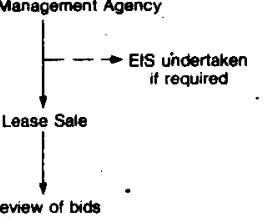

by Land Management Agency with USGS

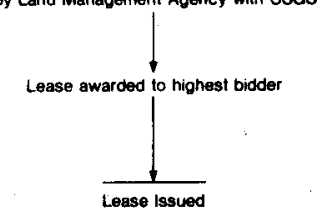

Figure 20 
- Publishing lease sale notices and receiving bids for competitive lands.

- Preparing environmental assessments on suitability of BLM lands for geothermal leasing purposes.

- Providing input to the USGS on surface consideration of post-lease environmental evaluations (USGS has primary responsibility for post-lease activities).

- Preparing lease stipulations governing special surface management programs for BLM lands.

- Supervising land uses on BLM leased land outside areas of operations.

- Awarding all leases.

- Administering lease (except those functions assigned to the USGS or Forest Service).

- Providing input on geologic setting and geothermal operations for pre-lease environmental evaluations.

- Supervising activity within the area of operation on leased lands for all phases of exploration, development and utilization.

- Preparing post-lease environmental assessments on site specific exploraton and development plans. The surface management agency, BLM or Forest Service, provides input.

- Designating "Known Geothermal Resource Areas".

- Administering terms of lease.

- Issuing Geothermal Resource Operational Orders.

- Reviewing lease stipulations formulated by the BLM or Forest Service.

- Parcelling of lease tracks.

\section{Forest Service}

- Preparing environmental assessments on suitability of national forest lands for geothermal leasing purposes.

- Providing input to USGS on surface considerations of post-lease environmental evaluations.

- Preparing lease stipulations for governing surface management for Forest Service lands. 
- Supervising land uses on leased land outside areas of operation.

- Issuing special use permits for surface occupancy.

The procedure for obtaining a federal geothermal lease depends upon the competitive interest classification of the land. Lands may be classified as "Known Geothermal Resource Areas" (KGRA) and leased on a competitive bid basis. Non-KGRA acreage is offered through a noncompetitive lease to the first qualified applicant.

\section{Competitive Leasing}

Lands designated by the USGS as KGRAs may only be leased through competitive bidding. In Oregon 431,936 acres have been so classified. These areas are shown in Figure 1. The Geothermal Steam Act defines a KGRA as:

"...an area in which the geology, nearby discoveries, competitive interest or other indicia would, in the opinion of the Secretary (of Interior), engender a belief in men who are experienced in the subject matter that the prospects for extraction of geothermal steam or associated geothermal resources are good enough to warrant expenditures of money for the purpose."

Competitive interest will also exist if at least one-half of the lands in an application are covered by another application filed during the same month.

The BLM State Office manages leasing on KGRA lands. The appropriate surface management agency, BLM or Forest Service, conducts the necessary pre-lease environmental review and determines which areas will be available for leasing. The BLM sets the lease sale date and publishes public notices. Prior to the day of the sale, each bidder must submit a statement of qualifications for leasing and a sealed bid which includes payment for at least one-fifth of the bid amount. Leases generally are awarded to the highest bidder. The federal government reserves the right to reject any and all bids.

Regulations governing KGRA status and access to federal lands are found in Title 43, Chapter II of the Code of Federal Regulations (43 CFR Part 3200).

\section{Noncompetitive Leasing}

Federal lands which have not been classified as a KGRA or excluded from leasing are available to qualified applicants on a noncompetitive basis. The procedure begins with the filing of an "Application to Lease Geothermal Resources". (Figure 21). The application requires a site description, map, proposed plan, methods for diligent operation, proof that an indiviual, corporation, or municipality is qualified to hold a lease, and other specified information. Each application must be filed with the BLM State office in a sealed envelope marked 
UNITED STATES

DEPARTMENT OF THE INTERIOR

BUREAU OF LAND MANAGEMENT
FORM APPROVED

OMB NO. 42-R1688

Serial Number

\section{APPLICATION.TO LEASE GEOTHERMAL RESOURCES}

(Sec. 4 Noncompetitive Lease)

The undersigned hereby makes application to lease all or any of the lands described herein that are available for lease pursuant and subject to the terms and provisions of the Act of December 24, 1970 (84 Stat. 1566, 30 U.S.C. Sec. 1001), or any amendments hereafter enacted, hereinafter referred to as the Act, and to all applicable regulations now or hereafter in force when not inconsistent with any express and specific provisions herein, which are made a part hereof.

1. Name (Last, First, Middle initial, print or type)

Address (include zip code)

Social Security or Taxpayer Number

2. Legal description

\begin{tabular}{l|l}
\hline State & County \\
\hline NATIONAL RESOURCE LANDS & ACQUIRED LANDS \\
\hline
\end{tabular}

Total area

Acres

Total area

Acres

3. Service charge enclosed

4. Rental enclosed

5. Compliance bond enclosed

6. Are you the sole party in interest?

7. Are you a citizen of the United States?

8 . Have you reached the age of majority?

9. Is application made for a corporation or other legal entity?

10. Has a statement of qualifications been filed?

I CERTIFY That my interests, direct or indirect, in geothermal resources leases in the above State do not exceed 20,480 acres. That the statements made herein are true, complete, and correct to the best of my knowledge and belief and are made in good faith. 
"Application for a Lease Pursuant to 43 CFR 3210 " and accompanied by a $\$ 50$ filing fee. Applications will be considered, environmental assessments conducted, and leases awarded for lands found suitable for geothermal development on the basis of priority by date of filing.

The principal pre-lease activities of the federal regulatory process are shown in Figure 22.

Salient features of the federal lease terms include:

\section{Lease Timitations}

Geothermal lease not to exceed 2,560 acres:

640 acres minimum.

20,480 acres maximum/total state holdings.

\section{Primary term}

A11 federal leases are issued for a primary term of ten years.

Lease renewal

Leases may be continued for the extent of commercial production up to an additional forty years. Leases may be renewed for a second forty-year term if commercial production continues and the acreage is not required for other use.

\section{Lease extension}

A lease that is being "diligently" drilled before the end of the primary term, will be extended for five years and for the duration of commercial production up to 35 years.

\section{Annual fees}

$\$ 1$ per acre minimum rental (exact amount set in lease).

$\$ 1$ per acre escalation annually after the fifth year until

the tenth year, or until commercial production begins.

$\$ 2$ per acre minimum during production.

Exploration expenditures during the first five years, and those in subsequent years, may be credited to the escalated portion of rent due. Rentals are paid to the BLM.

There is no rental paid after commercial production begins. All payments become royalties.

\section{Royalties}

Royalty payments are made to the USGS on a monthly basis after commercial production has begun. If the percentage royalty designated in the lease does not equal the minimum of $\$ 2$ per acre, the balance of the royalty is paid at the end of each lease year.

- 10 percent minimum and 15 percent maximum of the value of geothermal production. 
GEOTHERMAL REGULATORY PROCESS

Pre-Lease Activitles

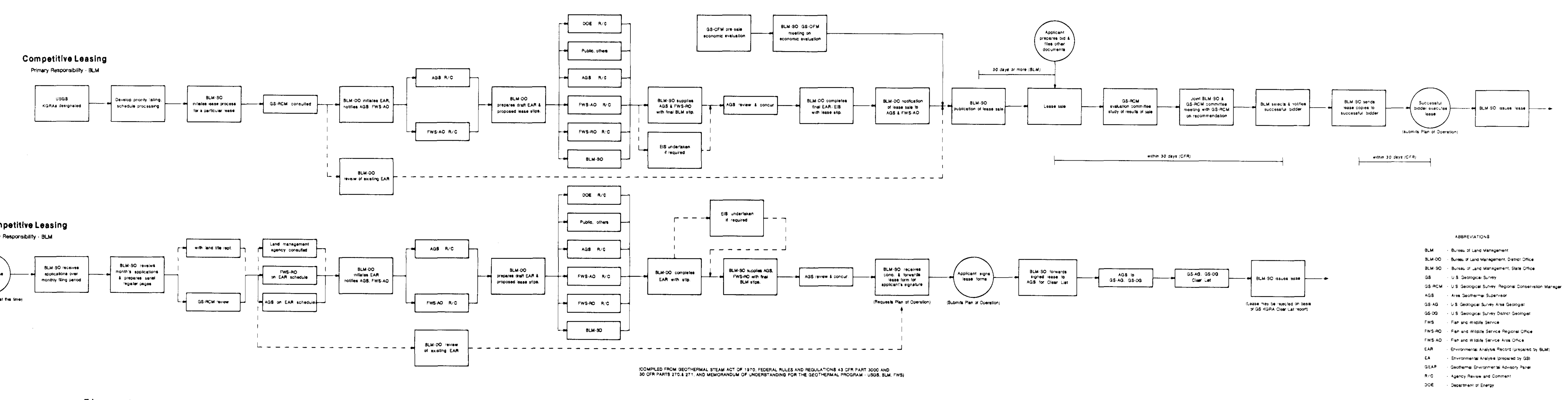


- 5 percent maximum of the value of any by-product produced.

- 22 percent maximum royalty.

Pending legislation

It is important to note that pending federal legislation may significantly alter the leasing process for public lands. For example, KGRA designations may be limited to prospects with electrical generation capabilities.

Information

For additional information, copies of applicable rules and regulations, and application forms, contact:

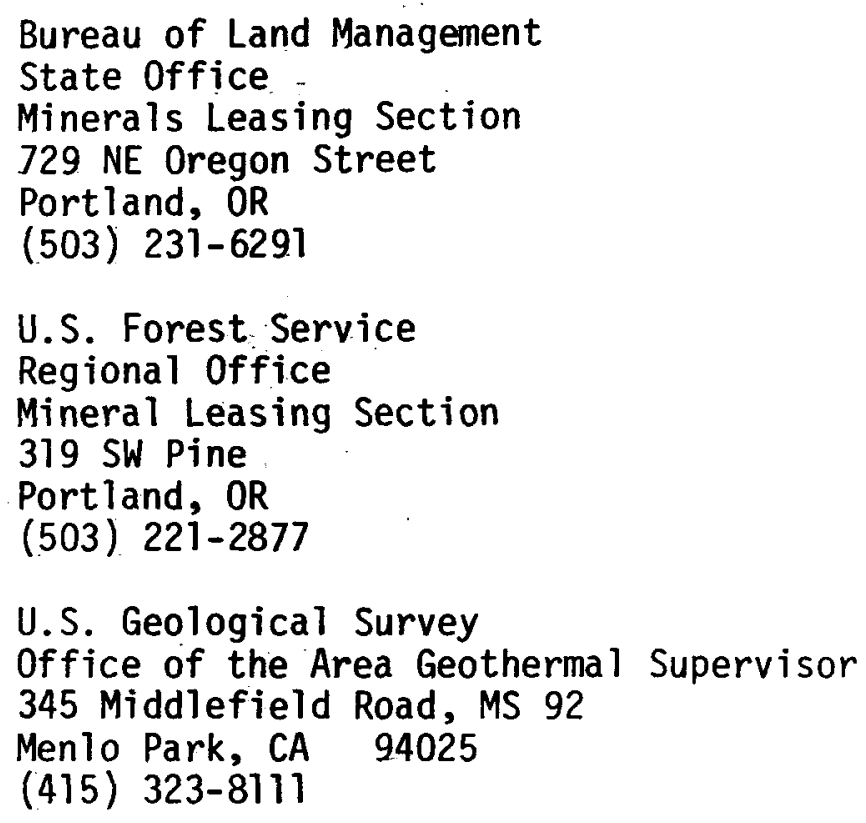

\section{EXPLORATION AND DEVELOPMENT REGULATIONS}

When clear title has been secured for a particular geothermal resource area, exploration and development should follow. Before initiating any activity the geothermal developer must obtain the necessary permits from the appropriate local, state, and federal regulators. The length of permit application review time and the number and type of permits required will vary depending upon the size of the project and the environmental sensitivity of the area. For example, a commercial geothermal greenhouse will require fewer permits and less processing time than a geothermal electric generating facility sited on federal land.

The following section describes the general types of permits that may be required. It is suggested that the developer contact the local, state, and federal agencies which may have regulatory authority for a specific project for additional details. The Oregon Department of Energy can also provide information regarding permitting requirements for a particular project. 


\section{A. Private Land}

The following types of permits may apply to a geothermal project:

- Conditional land use permits may be required from cities or counties to comply with local zoning ordinances and Land Conservation and Development Commission goals and guidelines. Contact the local planning department for information regarding applicable laws and regulations.

- Construction permits and building inspections to insure compliance with state and local codes should be coordinated through the local building and safety division.

- Drilling permits will be required from the Department of Water Resources or the Department of Geology and Mineral Industries, depending on expected well depth and temperature.

- A permit is required from the DEQ for disposal of liquid wastes such as drilling muds, equipment oils, geothermal fluids, and solid wastes.

- A Water Pollution Control Facilities permit from the DEQ may be required for injection wells.

- Other permits may be rquired from the DEQ to set limits on air emissions and fluid discharges. Contact the local or state DEQ office for specific information.

- An energy facility site certificate is required for large facilities.

\section{B. State Lands}

When a lease has been issued, exploration and development activities are subject to state, federal, and local regulations governing land use, well drilling, facility siting, and waste disposal, as outlined in the preceding section.

In addition, to develop a geothermal resource on state 1and, the Division of State Lands requires: a proposed testing program, certified copies of all tests and measurements, legal confirmation of the well's primary purpose, design alternatives considered in development planning, and measurements of the quality and quantity of all production.

\section{Federal Lands}

When BLM has issued the lease, the U.S. Geological Survey assumes primary responsibility for exploration and development operations within the federal lease area. The surface managing agency is responsible for all other areas of the lease. The USGS Conservation Division Area Geothermal Supervisor maintains regulatory control pursuant to the Geothermal Resources Operational Orders. The BLM is responsible for licensing electrical power generating facilities of $20 \mathrm{MW}$ or more. 


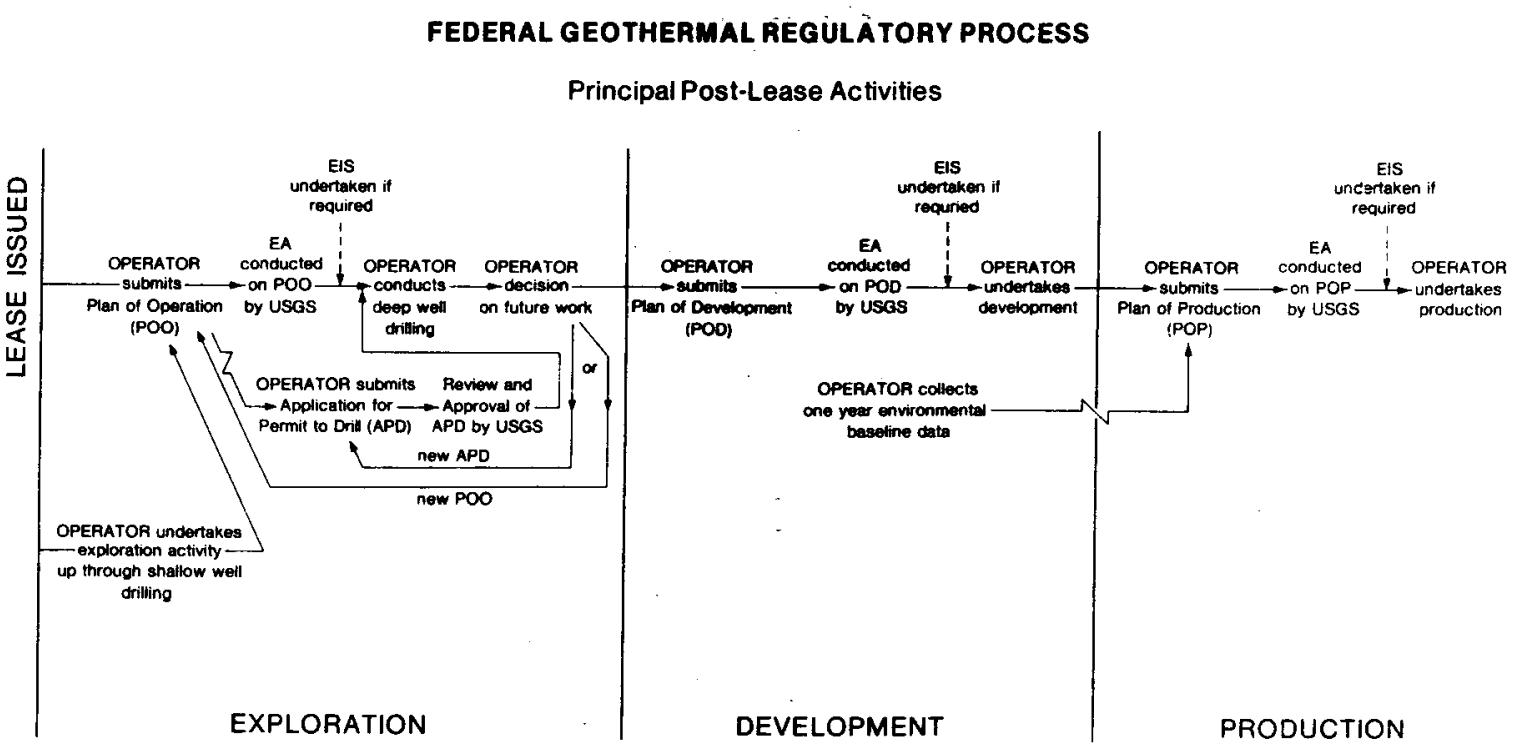

Figure 23 
Figure 23 highlights the major post-lease activities for federal lands.

Activities related to geothermal resource exploration, development, production and utilization are carried out under a Plan of Operation approved by the Area Geothermal Supervisor. Necessary permits and environmental reviews are coordinated by the Area Supervisor with the exception of permits required for emissions to the atmosphere and waste disposal which are issued by the Department of Environmental Quality. The developer must also obtain a well drilling permit from the Oregon Department of Geology and Mineral Industries. Plans of operation may be submitted sequentially by development phases or in combination, depending upon project scale and developer's data.

The principal post-lease activities of the federal regulatory process are shown in Figure 24.

1. Environmental Review Procedures

Federal agencies, generally the surface management agency and the USGS, are responsible for the preparation of environmental documents necessary to satisfy requirements of the National Environmental Policy Act and state or local environmental laws for activities conducted on federal land. State and local regulations are applicable to federal lands, but these standards are generally enforced by federal agencies. It may be necessary for the developer to perform an archaeological and native American religious site suryey and sometimes a biological survey for any threatened and endangered species.

Deep exploration drilling, development, production and utilization activities are considered major surface disturbing activities and require a site specific environmental assessment. The evaluation must discuss the affect the operation will have on the environment, recommend mitigating measures, and determine whether the operation will be a "major federal action", requiring a complete Environmental Impact assessment. Public and agency comment is afforded during the assessment period. If not considered a major federal action, the Plan of Operation is jointly approved by the Area Supervisor and the appropriate surface manager. Mitigating measures are incorporated as special conditions of approval. The developer must then obtain. the necessary drilling or construction permits from the Area Supervisor.

The environmental evaluations are prepared by the relevant federal agencies, usually at no cost to the developer. However, they may require information from the lessee, and adequate time for the preparation and review process needs to be allocated by the developer. Small scale projects may not require a full scale environmental ipact statement if analyses show that net environmental impacts are adequately offset by proposed nitigating measures. 


\section{Production}

Resource production is regulated by an approved Plan of Production from the Area Geothermal Supervisor. Before the plan is approved, the applicant must gather environmental baseline data describing the existing environmental setting for a one-year period. Requirements for baseline data may be waived by the Area Supervisor for projects that will have minimal impact. Waivers are determined on a case-by-case basis. It is important for the developer to have early consultation with the Area Supervisor to determine which requirements will apply to a specific project to facilitate planning of sufficient time and labor allocation.

GEOTHERMAL REGULATORY PROCESS (continued)

Post-Lease Activitles

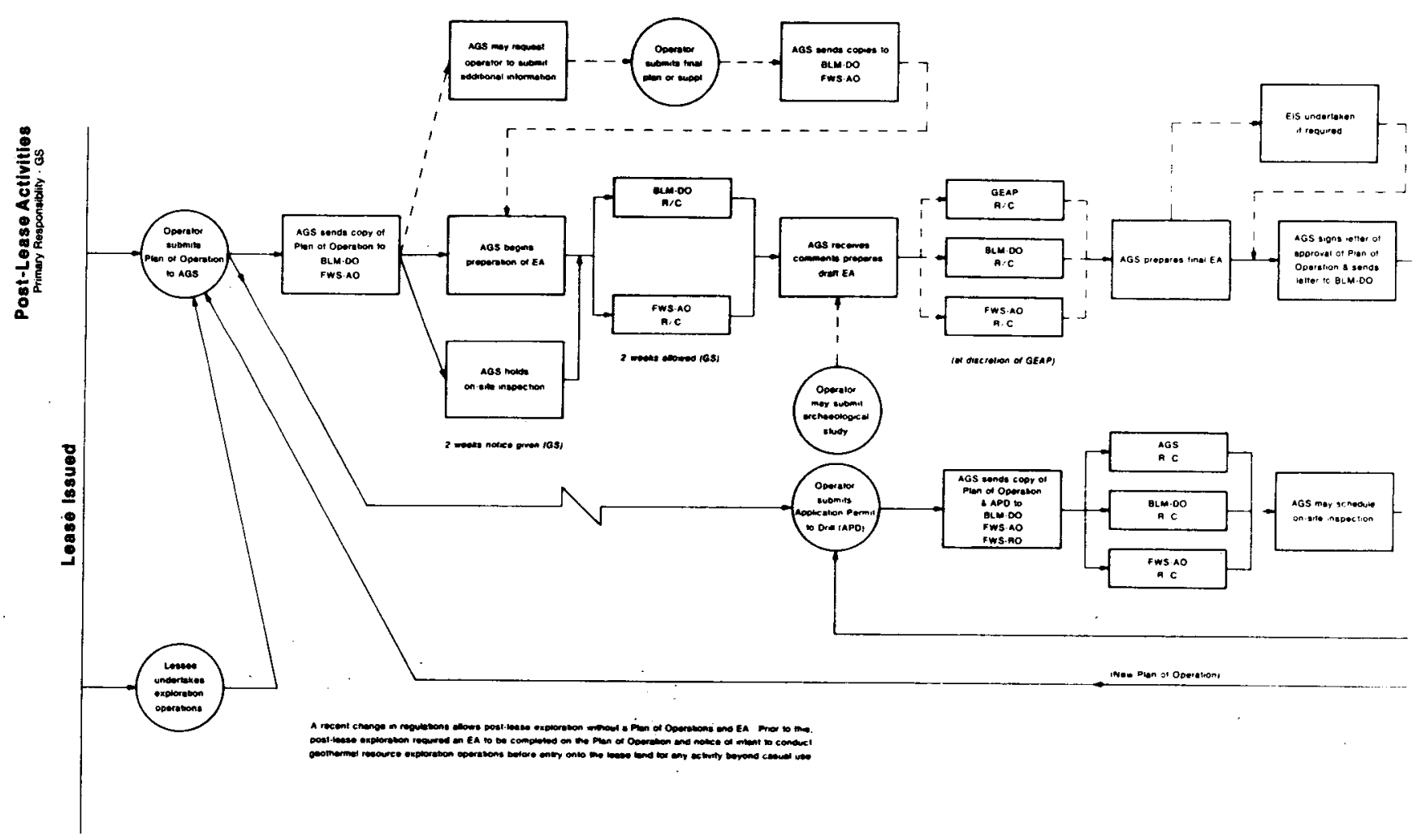

Figure 24 


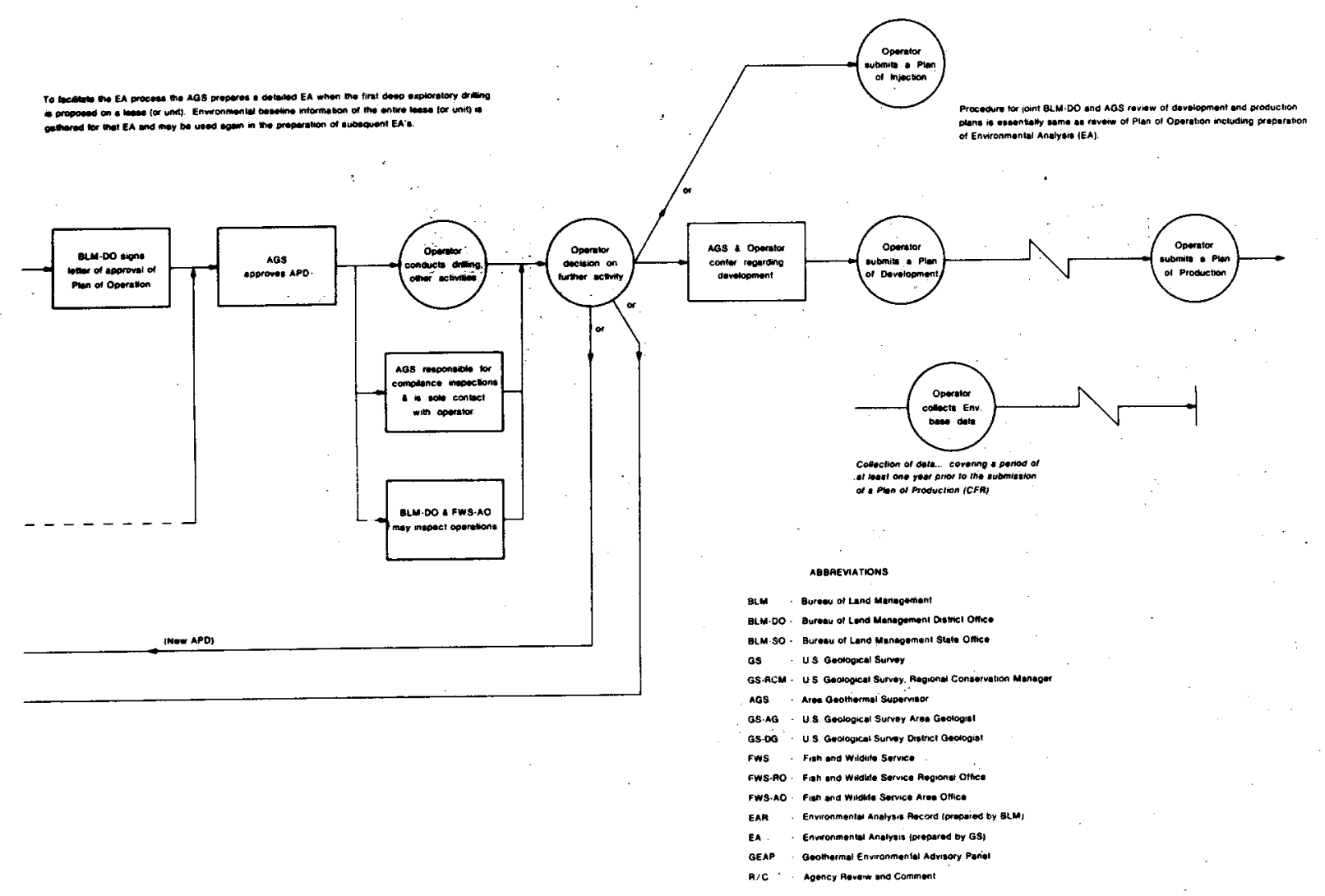


3. Facilities Construction

Small scale facilities on federal land are permitted by the Area Geothermal Supervisor, and environmental evaluations are undertaken if necessary. Larger facilities such as electric generating plants are licensed and reviewed for environmental impact by the BLM in consultation with USGS. The basic permit for facility siting covers activities only on the lease area. Transmission or distribution lines or any other off-site facility involves separate permitting procedures.

Large facilities on federal land also require an Oregon energy facility site certificate.

D. Oregon Well Permitting Procedures

The State regulates well drilling regardless of land ownership. In Oregon, regulatory responsibilities for geothermal resources are divided between two state agencies; Department of Geology and Mineral Industries (DOGAMI) and Department of Water Resources (DWR). DOGAMI regulates geothermal prospect and geothermal wells. Shallow (less than 2,000 feet) low-temperature wells are regulated by DWR, essentially in the same manner as common water wells.

If the intent is to explore for and produce geothermal fluids with temperatures of $250^{\circ} \mathrm{F}$ or greater, then the necessary permits are obtained from DOGAMI. The agency issues blanket prospecting permits which may cover numerous gradient wells 2,000 feet deep or less.

The following sections outline the general procedures for obtaining well drilling permits.

1. Well Drilling Permitting Procedure for Shallow Low-Temperature Resources (Wells less than $250^{\circ} \mathrm{F}$ BHT and/or 2,000 feet deep)

Responsible agency: Department of Water Resources

Relevant laws: Oregon Administrative Rules (OAR) Chapter 690, Division 60; ORS Chapter 537

- A permit is not needed before drilling.

- Contact a licensed well contractor.

- The contractor will file a start card with the local Watermaster describing location, proposed use and expected depth.

- $\quad A 2,000$ bond is required.

- Drilling and completion procedures must conform to OAR Chapter 690 "Rules and Regulations Prescribing General Standards for the Construction and Maintenance of Water Wells in Oregon". 
For more information contact the local Watermaster or:

Department of Water Resources

Mil1 Creek Office Park

555 13th Street NE.

Salem, OR 97310

(503) $378-3739$

2. Well Drilling Permitting Procedures for Geothermal Resources

(Prospect or geothermal wells drilled for fluids hotter than $250^{\circ} \mathrm{F}$ )

Responsible agency: Department of Geology and Mineral Industries

Relevant laws: ORS Chapter 522, OAR Chapter 632, Division 20

DOGAMI issues permits for prospect and geothermal wells as defined below. All drilling permits are conditional upon approval of local authorities.

a. Prospect wells include any wells drilled as a geophysical test well, seismic shot hole, mineral exploration drillings, core drilling or temperature gradient test wel1, less than 2,000 feet in depth, and drilled in prospecting for geothermal resources.

- File a plan of operation and hole locations (letter form).

- $\quad$ Filing fee - $\$ 100$ per permit.

- File a bond or security deposit in the sum of not less than $\$ 5,000$ or a blanket bond of $\$ 25,000$.

- DOGAMI sends notice of permit application to relevant state and local agencies who have a 15 day period in which to comment.

- A permit is granted within 30 days of receipt of application. Restrictions are added to the permit if agency comments require them. General stipulations are made a condition of every permit (Figure 25). Casing and abandonment requirements are also made conditions of each permit.

- Permitting of shallow holes is done on a blanket basis, area-by-area under one permit. As many as 100 holes may be drilled under one permit.

- Formation logs and notations of water zones encountered are required of every operator. Blowout Prevention rules require operators to monitor hole temperatures. If the temperature exceeds $125^{\circ} \mathrm{F}$, drilling: is to cease and the hole completed as an observation hole, abandoned or equipped with safety devices as prescribed by rule.

- A final statement is required of the operator describing plugging procedure. Final locations are to be submitted. 
Oregon Department of Geology and Mineral Industries

1. A plan of operation is to be submitted with the application to drill showing a plat of the drilling pad and including location of the mud sump and any road which is to be constructed. Dimensions of these items should be indicated on the plat.

2. Details of the mud system are to be submitted at the time of application giving the mud pit capacity (dimensions) and type mud to be used.

3. An emergency contingency plan is to be submitted before drilling describing:
a. field supervisor's name and how to contact,
b. blowout prevention equipment, and
c. blowout prevention drilils planned.

In the event of an emergency, a department representative should be contacted.

4. In the event of a blowout, a DOGAMI representative is to be notified as soon as possible.

5. Permission must be obtained from the State DEQ for any extraordinary off-site disposal of drilling mud or wastes or any other emergency that could affect adjoining properties.

6. Notice is to be given the State Geologist or his representative:

a. when drilling is commenced,

b. before BOP tests after running casing strings,

c. before performing work to complete or abandon a we11, and

d. before running or pulling casing strings.

7. Upon completion of drilling operations, the site is to be restored to as near original condition as is practical.

Figure 25 
- Sites are inspected for cleanup and to check for ground water leakage. The drilling bond is released if all conditions are met. Inspections are coordinated with the U.S. Geological Survey to avoid duplication.

b. Geothermal wells include any excavation made for producing geothermal resources and any geothermal injection well.

- File an application and a detailed plan of operation including: hole location, estimated drilling depth, blowout prevention equipment, waste mud and drill cuttings disposal, emergency plans, and site and road construction.

- Filing fee - $\$ 100$ per well.

- File a bond or security deposit of $\$ 10,000$ per well or a $\$ 25,000$ statewide bond.

- DOGAMI send notice of permit application to relevant state agencies and the County Board of Commissioners.

- A permit is issued within 45 days after receipt of application providing no serious concerns arise. Stipulations are made condition of every permit. Casing and cementing programs are approved and all requirements satsified before a permit is issued.

- An inspection is made early in the operation to test blowout prevention equipment, see that mud is properly being handled, and that records are being kept and drill samples collected.

- Inspections are made when fluid tests or subsequent casing strings are run.

- All subsequent cementing or casing operations are witnessed, including abandonment plugging or completion work.

- Sites are inspected for well completion and site restoration.

- All records related to the drilling must be filed with DOGAMI within 20 days after completion or abandonment. Records are held confidential for a four-year period.

- When all requirements are met, the drilling bond is released.

\section{E. Geothermal Fluid Disposal}

Oregon policy, as established by the 1979 Legislature, states that all geothermal fluids shall be injected into the same reservoir from which 
withdrawn unless it is determined by the agency responsible for well permitting that disposal by other means is in the public interest. Legislation outlining this policy specifically mentions that disposal by other means includes secondary uses of fluids produced from electrical generation and direct applications for such uses as plant cooling, and agricultural, commercial or industrial purposes.

Both the Department of Geology and Mineral Industries and the Department of Water Resources are developing regulations governing the disposal of geothermal fluids from wells under their jurisdiction. These rules will include: Standards to determine contamination, injection well construction standards, testing procedures for identifying aquifers, guidelines for conservation of the resource, criteria for evaluating reservoirs for geothermal fluid disposal, and requirements for prior approval of all geothermal fluid injection proposals. A potential geothermal developer is urged to contact the pertinent agency regarding disposal requirements.

If geothermal fluids are to be injected into an aquifer other than the one producing the fluid which is of better water quality than the geothermal fluid, a Water Pollution Control Facilities (WPCF) permit is required from $D E Q$. If pollutants are added to the fluid prior to injection, a WPCF permit will also be required. The DEQ may elect not to require a WPCF permit when injection is to the producing aquifer, or to an aquifer of like quality.

Disposal of geothermal fluid by means other than injection will always require a WPCF permit unless the fluid is discharged to surface waters. In that case, DEQ must issue a National Pollutant Discharge El imination System (NPDES) permit as required by the federal Clean water Act.

\section{F. Water Rights}

A11 water from all sources of water supply belongs, by law, to the public, and is subject to existing rights and legislative and administrative withdrawals. A right to appropriate water is obtained from the Department of Water Resources.

Water appropriations follow the doctrine of first-in-time, first-inright, so the geothermal developer should be concerned about the availability of a water right of sufficient quantity to satisfy project needs. If waters in an area have been fully appropriated, the developer may be able to obtain water rights by providing replacement supplies or purchasing rights from existing users.

In areas where waters may be appropriated, the developer files an application for a water right with the Department of Water Resources. Water may be appropriated for beneficial use by complying with the requirements of the state water code. A prudent developer should file for a water right in the initial planning stages of development.

Water rights are not required for the following applications:

- Domestic purposes of less than 15,000 gallons per day

- Irrigation of less than one-half acre

- Stock watering

- Single industrial or commercial purposes of less than 5,000 gallons per day 


\section{G. Facility Siting}

The Oregon Energy Facility Siting Council (EFSC) maintains siting jurisdiction for certain energy facilities on all lands, private, state, or federally owned. Site certificates are required for a geothermal power plant with a nominal electric generating capacity of more than 25 megawatts (ORS 469.300(10)(a)) or a pipeline transporting geothermal fluids which is six inches or greater in diameter, and five miles or longer in length (ORS $469.300(\mathrm{e})(\mathrm{A})$. The Attorney General has determined that construction of a geothermal pipeline six inches or greater in diameter which is intended or can be reasonably expected to have an ultimate length of five miles or longer cannot begin until a site certificate has been issued, even if the first stage of construction will be shorter than five miles. EFSC also maintains siting jurisdiction for high voltage transmission lines of more than ten miles in length with a capacity in excess of 230,000 volts.

The EFSC has the power to conduct investigations into all aspects of site selection, designate areas within the state as suitable or unsuitable for geothermal power plants, and to establish standards and promulgate rules which must be satisfied in order to obtain a site certificate. Suitable and unsuitable sites for geothermal development are 1 isted in "Oregon Nuclear and Thermal Energy Council Statewide Siting Task Force Report 1974".

Unlike most electrical plants, a notice of intent is not required for a geothermal electrical facility, nor is one required for a geothermal pipeline. The certification process begins by submitting a site application and the necessary fees to the EFSC (ORS 469.340, 469.350 and 469.420). If the specific site is within an area designated as unsuitable, the application is not accepted. However, the suitability classification may be amended by the Council's own motion or petition.

Specific standards for geothermal site certificates have not been established. General standards, which apply to all energy facilities, require the following mandatory findings: need for the proposed facilitiy based on energy demand and economic prudence, protection of public health and safety, environmental protection, beneficial use of wastes and byproducts, conformance with statewide planning goals and comprehensive land-use plans, protection of historical and archaeological sites, no infringement on existing water rights, necessary expertise to operate, construct and retire the facility, reasonable assurance of obtaining the necessary funds, and identification of foreseeable socioeconomic impacts in the vicinity of the proposed facility (OAR 345-74-025). Specific standards for the siting of geothermal power plants and pipelines are likely to be developed in the next few years.

When a site application has been filed, EFSC distributes copies to twelve state agencies and any local governments affected by the application. This coordination with other agencies makes siting a one-stop process for the applicant to satisfy Oregon requirements. The agencies must make provisions that they would normally make in their own permitting process in the site certification process. Any stipulations must be included as site certificate conditions, and once a site certificate is granted, the agency permits or licenses must be granted as a matter of 
course. The applicant, however, does need to apply directly for the necessary permits and licenses. The permitting agency retains the authority to enforce the requirements of the 1 icense.

The EFSC investigates each site application to determine satisfaction of mandatory finding and may commission independent studies of any proposed aspect of the facility. Costs of studies are paid from the filing fee; however, if costs exceed the fee, all additional expenses are borne by the applicant. Any unused portion of the filing fee is returned to the applicant.

Public hearings in the affected area and elsewhere are required as deemed necessary by the EFSC. The EFSC then either approves or rejects the application. The EFSC is required to make a decision with in nine months after filing of an application for a geothermal power plant and within twelve months for a pipeline. Rejection or approval of an application is subject to direct judicial review by the Supreme Court.

A site certificate authorizes the applicant to construct and operate a geothermal facility under conditions set forth in the certificate. The signed certificate binds the state and all affected political subdivisions to the approval of the site for construction and operation of the facility. A11 necessary permits and 1 icenses must be issued, subject only to the conditions of the site certificate. The EFSC can only initiate changes in a site certificate based upon a clear indication of danger to the public health and safety.

The holder of a site certificate is required to pay a fee each year during construction and operation of the facility. EFSC maintains continuing authority over the site.

\section{DISTRIBUTION AND USE}

The final phase of geothermal development is to provide for use of the resource. The extent of regulations governing transport and use of geothermal energy are proportional to the scale of the end-use. An investor-owned utility selling electricity must comply with the most comprehensive set of regulations while a one-well/one-home heating system represents the low end of the regulatory continuum.

Homeowners, who propose to use a geothermal well situated on their own property for space heating, are subject to local regulations governing land use and code enforcement. In some areas, such as Klamath Fal Is local entities are developing geothermal management ordinances, whereby new wells will have to comply with city regulations. Aevelopers should contact city or county governments to determine applicability of zoning ordinances and identify necessary permits such as construction and plumbing permits.

Most other types of development include a distribution system that will require obtaining the right to cross many parcels of property. Transportation corridor selection will depend on the user's ability to secure rights-of-way. Outright purchase of property is one option. Systems intended for public use, such as a municipal district heating system, may be able to exercise the power of eminent domain to purchase private land for public benefit. Both public and private users can gain the 
limited right to access by obtaining an easement from the property owner. Easements along existing rights-of-way, such as highways and railroads, are obtained from the appropriate government agency or private owner.

Geothermal developments on all lands involving large pipelines or high voltage transmission lines require site certificates from the Oregon Energy Facility Siting Council before construction. EFSC authority over the site continues during operation. Federal authorities are responsible for regulating electric transmission lines.

Geothermal resources developed on federal leases require permits or licenses to transmit power or transport fluids. Authorizations are issued by the BLM under provisions of the Federal Land Policy and Management Act. Land use policies of the surface management agency and environmental assessments are considered in the permitting process.

All types of land uses must conform to local regulations, including zoning ordinances, comprehensive land use plans and building, plumbing and electrical codes.

When a system is in operation, financial considerations also come into effect. If development has taken place on leased land, royalty payments will be initiated. Utility service provided for electric or direct heat use will be subject to regulations by the Public Utility Commission. The Department of Environmental Quality may also impose regulations to govern a facility's operation to protect the public interest.

\section{INFORMATION, ASSISTANCE AND INCENTIVES}

\section{A. Information Sources}

Information regarding geothermal development and use is available from a variety of public and private sources. Federal and state agencies responsible for alternate energy planning, development and regulation can provide information concerning technical, economic, institutional aspects, and financial support for geothermal development and use. Local sources of information include universities, planning departments, area economic development groups; the Energy Extension Service, and local energy centers. Private consultants can also provide valuable assistance ranging from resource identification to project engineering. It is suggested that initial contact be made with the oregon Department of Energy and U.S. Department of Energy to determine the most appropriate sources of information. Several of the key contacts are listed below:

\section{U.S. Department of Energy (U.S. DOE)}

U.S. DOE administers programs which deal with all aspects of geothermal energy from research and development to construction of demonstration projects. National programs are managed from U.S. DOE headquarters in Washington, B.C. The DOE regional representative's office in Seattle administers many of these programs in the Pacific Northwest. 


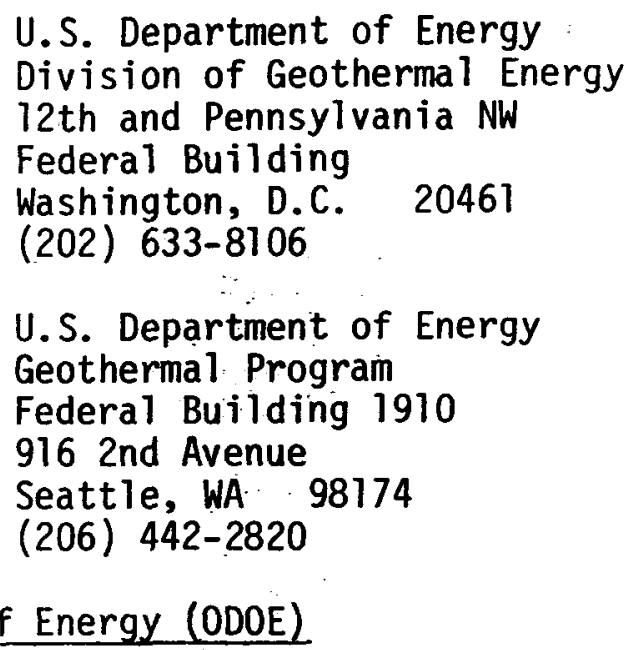

Oregon Department of Energy (ODOE)

ODOE administers a state program to promote commercialization of geothermal resources. ODOE can provide information and assistance concerning resource areas, development status, incentives and funding sources, technical data on resource applications, and the legal and institutional framework which guides development.

$$
\begin{aligned}
& \text { Oregon Department of Energy } \\
& \text { Geothermal Program } \\
& 102 \text { Labor and Industries Building } \\
& \text { Salem, OR } 97310 \text {. } \\
& \text { (503) } 378-4040 \text { or Tol1 Free 1-800-452-7813 }
\end{aligned}
$$

\section{Oregon Institute of Technology - Geo-Heat Utilization Center}

The Geo-Heat Utilizaton Center manages a variety of geothermal programs which emphasize direct heat applications. These efforts include regional planning, technical assistance, market studies and outreach activities. The Center publishes a quarterly bullet in which highlights current activities and technologies in the geothermal direct use field. Information is available concerning planning, permitting, construction, economics and resource evaluation, and current development status for direct use applications at the state, national, and international level.

$$
\begin{aligned}
& \text { Geo-Heat Utilization Center } \\
& \text { Oregon Institute of Technology } \\
& \text { Klamath Falls, OR } .97601 \\
& \text { (503) 882-6321 Ext. } 267
\end{aligned}
$$

Oregon Department of Geology and Mineral Industries (DOGAMI)

The Department participates in a geothermal program with the U.S. DOE and U.S. Geological Survey to assess geothermal resource areas in Oregon. DOGAMI can provide valuable information concerning resource characteristics and drilling permit procedures. DOGAMI publishes an annual review of exploration activities, generally in a spring edition of Oregon Geology.

Oregon Department of Geology

\& Mineral Industries

1069 State Office Building

Portland, OR 97201

(503) 229-5580 
The GRC is a non-profit professional organization dedicated to information dissemination and support of geothermal education programs. GRC offers seminars and technical training sessions, and publishes special reports, a monthiy bulletin and a directory. GRC can provide references and contacts for all aspects of geothermal development and use.

Geothermal Resources Council

P.0. Box 98

Davis, CA 95616

(9.16) $758-2360$

\section{B. Technical Assistance}

As a part of the U.S. Department of Energy's geothermal program, technical assistance is available, at no cost, to private, public, or corporate entities interested in using geothermal resources. The program is intended to provide assistance to persons with little or no experience in the geothermal field in order to promote rapid development of geothermal energy. The amount of assistance is limited in order to protect the interests of private organizations involved in geothermal activities. Assistance is provided, as requested, on a first come, first served basis.

The Geo-Heat Utilization Center can provide assistance in the form of limited resource evaluation, engineering and economic feasibility studies, materials selection, corrosion problems, conceptual design, institutional factors, and consultation with private engineers and consulting geologists.

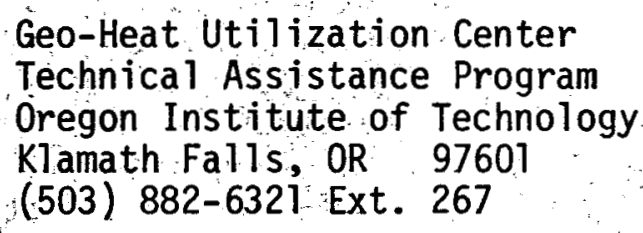

In a similar manner, the University of Utah Research Institute can provide service for geologic, geophysical, and other resource evaluation assistance.

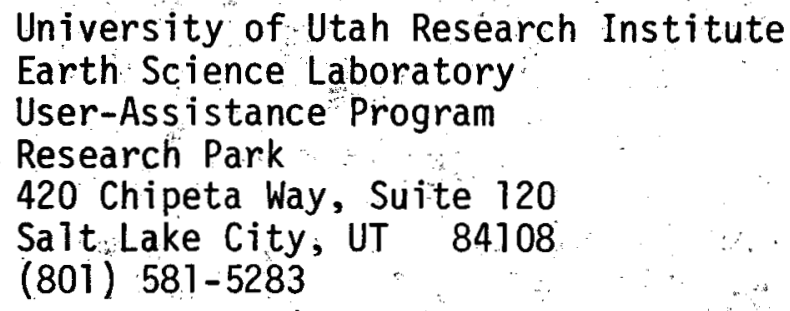

\section{Funding Opportunities}

The most direct method to fund geothermal projects is to secure private financing through lending institutions, investment companies and individual investors. Since most financial organizations have had little experience in dealing with alternate energy development projects, it is essential: that the developer be knowledgeable of all aspects of resource utilization and present a comprehensive management and development plan. 
Government funding opportunities are limited and competition for available funds is keen. Several of the sources listed below are earmarked specifically for geothermal projects, others are standard public works and economic development programs available to state and local governments and private entities which may be available for moderate-to-large scale geothermal development projects.

\section{Federal Programs}

\section{U.S. Department of Energy}

- Geothermal Loan Guarantee Program - The program offers loan guarantees for up to 75: percent of project costs to encourage public and private sectors to accelerate geothermal resource development by minimizing the lender's financial risks.

\section{U.S. Department of Energy}

Geothermal Loan Guarantee Program

San Francisco Operations Office

1333 Broadway

Oakland, CA 97612

(415) 273-7157

- Program Research and Development Announcement (PRDA) - The PRDA program offers funding for engineering and economic feasibility studies of direct applications for specific sites. Proposals may be submitted in response to specific announcements, generally issued annually, by all sectors except federal agencies and national laboratories. Specific requirements are stipulated for each PRDA which may limit the scope of study to a particular area such as industrial processing or district heating.

\section{U.S. Department of Energy}

San Francisco Operations office

Geothermal Division

1333 Broadway

Oakland, CA 94612

(415) 223-7943

- $\quad$ Program Opportunity Notice (PON) - Funding is provided under the P.ON program to accelerate the near-term commercialization of direct applications by cost-sharing the development and construction of demonstration projects. Private and public interests can qualify. PON announcements are usually released annually and may be directed to a specific area such as industrial development.

Contact the Oakland office of the U.S. DOE.

- User-Coupled Confirmation Drililing Program - The confirmation drilling program will cost-share expenses for exploration to site drill holes, drilling, flow testing, reservoir engineering, and injection well drilling for direct heat applications. The federal percentage of the cost-share will be determined by a negotiated formula based upon the degree of success of the 
confirmation project. Private individuals, businesses, state and local governments can offer proposals under this program.

This new program will be initiated by a Solicitation for Cooperative Agreement (SCA) in May 1980. Proposals are to be submitted within a 60-day period. Additional SCAs will be issued in the near future, but exact schedules have not been set.

\author{
U.S. Department of Energy \\ Geothermal Division \\ User-Coupled Confirmation Drilling Program \\ 550 2nd Street \\ Idaho Falls, Idaho 83401 \\ (208) $526-1669$
}

- Appropriate Technology Grant Program - The AT Grant Program offers grants to support smal7 scale technologies for energy conservation and renewable resource development. Grants are available to individuals, nonprofit organizations, small businesses, state and local governments, and Indian nations.

Appropriate Technology Small Grants Program U.S. Department of Energy.

Federal Building 1910

916 2nd Avenue

Seattle, WA 98174

(206) 442-2820

$\mathrm{OR}$

Oregon Department of Energy

102 Labor \& Industries Building

Sa Jem, OR 97370

(503) 378-4040 or To17 Free 1-800-452-7813

- Institutional Buildings Grants Program - The program provides funding on a cost-shared basis for schools, hospitals, local governments and public care facilities to conduct technical assistance studies for energy conservation and alternative energy development. Schools and hospitals are eligible to receive funds for implementation of capital improvement projects recommended by the technical studies.

Contact the Seattle office of U.S. DOE or the Oregon Department of Energy.

In addition to these U.S. DOE programs, unsolicited proposals may be accepted, and specific solicitations to fill immediate program needs may be issued at various times. Contact the Seattle office of U.S. DOE or

U.S. Department of Energy

Division of Geothermal Energy

12 th and Pennsylvania NW

Federal Building

Washington; D.C.

20461

(202) 633-8106 


\title{
Farmers Home Administration
}

- Businessess and Industrial Development Loans and Grants - The program provides assistance to organizations or individuals in rural areas to improve, develop or finance business, industry and employment in order to improve the economic and environmental climate through joan guarantees and project grants.

- Community Facility Loans - Insured loans are available to public entities and nonprofit organizations in rural areas with populations less than 10,000 to construct or expand community facilities which provide essential services.

Farmers Home Administration

1220 SW 3rd

Portland, $O R$

(503) $221-2731$

\section{Economic Development Administration}

- Public Works and Development Facilities - Assistance is provided to public and nonprofit groups through grants and direct loans to promote growth and expansion of private sector industry through public works and development facilities grants in EDA-designed areas to alleviate unemployment.

- Business Development Loans - The program offers direct loans and guarantees not available from private sources to assist businesses in preserving or expanding employment opportunities, or expanding/constructing new facilities.

\author{
Economic Development Administration \\ 1220 SW 3rd \\ Portland, $O R$ \\ (503) $221-3078$
}

Department of Housing and Urban Development

- Community Development Block Grants - Grants are available to large and small cities to help alleviate physical and economic distress through stimulation of private investment and community revitalization in areas with population outmigration or a declining tax base. Funds may be applied to projects such as housing and neighborhood conservation, local development corporations, and financing commercial or industrial building construction. Small cities with populations of less than 50,000 that are not in urban counties can apply funds for construction and improvement of public works facilities.

- Urban Development Action Grants - Cities and urban counties in HUD-designated areas can qualify for project grants to enhance economic revitalization. Project grants aim to stimulate new 
development and investment in distressed areas through public and private sector financial partnerships.

Department of Housing and Urban Development 530 SW 6 th

Portiand, $O R$

(503) 221-2558

\section{Regiona1 Programs}

The Pacific Northwest Regional Commission has provided funds for geothermal energy studies in the past. Coinformation on current programs.

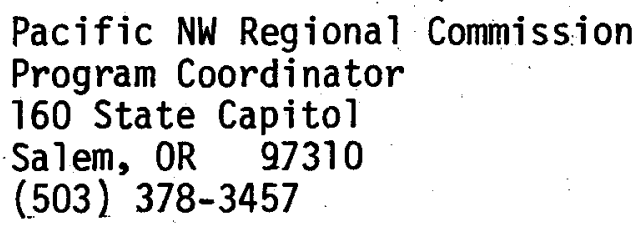

\section{3.: State Programs}

The Oregon Department of Energy has administered a small grants program for community energy projects, and contracts for district heating feasibility studies. Contact the ODOE for information regarding current programs.

Oregon Department of Energy

102 Labor \& Industries Building

Salem, OR 97310

(503) $378-4040$ or Tol1 Free 1-800-452-7813

- Small Scale Local Energy Projects - Subject to voter approval at the May 1980 election, individuals, small businesses, nonprofit organizations, and municipalities will be eligible to apply to the Oregon Department of Energy for small scale energy loans for projects that are renewable resources to meet community or regional needs.

\section{Incentives}

\section{Federal}

Residential income tax credits are available for geothermal energy expenditures. The credit is 40 percent of the cost of geothermal equipment up to $\$ 10,000$ for a maximum credit of $\$ 4,000$.

Businesses may qualify for a 15 percent investment energy tax credit for geothermal equipment, in addition to the regular 10 percent investment credit.

Private geothermal developments may be able to deduct intangible drilling costs and make allowances for percentage depreciation:

Contact the local Internal Revenue Service for additional information. 


\section{State}

Residential income tax credits are available to homeowners, renters, landlords, contract purchasers and builders for the cost of geothermal systems certified prior to installation by ODOE. The credit equals 25 percent of the actual system costs up to $\$ 1,000$ per dwelling.

Property equipped with a geothermal system is exempt from ad valorem taxation.

Residential taxpayers can claim a 25 percent income tax credit, up to a maximum of $\$ 1,000$, for the cost of connection to a geothermal district heating system.

Business and industry income tax credits for the installation of equipment to use geothermal energy resources are available to facilities certified by $000 \mathrm{E}$ prior to construction or improvements. The credit is equal to 35 percent of the cost of the equipment and is claimed over a five-year period.

Information regarding these programs may be obtained from the Oregon Department of Energy and the State Department of Revenue.

In addition to these financial incentives, Oregon has provided the nation's first institutional impetus for municipal heating districts by enactment of model legislation allowing many communities to beneficially manage local geothermal resources. 
Allen, E.M., 1980, Legal and Institutional-Factors, unpublished report to the Oregon Geothermal Task Force.

Anderson; D.N., and Lund, J.W., eds., 1979, Direct Utilization of Geothermal Energy - A Technical Handbook, Geothermal Resources Council Special Report No. 7, Davis, Cal ifornia.

Beeland, G.V., Sebran, D.J. and Whiteright, D.K., 1978, Geotherma 1 Development on Federal Lands - the Impediments and Potential Solutions: U.S. Department of Energy TID-28270.

Geothermal Resources Counci1, 1979, Geothermal Resources and the Institutional Maze: proceedings, Management Survey Course No. 1, Davis, California.

Hammer, G.D., Esposito, L., and Montgomery, M. , 1979, Idaho Geothermal Handbook: Idaho Office of Energy, Boise, Idaho.

Justus, D.L., 1979, Geothermal Resources in Oregon: Site Data Base and Development Status: Geo-Heat Utilization Center, Oregon Institute of Technology, Klamath Falls, Oregon.

Lyons, T., 1977, Geotherma 7 resources leasing program - administrative requirements for development of geothermal resources: Geotherma 1 Energy Magazine, November 1977.

Petroleum Information Corporation, 1979, The Geothermal Resource: Denver, Colorado.

Sacarto, D.M., 1976, State Policies for Geothermal Development: National Conference of State Legislatures, Denver, Colorado. 


\section{SELECTED REFERENCES}

Baldwin, E.M., 1964, Geology of Oregon: University of Oregon, Eugene.

Berg, J.W., Jr., and Thiruvathukal, J.W., 1967, Complete Bouger Gravity Anomaly Map of Oregon: Oregon Department of Geology and Mineral Industries Map GMS 4-b.

Blackwe11, D.D., Hull, D.A., Bowen, R.G., and Steele, J.L., 1978, Heat Flow of Oregon: Oregon Department of Geology and Mineral Industries Special Paper 4.

Bowen, R.G. and Blackwell, D.D., 1975, The Cow Hollow Geothermal Anomaly, Malheur County, Oregon: OreBin, V. 37, N. 7.

Bowen, R.G., Blackwe11, D.D., 1975, Geothermal Studies and Exploration in Oregon: Oregon Department of Geology and Mineral Industries Open File Report.

Bowen, R.G., Blackwe11, D.D., and Hull, D.A., 1977, Geothermal Exploration Studies in Oregon: Oregon Department of Geology and Mineral Industries Miscellaneous Paper 19.

Bowen, R.G., Blackwe11, D.D. and Hull D.A., 1975, Geothermal Studies and Exploration Studies in Oregon: Oregon Department of Geology and Mineral Industries Open File Report 0-75-7.

Bowen, R.G., Peterson, N.V., and Riccio, J.F., 1978, Low-to-Intermediate Temperature Thermal Springs and Wells in Oregon: Oregon Department of Geology and Mineral Industries, GMS-10.

Clayton, C.M., 1976, Geology. of the Breitenbush Hot Springs Area, Cascade Range, Oregon: Portland State University Master's Thesis.

Corcoran, R.E., Doak, R.A., Porter, P.W., Pritchett, F.I. and Privrasky, N.C., 1962, Geology of the Mitchel1 Butte Quadrangle. Oregon: Oregon Department of Geology and Mineral Industries GMS-2.

Couch, R., French, W., Gemperle, M. and Johnson, A., 1975, Geophysical Measurements in the Vale, Oregon Geotherma 7 Resource Area: OreBin V. 37, N. 8 .

Couch, R.W., 1977, Analysis of Geophysical Data Pertaining to the Vale KGRA, Final Report to the Geothermal Research Program: U.S. Geological Survey Grant 15-08-001-6-222.

Culver, G.G.., Lund, J.W. and Svanievik, L.S., 1974, Klamath Falls Hot Water Well Study: Lawrence Livermore Laboratory, University of California, UCRL-13614.

Dellechaie, F., 1978, A Geological and Hydro-Geochemical Study of the LaGrande Area, Union County, Oregon: Transactions, Geothermal Resources Council, V. 2 . 
Donath, F.A., 1962, Analys is of Bas in-Range Structure, South-Central Oregon: Geologic Society of America Bulletin, V. 73, N. 1.

Griscom, A. and Conrad, A., 1975, Principal Facts and Preliminary Interpretation for Gravity Profiles and Magnetometer Profiles in the Alvord Valley, Oregon: U.S. Geological Survey Open File Report 75-293.

Hammond, Paul E., 1976, Preliminary Report on the Reconnaissance Geology of the Upper Clackamas and North Santiam Rivers Area, Cascade Range, Oregon: Draft Report to Oregon Department of Geology and Mineral Industries .

Hampton, E.R. and Brown, S.G., 1964, Geology and Groundwater Resources of the Upper Grande Ronde River Basin, Union County, Oregon: U.S. Geological Survey Water Supply Paper 1497.

Hampton, E.R. and Brown, S.G., 1964, Geology and Groundwater Resources of the Upper Grande Ronde River Basin, Union County, Oregon: U.S. Geological Survey Water Supply Paper 1597.

Higgins, Michael W., and Waters, Aaron, C., 1967, Newberry Caldera, Oregon: A Preliminary Report: OreBin, V. 29, N. 3.

Huggins, Rich, ed., 1978, Northeast Oregon Geothermal Potential: Eastern Oregon Community Development Council, LaGrande, Oregon.

Hu11, D.A. 1976, Electrical Resistivity Survey and Evaluation of the Glass Butte Geothermal Anomaly: Oregon Department of Geology and Mineral Industries Open File Report 0-76-11.

Hu11, D.A., Bowen, R.G., Blackwe11, D.D., Peterson, N.W., 1975, Geotherma 1 Gradient Data Brothers Fault Zone, Oregon: Oregon Department of Geology and Mineral Industries Open File Report 0-76-2.

Hu11, D.A., Blackwe11, D.D., Bowen, R.G. and Peterson, N.V., 1977, Heat Flow Study of the Brothers Fault Zone, Oregon: Oregon Department of Geology and Mineral Industries Open File Report 0-77-3.

Hul1, D.A., Blackwe11, D.D., Bowen, R.G., Peterson, N.V., and Black, G.L., 1977, Geothermal Gradient Data: Oregon Department of Geology and Mineral Industries, Open File Report 0-77-2.

Hul1, D.A., Blackwel1, D.D., and Black, G.L., 1978, Geothermal Gradient Data: Oregon Department of Geology and Mineral Industries, Open File Report 0-78-4.

Justus, D.L. 1979, Geotherma 1 Resources in Oregon: Site Data Base and Development Status, Oregon Institute of Technology.

Larson, K. and Couch, R., 1975, Preliminary Gravity Maps of the Vale Area, Malheur County, Oregon: :OreBin, V. 37, N. 8. 
Lawrence, R.D., 1976, Strike-Slip Faulting Terminates the Basin and Range Province in Oregon: Geological Society of America Bulletin, V. 87.

Leonard, A.R. and Harris, A.B., 1974, Ground Water in Selected Areas in the K1amath Basin, Oregon: Oregon State Engineer Ground Water Report 21.

Lienau, Paul, Principal Investigator, 1978, Geothermal Energy for AgriBusiness for Klamath and Western Snake River Basins, Oregon: Geo-Heat Utilization Center, Oregon Institute of Technology.

Long, C.L. and Gregory, D.I., 1975, Audio-magnetotelluric Apparent Resistivity Maps for Parts of Harney County, Oregon: U.S. Geological Survey Open File Report 75-297.

Long, C.L., Hoover, D.G. and Bramsoe, E., 1976, Audio-Magnetotelluric Apparent Resistivity Maps, Weiser, Idaho - Vale, Oregon: U.S. Geological Survey Open File Report 75-103.

Lund, John W., 1978, Geothermal Hydrology and Geochemistry of Klamath Falls, Oregon Urban Area: U.S. Geological Survey Grant No. 14-08$0001-G-291$.

MacLeod, N.S., Walker, G.W. and McKee, E.H., 1975, Geothermal Significance of Eastward Increase in Age of Upper Cenozoic Rhyolitic Domes in Southeastern Oregon: U.S. Geological Survey Open File Report.

MacLoed, N.S., Walker, G.W. and McKee, E.H., 1975, Geothermal Significance of Eastward Increase in Age of Upper Cenozoic Rhyolitic Domes in Southeastern Oregon: U.S. Geological Survey Open File Report 75-348.

Mariner, R.H., Rapp, J.B., Willey, L.M., and Presser, T.S., 1974, The Chemical Composition and Estimated Minimum Thermal Reservoir Temperatures of Selected Hot Springs in Oregon: U.S. Geological Survey Open File Report.

Mariner, R.H., Rapp, J.B., Willey, L.M. and Presser, T.S., 1975, The Minor and Trace Elements Gas, and Isotope Compositions of the Principal Hot Springs of Nevada and Oregon: U.S. Geological Survey, Open File Report.

Meyer, Jack, and Hook, John, 1978, Geothermal Study of the Lakeview, Lake County, Oregon: Northwest Geothermal Corporation Report.

Muffler, J.P., ec., 1978, Assessment of Geothermal Resources of the United States. - 1978: U.S. Geological Survey Circular 790.

Newcomb, R.C. and Hart, D.H., 1958, Preliminary Report on the Groundwater Resource of the Klamath River Basin, Oregon: U.S. Geological Survey, Open File Report.

Newton, V.C., Jr., and Corcoran, R.E.: 1963, Petroleum Geology of the Western Snake River Plain Basin: Oregon Department of Geology and Mineral Industries 0il and Gas Investigation 1.

Oregon Nuclear and Thermal Energy Council, 1974, State-wide Siting Task Force Report: Oregon Department of Energy. 
Peck, P.L., et. al., 1964, Geology of the Central and Northern Parts of the Western Cascade Range in Oregon: U.S. Geological Survey Professional Paper 449.

Peterson, N.V., and Groh, E.A., 1965, Newberry Volcano Area Field Trip, Lunar Geological Field Conference Guidebook: Oregon Department of Geology and Mineral Industries Bulletin 57.

Peterson, N.V., and Groh, E.A., 1969, The Ages of Some Holocene Volcanic Eruptions in the Newberry Volcano Area, Oregon: Ore Bin, V. 31, N. 4.

Peterson, N.V., Groh, E.A., Taylor, E.M., Stensland, E.E., 1976, Geology and Mineral Resources of Deschutes County, Oregon: Oregon Department of Geology and Mineral Industries Bulletin 89.

Peterson, N.V. and McIntyre, J.B., 1970, The Reconnaissance Geology and Mineral Resources of Eastern Klamath County and Western Lake County, Oregon: Oregon Department of Geology and Mineral Industries Bulletin 66:

Phillips, K.M., 19.35, A Chemical Study of Fumaroles on Mount Hood: Mazama, V. 18.

Phillips, K.M. and Van Denburgh, A.S., 1971, Hydrology and Geochemistry of Abert, Summer and Goose Lakes and other Closed Basin Lakes in Southcentral Oregon: U.S. Gelolgical Survey Professional Paper 502-B.

Piper, A.M., Robinson, T.W., and Park, C.F., Jr., 1939, Geology and Groundwater Resources of the Harney Basin, Oregon: U.S. Geological Survey Water Supply Paper 841 .

Plouff, D. and Conradi, A., Jr., 1975, Gravity and Magnetic Profiles and Maps, Crump Geyser Area, Oregon: U.S. Geological Survey Open File Report 75-346.

Reistad, G.M., Schmisseur, W.E., Shay, R.J., and Fitch, J.B., 1978, An Evaluation of Uses for Low to Intermediate. Temperature Geothermal Fluids in the Klamath Basin, Oregon: Oregon State University Engineering Experiment Station, Bulletin N. 55.

Riccio, J.F., 1979., Preliminary Geothermal Resource Map of Oregon: Oregon Department of Geology and Mineral Industries GMS-11.

Samme1, W.A., 1976, Hydrologic Reconnaissance of the Geothermal Area near Klamath Fa11s, Oregon: U.S. Geological Survey Water Resources Investigation Open File Report WRI 76-127.

Sass, J.H., Galanis, S.P., Munroe, R.J. and Urban, T.C., 1976, Heàt Flow Data from Southeastern Oregon: U.S. Geological Survey Open File Report 76-217.

Sass, J.H. and Sammel, E.A, , 1976, Heat Flow Data and Their-Relation to Observed Geothermal. Phenomena near Klamath Falls; Oregon: Journal of Geophysical Research, V. 81, N. 26.

Stewart, J.H., Walker, George W., and Kleinhampl, F.J., 1975, Oregon-Nevada Lineament: Geology, V. 3, N. 5 . 
U.S. Geological Survey, Geothermal Resources File (Geotherm) Revision 8, Computer Data File.

Walker, G.W., 1963, Reconnaissance Geological Map of the Eastern Half of the Klamath Falls (AMS) Quadrangle, Lane and Klamath Counties, Oregon: U.S. Geological Survey Mineral Investigations Field Studies Map MF-260.

Walker, G.W., 1973, Reconnaissance Geologic Map of the Pendleton Quadrangle, Oregon and Washington: U.S. Geological Survey Miscellaneous Geologic Investigation Map 1-727.

Walker, G.W., and Repenning, C.A., 1965, Reconnaissance Geologic Map of the Adel Quadrangle, Lake, Harney, and Malheur Counties, Oregon: U.S. Geological Survey Miscellaneous Geologic Investigation Map 1-446.

Walker, George W., 1969, Geology of the High Lava Plains Province, Mineral and Water Resources of Oregon: Oregon Department of Geology and Mineral Industries Bulletin 64.

Walker, George W., 1974, Some Implications of Late Cenozoic Volcanism to Geothermal Potential in the High Lava Plains of South-central Oregon: Ore Bin, V. 36, N. 7.

Waring, Gerald W., 1965, Thermal Springs of the United States and Other Countries of the World - A Summary: U.S. Geological Survey Professional Paper 492.

White, Craig, 1980, Geology and Geochemistry of Mount Hood Volcano: Oregon Department of Geology and Mineral Industries Special Paper 8.

Wise, William, R., 1968, Geology of Mt. Hood Volcano: Andesite Conference Guidebook, Oregon Department of Geology and Mineral Industries Bulletin 62.

Wise, William R., 1969, Geology and Petrology of the Mt. Hood Area: A Study of High Cascade Volcanism: Geological Survey of America Bulletin, v. 80 . 
Blank

$-104-$ 
ACTIVE FAULT. A fault along which measurable displacement has occurred in comparatively recent geologic time (usually late Quaternary or Holocene). Less than .5 million years.

ACTIVE SEISMIC METHOD. Uses explosives to produce acoustic waves which are reflected and refracted through the earth and recorded by arrays of sensitive pick-ups (geophones); geologic structure is inferred from the recorded signals.

ALEUTIAN ISLANDS. A young volcanic island chain that extends westsouthwest off the south western tip of Alaska.

ANDESITE. A fine-grained igneous rock with no quartz or orthoclase, composed of about $75 \%$ plagioclase feldspars and $25 \%$ ferromagnesium silicates. Important as lavas, possibly derived by fractional crystallization from basaltic magma; widely characteristic of mountain making processes around the Pacific Ocean.

ANOMALY. 1: In geology, a local feature distinguishable in a geophysical, geochemical, or geobotanical measurement over a larger area. 2: a feature considered capable of being associated with commercially valuable deposits.

AQUICLUDE. An impermeable strata that acts as a barrier to the flow of ground water.

AQUIFER. A water bearing stratum of permeable rock, sand, or gravel.

ARTESIAN. Ground water that has sufficient hydrostatic head to rise above its aquifer, but which does not necessarily rise to or above the surface of the ground.

ARTESIAN WELL. A well that penetrates an aquifer containing water with sufficient pressure to rise above the local ground level.

AUGER. A drilling tool designed so that during the drilling operation, the cuttings are carried continuously to the top of the hole by helical grooves on a rotating drill pipe.

$\underline{B}$

BALNEOLOGY. Science of the healing qualities of baths, especially natural mineral waters; the therapeutic use of natural warm of mineral waters.

BASALT. Designates a volcanic rock low in silica, and rich in iron and magnesium. By far the most abundant of all types of lava in the earth's crust.

BASEMENT. Geologic basement is the highest surface beneath which sedimentary rocks are not found; i.e., igneous or metamorphic rock underlying sedimentary rocks. 
BED ROCK. A general term for the rock, usually solid, that underlies soil or other unconsolidated, superficial material.

BINARY CYCLE. In geothermal power-plant design, denotes the use of a heat exchanger to conduct heat from a geothermal brine to the working fluid (low-boiling point fluid such as isobutane) which drives a turbine.

BIPOLE-DIPOLE MAPPING. Electrical method of geophysical exploration. Current flow is established in the earth by using a pair of source electrodes; the electric field is determined by observing the voltage drop between two pairs of electrodes oriented approximately at right angles.

BLOWOUT. The sudden, often explosive escape of steam and perhaps hot water from a geothermal we 11; may be caused by improper drilling procedures or rupture of casing and well-head equipment.

BLOWOUT PREVENTER. A device used to prevent the escape of 011 , water, or gas when a pressurized pocket is penetrated by a dril1.

BOILING POINT. The temperature at which the vapor pressure of a liquid is equal to the pressure of the atmosphere on the liquid.

BOREHOLE. A hole drilled into the earth, often to a great depth, as a prospective oil well or for exploratory purposes.

BRINES. A highly saline solution. A solution containing appreciable amounts of $\mathrm{NaCl}$ and other salts.

BRITISH THERMAL UNITS (BTU):: The quantity of heat required to raise the temperature of $11 \mathrm{~b}$. of water $1^{\circ} \mathrm{F}$ at or near its point of maximum density; a unit of energy equal to .000298 kilowatt-hour, or 252.0 calories.

$\underline{C}$

CALORIE. The amount of heat needed to raise the temperature of one gram of water from $3.5^{\circ}$ to $4.5^{\circ} \mathrm{C}$.

CAP ROCK. A comparatively impervious stratum that prevents the circulation of heat or fluids.

CASCADES. A volcanic mountain chain running north south and extending from central northern California to central southern British Columbia.

CASING. A heavy pipe or tubing of varying diameter which is driven or lowered into a borehole during or after drilling in order to support the sides of the hole and thus prevent caving and loss of produced fluids which could contaminate near-surface potable water Also used to prevent unwanted gas, water, or other fluid from entering the hole from other than the producing aquifer.

CELSIUS. A thermometric scale in whcih the melting point of ice is zero and the bojling point of water is 100 degrees above zero $\left({ }^{\circ} \mathrm{C}=\left({ }^{\circ} \mathrm{F}-32\right) 5 / 9\right)$. 
CHEMICAL GEOTHERMOMETER. A technique used in exploration to assess the temperature characteristics of a geothermal reservoir. Most widely used geothermometers are the $\mathrm{SiO}_{2}$ content and $\mathrm{Na}, \mathrm{Ca}$, and $\mathrm{K}$ ratios measured in water samples.

COLLAR (DRILL). The mouth or open end of a drill hole; the rock surrounding the mouth of a borehole.

CONDENSER. A device for reducing gases or vapors to liquid or solid form.

CONDUCTION. In thermodynamics, the transference of heat through a medium or body driven by a temperature gradient and involving no macroscopic particle motion.

CONNATE WATER. Water trapped in the pore spaces of sediments at the time of deposition.

CONTOUR MAP. A map showing the configuration of the surface by means of lines connecting the points that have the same elevation.

CONVECTION. A process of mass movement in a fluid medium (gas, liquid, or plastic solid), in which cooler, denser material settles, and lighter, hotter material rises, causing vertical, near-circular flow. The process thus moves both the medium and the heat.

CORE HOLE. Any hole that is made for the purpose of obtaining core samples, e.g. a well drilled for information only, or a borehole made by a core drill.

CORROSION. A process in which a solid (usually a metal) is eaten away by a fluid (usually an acid).

CRUST. The outermost layer of the earth, composed of relatively cool, brittle, low-density rocks (compared with the mantle), and ranging in thickness from 5 kilometers (beneath the ocean floors) to 30 to 50 kilometers (under continents).

D

DARCY. A unit of permeability. The unit of the darcy is $\mathrm{g}-\mathrm{cm} / \mathrm{atm}-\mathrm{s}$ since in Darcy's equation, length is in $\mathrm{cm}$, pressure in atmospheres, mass in grams, fluid flow in $\mathrm{cm}^{3} / \mathrm{s}$, and viscosity in centipoise $=0.01$ dyne-s $/ \mathrm{cm}^{2}=0.01 \mathrm{grm} / \mathrm{cm}-\mathrm{s}$.

DEGREE DAYS. The difference between the daily average temperature ( ${ }^{\circ} \mathrm{F}$ ) and some arbitrary temperature such as $65^{\circ} \mathrm{F}$. Degree days are used to indicate patterns of diviation from a given temperature standard.

DIKE. A tabular body of igneous rock that cuts across the structure of adjacent rocks or cuts massive rock. Although most dikes result from the intrusion of magma, some are the result of metamorphic processes.

DIPOLE-DIPOLE. A type of resistivity survey in which the transmitting and receiving dipoles are of the same length (i.e., electrodes 
spaced equally and wherein the receiving-dipole stations are located at regular intervals along a line perpendicular to and bisecting the transmitting dipole.

DRILLING MUD. A suspension, generally aqueous, used in rotary drilling. It is pumped downward through drill pipe to seal off porous zones and to counter-balance the pressure of $0 i 1$, gas, and water. It also serves to cool the drilling bit and to bring cuttings to the surface.

DRILL PIPE. Pipe to which the bit is attached and which is rotated by a drill. Drilling fluid circulates through the pipe.

DRY ROCK. Rocks beneath the earth's surface that do not have meteoric or juvenile water supplied to them by an aquifer or any other source.

DRY STEAM. Steam without entrained liquid water, i.e., pure steam.

$\underline{E}$

EFFICIENCY. The ratio of the useful energy output of a machine or other energy-converting plant to the energy input.

EFFLUENT. 1: Something that flows out, as an outflowing branch of a main stream or lake. 2: Waste material (as smoke, liquid industrial refuse, or sewage) discharged into the environment, especially when serving as a pollutant.

ENERGY. The ability to do work, expressed in Kilowatt Hours, British thermal units, or calories.

EPICENTER. The point on the earth's surface directly above the origin of an earthquake.

EQUILIBRIUM. Equilibrium exists in any system when the physical properties of elements within the system remain unchanged through time (steady-state).

EXTRUSIVE. Igneous rock that has been ejected onto the surface of the earth.

$\underline{\mathbf{F}}$

FAHRENHEIT. A thermometric scale in which the melting point of ice is 32 degrees above zero and the boiling point of water is 212 degrees above zero $\left({ }^{\circ} \mathrm{F}=9 / 5{ }^{\circ} \mathrm{C}+32\right)$.

FAULT. A fracture or fracture zone in the earth's crust along which there has been displacement of the sides relative to one another parallel to the fracture.

FISSURE. An extensive crack, break, or fracture in rock. A mere joint or crack persisting only for a few inches or even a few feet is not usually termed a fissure by geologists or miners, although in a strict physical sense, it is. 
FLASHED STEAM. Steam produced by the boiling of superheated water upon release of confining pressure.

FOLD. A curve or bend of a planar structure such as rock strata or bedding planes.

FOSSIL FUEL. A deposit of organic material containing stored solar energy that can be used as fuel. The most important are coal, natural gas and petroleum.

FRACTURE POROSITY. Porosity resulting from the presence of openings produced by the breaking or shattering of an otherwise less pervious rock.

FREE ENERGY. That portion of the energy of a system that is the maximum available for doing work.

FUMAROLE. A hole, vent, or geyser which emits steam or gaseous vapor; found usually in volcanic areas.

$\underline{G}$

GEOCHEMISTRY. Chemistry of the earth; applied geochemistry uses chemical analyses to find economic resources, including minerals and geothermal fluids.

GEOLOGIC MAP. A map showing surface distribution of rock varieties, age relationships, and structural features.

GEOLOGY. A study of the planet earth; its composition, structure, processes, and history.

GEOPHYSICS. Physics of the earth; applied geophysics uses various methods of measuring physical characteristics of the earth's crust to locate economic resources.

GEOTHERMAL. Of or relating to the earth's natural heat.

GEOTHERMAL ENERGY. The internal energy of the earth, available to man as heated rocks or water.

GEOTHERMAL GRADIENT. The rate of increase of temperature in the earth with depth. The gradient near the surface of the earth varies from place to place, depending on the heat flow in the region and on the thermal conductivity of the rock. Approximate average geothermal gradient in the earth's crust is about $25^{\circ} \mathrm{C} / \mathrm{km}$.

GEOTHERMOMETER. A geochemical method which uses ground water chemistry to estimate the temperature of a geothermal reservoir.

GEYSER. A spring that throws forth intermittent jets of heated water or steam. The heated water results from the contact of ground water with hot rock.

GRABEN. An elongate, relatively depressed crustal unit or block that is bounded by faults on its long sides. It is a structural form that may or may not have topographic expression. 
GRAVITY SURVEY. Measurements of the gravitational field at a series of different locations over an area of interest. Interpretation of data may lead to the location of faults, folds and intrusive bodies.

$\underline{H}$

HEAT EXCHANGER. A device for transferring heat from one fluid to another. "The fluids are usually (but not necessarily) separated by conducting walls.

HEAT FLOW. Dissipation of heat coming from within the earth by conduction (i.e., heat flow from a magma into its surroundings or heat generated radiation from the breakdown of radioactive elements) measured at the earth's surface; the average is about $1.5 \times 10^{6} \mathrm{cal} / \mathrm{cm}^{2} / \mathrm{s}$.

HEAT FLOW UNIT. One heat flow unit is equal to $1 \times 10^{6} \mathrm{cal} / \mathrm{cm}^{2} / \mathrm{s}$. or ca $41.85 \mathrm{milliwatts} / \mathrm{m}^{2} / \mathrm{s}$.

HEAT PUMP. A device which, by the consumption of work or heat, effects the transport of heat between a lower temperature and a higher temperature. In conventional usage; the term is usually limited to a device whose useful output is heat.

HIGH-TEMPERATURE RESERVOIRS. Reservoirs with base temperatures greater than $150^{\circ} \mathrm{C}$.

HORST. 1:. A mass of rock that is limited by faults and which was uplifted but may or may not have topographic expression. 2: A block of the earth's crust separated by faults from adjacent relatively depressed blocks.

HOT WATER SYSTEM. A system that is dominated by a circulating liquid that transfers most of the heat and largely controls subsurface pressures, and is often characterized by hot springs that discharge at the surface.

HYBRID. An energy source used in conjunction with another energy source. Example: Geothermal used with wood waste or coal to produce electricity.

HYDROLOGY. The science that deals with the properties, distribution, and circulation of continental water on the surface, in the soil and underlying rocks, and in the atmosphere.

HYDROSTATIC LEVEL. The level at which water rises in a well due to the water pressure in the aquifer.

HYDROTHERMAL. An adjective applied to heated or hot aqueous-rich solutions, to the processes in which they are involved, and to the rocks, ore deposits, and alteration products produced by them. Hydrothermal solutions are of diverse sources, including magmatic, meteoric, and connate waters.

HYDROTHERMAL ALTERATION. The phase changes resuiting from the interaction of hydrothermal fluids with pre-existing solid phases. Included are the chemical and mineralogical changes in rocks and soils brought about by the addition or removal of materials through the medium of hydrothermal fluids. 
IGNEOUS ROCK. Rock formed from a melt or magma by cooling and solidification. If the solidification occurred at depth, the rock is called "plutonic," if formed from magma erupted onto the surface, called "volcanic."

INTERMEDIATE TEMPERATURE RESERVOIR. A reservoir in which the fluid temperature is between $90^{\circ} \mathrm{C}$ and $150^{\circ} \mathrm{C}$.

INTRUSIVE. Having been forced. while in a fluid state into or between other rocks, but solidifying before reaching the surface. Said of plutonic igneous rocks and contrasted with extrusive.

ISOTOPE. A subspecies of an element having a slightly different molecular weight due to differences in the number of neutrons in the molecular structure.

$\underline{\mathrm{J}}$

JUVENILE WATER. Water that is drived from the interior of the earth and has not previously existed as atmospheric or surface water.

$\underline{K}$

KNOWN GEOTHERMAL RESOURCE AREA (KGRA). An area which the Mineral Land Classification Committee of the United States Geological Survey has designated as potentially valuable for production of geothermal energy; KGRAs are essentially confined to public domain lands (under BLM administration), and their establishment is based on both scientific and competitive-interest criteria.

KILOWATT-HOUR ( $k$ whr). The energy represented by one kilowatt of power consumed for a period of one hour; equals $3,415 \mathrm{Btu}$ and/or $8.6 \times 10^{5}$ calories; in the U.S., the installed generating capacity supplies approximately 1 'kwhr of energy per person per hour.

$\underline{L}$

LIFE CYCLE COSTS. A summation of the acquisition, operation, maintenance, and disposal costs of an item from the date of purchase to the date of disposal.

LOW-TEMPERATURE RESERVOIR. Geothermal reservoirs with base temperatures less than $90^{\circ} \mathrm{C}$.

$\underline{M}$

MAGMATIC WATER. Water that exists in or is derived from molten igneous rock or magma.

MEGAWATT. One thousand kilowatts. $M W_{e}=$ electrical capacity in megawatts. $M W_{t}=$ thermal power in megawatts. 
METEORIC WATER. Rain water entering soil or rock and percolating downward.

METES \& BOUNDS. The boundaries or limits of a tract of land in which the bearing and length of boundary lines may be described by reference to local natural or artificial monuments such as a stream, ditch or road.

MICROEARTHQUAKE. A small earthquake, with Richter magnitude less than 3 , and which is normally not felt.

MUD VOLCANO. A cone-shaped mound with a maximum height of 250 feet built around a spring by mud brought to the surface by slowly escaping natural gas.

N

Na-K-Ca GEOTHERMOMETER. A method of calculating the temperature of a geothermal reservoir from the relative concentrations of $\mathrm{Na}$ (sodium), $\mathrm{K}$ (potassium), and Ca (calcium) present in a geothermal fluid sample; it is based upon empirical data on the equilibrium solubilities of those ions as a function of temperature.

$\underline{P}$

PASSIVE SEISMIC METHOD. An exploration technique relying on naturally occurring seismic waves (e.g. from earthquakes).

PAYBACK. A method of determining the period of time required to recover the capital invested in a project.

PERMAFROST. Permanently frozen subsoil.

PERMEABILITY. The permeability of a rock is its capacity for transmitting a fluid. Degree of permeability depends upon the size and shape of the pores, the size and shape of their interconnections, and the extent of the latter. It is measured by the rate at which a fluid of standard viscosity can move a given distance through a given interval of time. The unit of permeability is the darcy.

PLATE TECTONICS. A study of the movement of the plates that make up the earth's crust. The boundaries of the continuously moving plates can be seen as ocean trenches, volcanic mountain chains such as the Alleutian Islands and Cascade Mountains, mid ocean ridges, and transform faults such as the San Andreas Fault.

POROSITY. The ratio of the aggregate volume of pore spaces in a rock or soil to its total volume; usually stated as a percent.

POWER. Rate at which work is done. Watts $(W), B t u / h r, c a l / s e c$.

PPB. Parts: per billion; by weight.

PPM. Parts per million, by weight. 
PRESENT VALUE-PRESENT WORTH. The value at present (time zero) of a projected series of costs or revenues discounted at some interest rate (cost of capital or required return on investment) from the time they occur to time zero.

$\underline{Q}$

QUAD. Equal to $10^{15} \mathrm{Btu}$.

$\underline{\mathrm{R}}$

RECONNAISSANCE. The initial investigation of a large area in order to locate prospects or targets.

REINJECTION. The injection of produced geothermal fluids back into the reservoir from which they came through disposal wells.

RESERVOIR. A natural underground container of liquids, such as oil, water, or gases. In general, such reservoirs were formed by local deformation of strata, changes of porosity, faulting, or intrusions.

RESISTIVITY. Electrical resistance per unit length in any material; this varies widely with rock type, porosity, temperature and salinity; usually expressed in OHM-meters.

RESISTIVITY METHOD. Observation of electric potential and current distribution at the earth's surface intended to detect subsurface variations in resistivity that may be related to geology, ground water temperature and quality, or porosity.

\section{$\underline{\mathrm{S}}$}

SALINE. A term used to designate waters containing high concentrations of dissolved salts, such as sea water.

SALINITY. A measure of the total dissolved salts per volume of water; for comparision, sea water has a salinity of ca 35,000 ppm.

SATURATED VAPOR. A vapor that is in equilibrium with its liquid at a given temperature and pressure.

SCALING. Precipitation and deposition of dissolved solids in pipes or other containers (of geothermal or other fluids).

SEISMIC. Pertaining to an earthquake or earth vibration, including those that are artifically induced:

SINTER. A chemical sedimentary rock that forms by precipitation from hot or cold mineral waters of springs," lakes, or streams. 
SILICA GEOTHERMOMETER. A method of calculating the temperature of : a geothermal reservoir from the concentration of $\mathrm{SiO}_{2}$ in a geothermal fluid sample; it is based upon empirical data on the equilibrium solubilities of quartz, chalcedony, and other silicate species as a function of temperature.

SODA SPRING. An alkali spring whose waters contain a high content of dissolved sodium salts, chiefly sodium carbonate.:

SOLUBILITY. The equilibrium concentration of a salt in a solution which is dependent upon pressure and temperature.

SPACE HEATING. The process of supplying the required heat for the physical comfort of human beings in houses, offices, or enclosed industrial plants. The heat required for a typical domestic dwelling on an average winter day in the U.S. is about $27,000 \mathrm{BTU} / \mathrm{hr}$. or $7.8 \mathrm{~kW}$.

SPECIFIC HEAT. The quantity of heat necessary to raise the temperature of 1 gram of a given substance $1^{\circ} \mathrm{C}$.

STEAM. 1: The water is converted to steam when heated to the boiling point. 2: The pure gaseous phase of $\mathrm{H}_{2} \mathrm{O}$.

STRATUM. 1: A section of a formation that consists of approximately the same kind of rock material throughout. 2: A single sedimentary bed or layer, regardless of thickness.

SUBSIDENCE. 1: A sinking of a large part of the earth's crust. 2: Movement in which there is no free side and surface material is displaced vertically downward with little or no horizontal component.

SUPERHEATED. 1: A process of adding more heat than is necessary to complete a given phase change. 2: In magmas, the accumulation of more heat than is necessary to cause essentially complete melting, in such cases the increase in temperature of the liquid above the liquidus temperature for any major mineral components is called the superheat.

SUPERSATURATED. A solution that contains more of the solute than is normally present when equilibrium is established between the saturated solution and undissolved solute.

I

TECTONIC. Refers to those processes by which rocks of the crust and upper mantle are deformed (faulted, fractured, folded).

TECTONIC MAP. A map which shows major structural

features produced by uplift, downwarp, or faulting, together with the major lineations within such features.

TEMPERATURE-GRADIENT SURVEY. The study of precisely measured temperatures at successive depths in a drill hole in order to determine the rate of temperature increase with depth.

THERMAL GRADIENT. Pertains to the rate of increase or decrease in temperature with distance in a specified direction. 
THERMAL SPRING. A spring displaying waters significantly higher than mean annual temperature for that area.

THERMO SYPHONING. The natural convective movement of hot water in heat exchangers.

TILTMETER. 1: A device for observing surface disturbances on a bowl of mercury, employed in an attempt to predict earthquakes. 2: An instrument used to measure displacement of the ground surface from the horizontal.

TON OF REFRIGERATION. The heat of fusion of one ton (more precisely 200.91 lbs.) of water. One ton of refrigeration $=288.000 \mathrm{Btu}=3.035 \mathrm{x}$ $108 \mathrm{~J}$.

TRAVERTINE. Calcium carbonate $\left(\mathrm{CaCO}_{3}\right)$ of light color deposited from solution in ground and surface waters. Extremely porous or cellular varieties are known as calcareous tufa, calcareous sinter, or spring deposit. Travertine forms the stalactites and stalagmites of limestone caves and the filling of some veins and hot spring conduits.

TUFA. A porous or cellular variety of travertine.

TUNDRA. The treeless plains of arctic regions and their associated unique ecosystems.

$\underline{V}$

VAPOR-DOMINATED. A geothermal system in which pressures are controlled by vapor rather than by liquid.

VOLCANISM. Natural processes resulting in the formation, movement, eruption, and crystallization of magmas, forming volcanoes and volcanic rocks.

$\underline{W}$

WARM SPRING. A thermal spring whose temperature is appreciably above the local mean atmospheric temperature, but below that of the human body. Cf: HOT SPRING.

WATER TABLE. That surface of a body of unconfined ground water at which the pressure is equal to that of the atmosphere.

WATT. Unit of electric energy equal to $3.4 \mathrm{Btu} /$ hour.

WORK. The product of the force acting upon a body and the distance through which it moves. Work = force $x$ distance. The result is kinetic or potential energy. 